\title{
Characterizing Textural Attributes of Rainbow Trout, Oncorhynchus mykiss, Fillets as Affected by Age, Sterility, and Storage Regimen
}

\author{
Aunchalee Aussanasuwannakul \\ West Virginia University
}

Follow this and additional works at: https://researchrepository.wvu.edu/etd

\section{Recommended Citation}

Aussanasuwannakul, Aunchalee, "Characterizing Textural Attributes of Rainbow Trout, Oncorhynchus mykiss, Fillets as Affected by Age, Sterility, and Storage Regimen" (2011). Graduate Theses, Dissertations, and Problem Reports. 3391.

https://researchrepository.wvu.edu/etd/3391

This Dissertation is protected by copyright and/or related rights. It has been brought to you by the The Research Repository @ WVU with permission from the rights-holder(s). You are free to use this Dissertation in any way that is permitted by the copyright and related rights legislation that applies to your use. For other uses you must obtain permission from the rights-holder(s) directly, unless additional rights are indicated by a Creative Commons license in the record and/ or on the work itself. This Dissertation has been accepted for inclusion in WVU Graduate Theses, Dissertations, and Problem Reports collection by an authorized administrator of The Research Repository @ WVU.

For more information, please contact researchrepository@mail.wvu.edu. 


\title{
Characterizing Textural Attributes of Rainbow Trout, Oncorhynchus mykiss, Fillets as Affected by Age, Sterility, and Storage Regimen
}

\author{
Aunchalee Aussanasuwannakul \\ Dissertation submitted to the \\ Davis College of Agriculture, Natural Resources and Design \\ at West Virginia University \\ in partial fulfillment of the requirements \\ for the degree of \\ Doctor of Philosophy \\ in \\ Animal and Food Sciences \\ P. Brett Kenney, Ph.D., Chair \\ Jianbo Yao, Ph.D. \\ Mohamed Salem, Ph.D. \\ Kristen Matak, Ph.D. \\ Ming Pei, Ph.D.
}

Division of Animal and Nutritional Sciences

Morgantown, West Virginia

2011

Keywords: Rainbow trout; Texture; Instrumental analysis; Sensory analysis; Sexual maturation; Thermal denaturation; Thermal gelation; Collagen

Copyright 2011 Aunchalee Aussanasuwannakul 


\section{ABSTRACT \\ Characterizing Textural Attributes of Rainbow Trout, Oncorhynchus mykiss, Fillets as Affected by Age, Sterility, and Storage Regimen}

\section{Aunchalee Aussanasuwannakul}

Trout fillets, subjected to refrigeration $\left(4^{\circ} \mathrm{C} ; 3\right.$ or $\left.7 \mathrm{~d}\right)$ by frozen storage $\left(-25^{\circ} \mathrm{C} ; 0\right.$ or $\left.30 \mathrm{~d}\right)$ combinations, were cooked; texture, determined by a novel, variable-blade (VB) attachment, was compared with a widely-used Allo-Kramer shear (AK) attachment to determined its sensitivity in detecting variation in fillet texture. Instrumental texture was related to sensory measurements to determine attachments' accuracy in assessing cooked fillet texture. Weight of raw fillets decreased after 30-d frozen storage. Fillet weight further decreased after cooking. Moisture content decreased while fat content remained constant. The AK attachment detected differences in energy of shear, which decreased after 30-d frozen storage. Shear force increased after cooking and could be detected by VB attachment. The VB attachment, in a perpendicular direction, demonstrated the effect of shear direction; force determined by this configuration correlated with sensory hardness and cook loss.

Fertile and sterile fish were chosen as a model to describe key contributors to fillet texture. Two sets of 60 diploid ( $2 \mathrm{~N}$; fertile) and triploid ( $3 \mathrm{~N}$; sterile) females were harvested at 6 age endpoints $(16,18,20,21,21$, and $24 \mathrm{mo})$. From November 2008 (20 mo) to January 2009 (21 $\mathrm{mo}$ ), GSI of $2 \mathrm{~N}$ females increased substantially and their growth were at equal rate to those of $3 \mathrm{~N}$ females. By November 2008, 2N females had a lower muscle fat content and higher moisture content than $3 \mathrm{~N}$ females. Shear force negatively correlated with fillet fat content. Regardless of ploidy, raw fillets were softer between November 2008 and January 2009. Alkaline-insoluble hydroxyproline (a-i HYP) content of 2N muscle increased substantially in March 2009 (24 mo), and this response was consistent with increased energy of shear $\left(\mathrm{g}^{*} \mathrm{~mm}\right)$. In March 2009, denaturation peaks $\left(\mathrm{T}_{\max }\right)$ of actin from $2 \mathrm{~N}$ females were higher than those observed in $3 \mathrm{~N}$ females $\left(78.17 \mathrm{v} .77 .27^{\circ} \mathrm{C}\right)$. Muscles of $2 \mathrm{~N}$ fish were more elastic than those of $3 \mathrm{~N}$ fish in a thermal scan ranged from $35-40^{\circ} \mathrm{C}$. At temperatures greater than or equal to $45^{\circ} \mathrm{C}$, muscle from younger $(16$ mo) fish was more elastic than older fish (18-24 mo). Lipid accumulation, observed primarily in $3 \mathrm{~N}$ females, may lubricate and soften muscle fibers, and protect them from losing functionality at spawning when animals are on a high plane of nutrition.

Lastly, the VB was compared to the AK attachment for 1) its sensitivity in discriminating texture variation and 2) its predictability in relating texture parameters to alkaline insoluble HYP content. In the maturation study, the VB detected effect of age endpoint on cooked texture; minimum firmness was observed in January compared with December and March. In the storage regimen study, regimen*cooking state affected fillet texture; AK detected effect of 30-d frozen storage on raw texture; whereas, VB detected this effect after cooking. In both studies, VB texture was not correlated with collagen insolubility; the finding may have been due to limited sample size and range of variation in texture and fillet composition. 


\section{ACKNOWLEDGEMENTS}

I would like to express my sincerest gratitude to Dr. P. Brett Kenney, my major advisor, for giving me an opportunity to develop professionally. I am thankful for him trusting my decisions, giving me encouragement and careful thought, and helping me overcome all obstacles.

I would like to thank Dr. Jianbo Yao, Dr. Mohamed Salem, Dr. Kristen Matak, and Dr. Ming Pei, my committee members, for their constructive criticisms and great support.

For taking and accomplishing Ph.D. abroad, I feel a deep sense of gratitude:

- to Ms. Susan Slider for being part of every aspect of my dissertation work and lending me her wisdom. I especially thank her for providing invaluable friendship, steady working environment, and a sense of family.

- to Ms. Meghan Manor for her friendship and contribution to the project.

- to Ms. Johni-Ann Sims for her assistance with sample preparation, proximate analysis, and a lot more in the lab.

- to Dr. Gregory Weber at the National Center for Cool and Cold Water Aquaculture, USDA Agricultural Research Service for his expertise in fish reproduction and growth.

- to Dr. Robert Brannan at School of Applied Health Sciences and Wellness, Ohio University, for his expertise and availing facility for sensory analysis.

- to faculties, staffs, and fellow graduate and undergraduate students of the Division of Animal and Nutritional Sciences, Davis College of Agriculture, Natural Resources and Design, for their warm welcome and support.

- to Thai Student Organization at West Virginia University for their support and encouragement. 
I gratefully acknowledge the support of National Research Initiative Competitive Grants Program, US Department of Agriculture.

I would like to thank my mother, Mrs. Feem Aussanasuwannakul, my sister, Ms. Orapan Aussanasuwannakul, and my brother, Mr. Sasipath Aussanasuwannakul for their love, support, and always being there whenever I need them.

I am proud to have been a Ph.D. student at West Virginia University and very grateful to people who help me reach my goals. To those who have not been mentioned, I thank you all! 


\section{TABLE OF CONTENTS}

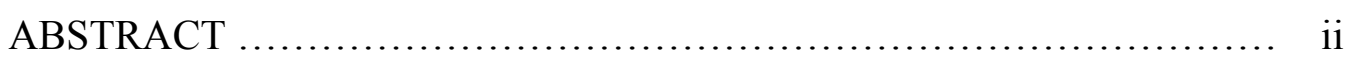

ACKNOWLEDGEMENTS ....................................... iii

TABLE OF CONTENTS $\ldots \ldots \ldots \ldots \ldots \ldots \ldots \ldots \ldots \ldots \ldots \ldots \ldots \ldots \ldots \ldots \ldots \ldots$

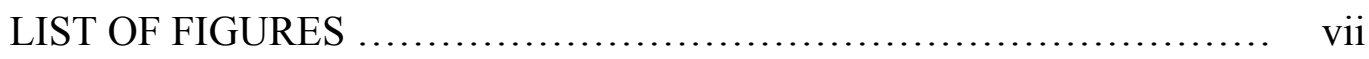

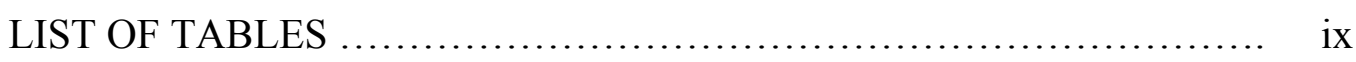

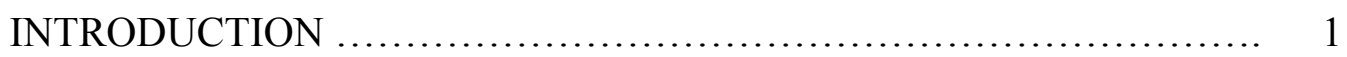

\section{LITERATURE REVIEW}

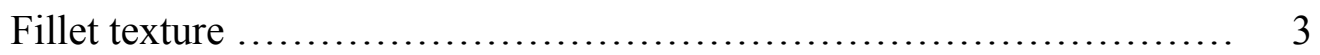

Effect of growth and sexual maturation .......................... 4

Effect of storage regimen ..................................... 5

Effect of cooking ........................................... 6

Collagen contribution to fillet texture ............................. 6

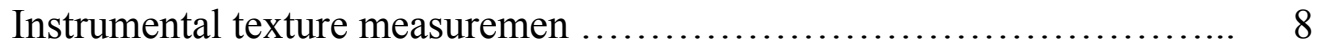

References .................................................. 11

CHAPTER 1 Relating instrumental texture, determined by variable-blade and Allo-Kramer shear attachments, to sensory analysis of rainbow trout, Oncorhynchus mykiss, fillets

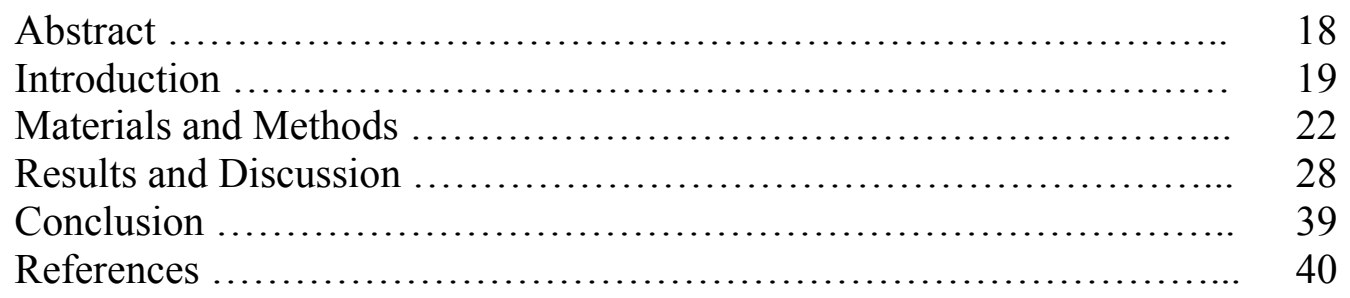

CHAPTER 2 Effect of sexual maturation on growth, fillet composition, and texture of female rainbow trout (Oncorhynchus mykiss) on a high nutritional plane

Abstract ........................................................ 56

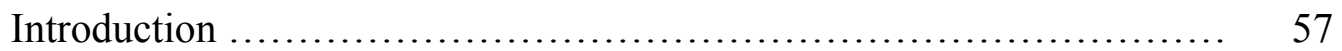

Materials and Methods ........................................... 60

Results ..................................................... 66 


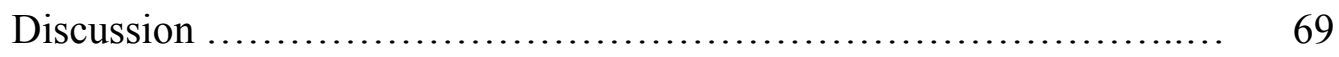

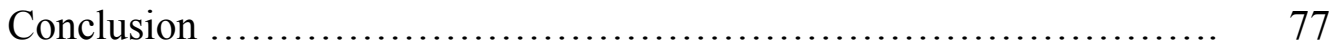

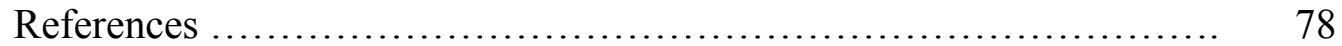

CHAPTER 3 Effect of sexual maturation on thermal stability, viscoelastic properties, and texture of rainbow trout, Oncorhynchus mykiss, fillet

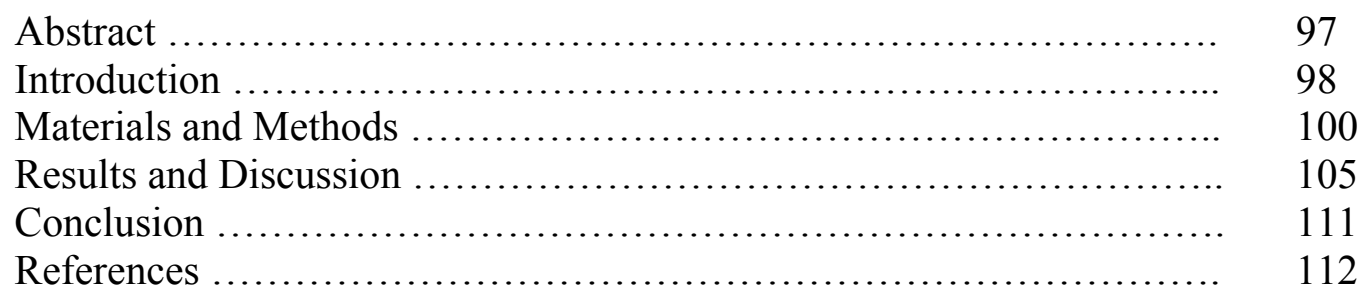

CHAPTER 4 Comparison of variable-blade to Allo-Kramer Shear method in assessing rainbow trout (Oncorhynchus mykiss) fillet firmness

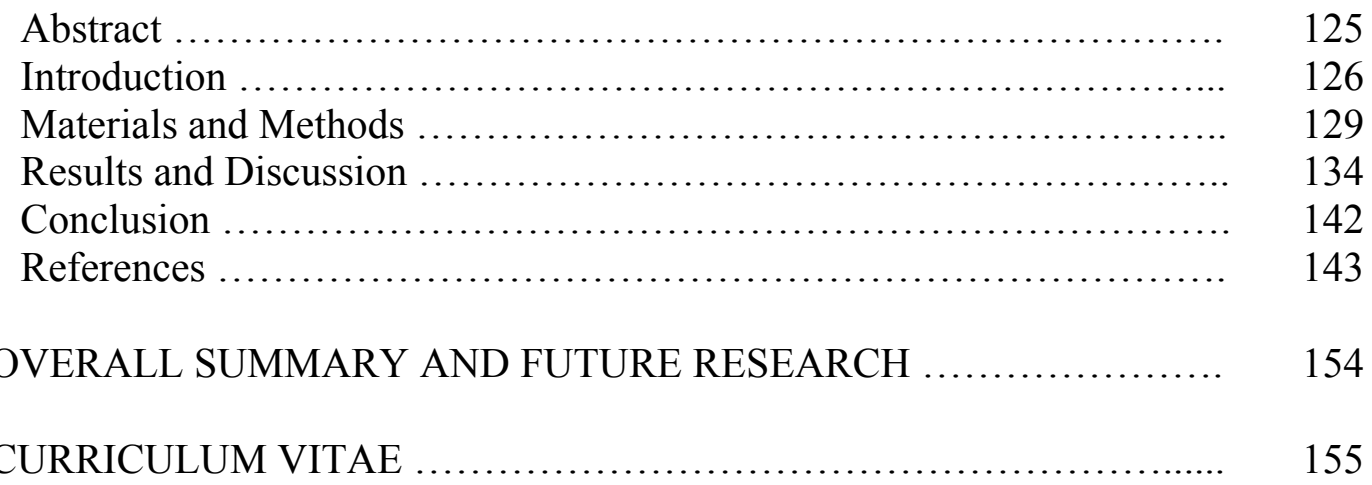




\section{LIST OF FIGURES}

\section{CHAPTER 1}

Figure 1 Deformation of cooked fillet by Allo-Kramer shear attachment

Figure 2 Force-deformation curves generated by Allo-Kramer and variable blade attachment ............................

Figure 3 Variable-blade attachment and a top view of cooked fillet after a perpendicular shear

Figure 4 Processing loss (\%) for fillets stored under different

storage regimens

Figure 5 Maximum force $(\mathrm{g} / \mathrm{g})$ determined by variable blade

Figure 6 Area or energy of shear $\left(\mathrm{g}^{*} \mathrm{~mm}\right)$ determined by Allo-Kramer attachment

Figure $7 \quad$ Loading plot of five sensory attributes on principal component axes

\section{CHAPTER 2}

Figure $1 \quad$ Whole body weight $(\mathrm{g})$ of individually tagged fish as a function of age endpoint

Figure 2 Specific growth rate (SGR) of individually tagged fish as a function of age endpoint

Figure 3 Gonadosomatic index (GSI) of random fish as a function of age endpoint

Figure 4 Viscera of whole body weight (WBW; \%) as a function of age endpoint

Figure 5 Separable muscle of whole body weight (WBW; \%) as a function of ploidy

Figure 6 Separable muscle of empty body weight (EBW; \%) as a function of age endpoint 
Figure 7 Abdominal wall thickness $(\mathrm{cm})$ as a function of age endpoint

Figure $8 \quad$ Fat and moisture content (\%) of raw fillets as a function of age endpoint

Figure 9 Redness (a*) value of raw fillet surface as a function of age endpoint

Figure 10 Alkaline-insoluble (a-i) hydroxyproline (HYP) content $(\mu \mathrm{mole} / \mathrm{g})$ of raw fillets as a function of age endpoint .......

Figure 11 Shear force $(\mathrm{g} / \mathrm{g})$ of raw fillets as a function of age endpoint

Figure 12 Area or energy of shear $\left(\mathrm{g}^{*} \mathrm{~mm}\right)$ of raw fillets as a function of age endpoint

\section{CHAPTER 3}

Figure 1 Endothermic heat flow of whole muscle sample as a function of scanning temperature

Figure 2 Fat content (\%) of raw fillets at six age endpoints

Figure 3 Cook yield (CY, \%) and moisture content (\%) of raw fillets at six age endpoints

Figure 4 Change in storage modulus (G', Pa) and loss tangent $(\tan \delta)$ of $2 \mathrm{~N}$ muscle paste during thermal gelation

Figure 5 Change in storage modulus (G', Pa) and loss tangent $(\tan \delta)$ of $3 \mathrm{~N}$ muscle paste during thermal gelation .........

Figure 6 Shear force $(\mathrm{g} / \mathrm{g})$ determined by Allo-Kramer shear attachment for raw and cooked fillet at six age endpoints ...

\section{CHAPTER 4}

Figure 1 The relationship between alkaline-insoluble hydroxyproline (a-i HYP) content and shear force of raw fillet determined by Allo-Kramer shear attachment (AK)

Figure 2 The relationship between alkaline-insoluble hydroxyproline (a-i HYP) content and energy of shear of raw fillet 


\section{LIST OF TABLES}

\section{CHAPTER 1}

Table 1 Description and anchored references of

sensory attributes generated by descriptive analysis

of trout fillets subjected to different storage regimens

Table 2 Mean $\mathrm{pH}$, moisture, and fat content of raw and cooked fillets

Table 3 Mean sensory attribute score of cooked fillets received different storage regimens

Table 4 Pearson correlation coefficient (r) between instrumental texture measurements and processing losses and sensory attribute scores of cooked fillets

\section{CHAPTER 3}

Table 1 Onset melting temperature $\left(\mathrm{T}_{\mathrm{m}}\right)$, temperature at the maximum heat flow $\left(\mathrm{T}_{\max }\right)$, and enthalpy of denaturation $(\Delta \mathrm{H})$ of whole muscle from diploid ( $2 \mathrm{~N}$; fertile) and triploid ( $3 \mathrm{~N}$; sterile) trout females harvested at three ages

Table 2 Elastic modulus (G') and $\tan \delta\left(\mathrm{G}^{\prime} / \mathrm{G}^{\prime}\right)$ at selected range of temperature sweep for muscle paste as affected by ploidy and ages endpoints

\section{CHAPTER 4}

Table 1 Comparison of features of variable-blade and Allo-Kramer shear method for testing fillet firmness using the TA.HDi Texture Analyzer

Table 2 Texture and hydroxyproline content (HYP; $\mu$ mole/g) of trout fillet from females harvested at three ages .......

Table 3 Texture and hydroxyproline content (HYP; $\mu$ mole/g) of raw and cooked fillets received different storage regimens 
Table 4 Pearson correlation coefficient (r) between alkaline-insoluble hydroxyproline (a-i HYP) content and instrumental texture parameter form variable blade (VB) and Allo-Kramer (AK) attachment ........................ 


\section{INTRODUCTION}

Instrumental texture measurement in fish relies on methods used in muscle of terrestrial species; this approach may be inaccurate because of their differences in muscle structure and protein stability. Fish muscle structure is more fragile than terrestrial, food animal muscle due to a less complex connective tissue hierarchy. Additionally, most commercially important fish including rainbow trout are poikilothermic animals and they live in a cold environment, the proteins of fish muscles have properties different from those of warm-blooded species. The widely-used Allo-Kramer (AK) attachment applies shear-compression force to cooked fillets and causes muscle flakes to slip past each other; the majority of the resistance to the applied force is accounted for by shearing a bulk of muscle fiber collected within the shear cell area. As a result, cooked texture could not be related to raw texture due to measurement of different texture components. Fillet texture, determined by AK, lacks repeatability; has low correlation with sensory texture, and gives incorrect interpretation of texture. The novel, variable blade (VB) attachment developed at West Virginia University in 2007 was designed to address the issues of blade thickness; $0.635-\mathrm{mm}$ thick blades cut completely through the muscle fiber. Twelve, removable and rotatable blades, arranged in two rows, provide flexibility for shear direction and cover a wider range of texture variation within a fillet sample. It is necessary to relate instrumental to sensory measurement because texture is an important sensory attribute; a high correlation with sensory measurement translates into high predictability of the instrumental method. Since changes in fillet composition and protein denaturation are the basis for variation in texture, sensitivity and accuracy of the instrumental method could be determined by its ability to detect these changes. Changes in fillet chemical composition and stability of muscle proteins that deteriorate fillet texture could be induced by sexual maturation. Therefore, a texture study, using fertile (2N) and 
sterile ( $3 \mathrm{~N})$ fish as a model, was chosen to describe key contributors to fillet texture which include collagen and myosin. Since collagen provides mechanical strength to fillet structure and shows variation with sexual maturation and cooking state, predictability of the VB attachment was determined by relating texture measurement to collagen content and its solubility.

Thus the work in this dissertation addressed: 1) developing a new shear attachment, 2) characterizing textural attributes of rainbow trout fillets from fertile and sterile females, and 3) characterizing collagen's contribution to fillet texture. In Chapter 1, differences in fillet texture were measured by the VB attachment and compared with AK and sensory analysis; fillets had been treated with four combinations of refrigeration and frozen storage. Chapter 2 and 3 aimed at relating growth to fillet texture; fillets were collected from fertile $(2 \mathrm{~N})$ and sterile $(3 \mathrm{~N})$ female rainbow trout as a model evaluating the effect of egg development (vitellogenesis) on fillet quality. In Chapter 3, thermal denaturation and viscoelastic characterization revealed changes in stability and gelling properties of muscle proteins that were related to changes in fillet texture. In chapter 4, VB and AK texture were related to collagen content and solubility; data were generated from stored fillets (Chapter 1) and fillets from diploid and triploid females (Chapter 2). 


\section{LITERATURE REVIEW}

\section{FILLET TEXTURE}

Fish fillet texture is a key criterion of flesh quality (Kiessling and others 2006) and consumer acceptability (Koteng 1992). Understanding texture attributes and methods for measuring texture is important to the aquatic food industry to address problems such as gaping and soft texture that cause difficulty in processing of fillets and poor eating quality (Ofstad and others 2006; Taylor and others 2002). Texture has been broadly defined by many authors (Szczesniak 1963; Jowitt 1974; Guinard and Mazzucchelli 1996; Bourne 2002); for example, Meilgaard and others (2006) define texture as the sensory manifestation of the structure or inner makeup of products in terms of their reaction to stress and tactile properties. This definition suggests that texture is a complex attribute involving multiple parameters, and thus it is of great importance to be aware of what physical parameter is being measured (Hyldig and Nielsen 2007). The finger method used in industry to evaluate firmness of raw fish is thought to be subjective (Sigurgisladottir and others 1997), whereas objective measurement using mechanical equipment is not reproducible because of the heterogeneity of fish fillets (Botta 1991; Reid and Durance 1992). Fish muscle differs from muscle of terrestrial food animals because of 1) less connective tissue, 2) less thermally stable muscle proteins characteristic of poikilothermic species compared to warmblooded species, and 3) its structural arrangement in the characteristic W-shaped segments called "myotomes" connected one to another by a thin sheath of connective tissue called "myocommata" (Foegeding and Lanier 1996). Since variation in fillet texture is explained by a wide range of factors including genetics (Periago and others 2005), slaughter method (Roth and others 2006), processing procedure (Birkeland and others 2004), and composition and tissue organization 
(Rasmussen 2001), suitable texture measurement depends on which of the key determinants are responsible for differences in texture (Hyldig and Nielsen 2007). Collagen content and its crosslink are the key contributors to variation in texture of raw flesh (Hatae and others 1986; Li and others 2005); whereas in cooked flesh, connective tissue is less important because of its low thermal stability. Cooked texture is influenced by muscle fiber size and inversely related to muscle fiber diameter (Hurling and others 1996). Changes in chemical composition and muscle structure, due to biological and processing factors, are the primary contributors to changes in fillet texture.

\section{EFFECT OF GROWTH AND SEXUAL MATURATION}

In fish, an increase in muscle mass is achieved during the posthatch growth phase, by hyperplasia (increase in muscle cell number) and hypertrophy (increase in size) (Bugeon and others 2010). Most fish become sexually mature when they reach a size characteristic of the species, and it is independent of age (Hyldig and Nielsen 2007). According to van Bohemen and others (1981), the annual reproductive cycle of rainbow trout (Salmo gairdneri) can be divided into four physiological periods: a previtellogenic period (March-April), a period of endogenous vitellogenesis (May-July), a period of exogenous vitellogenesis (August-December), and a period of ovulation and spawning (January-February). Vitellogenesis is the process of yolk formation via nutrients deposited in the oocyte, the female germ cell. Rainbow trout, during vitellogenesis, face a substantial energetic challenge that results in significant loss of muscle mass and mobilization of muscle proteins likely to support accumulation of yolk in developing ova.

Growth and maturation cause fluctuation in gross chemical composition and morphological structure of muscle and therefore texture quality (Kiessling and others 2006). In muscle, lipid 
shows the greatest variation and it is inversely related to moisture; whereas, protein is rather constant in most species. In farmed fish, several factors can be controlled, and the chemical composition may be predicted (Hyldig and Nielsen 2007). Fish use muscle tissue during gonad development due to insufficient dietary protein, causing soft fillets (Love 1988). Induction of triploidy has been used in fish to avoid problems associated with sexual maturation which include low muscle yield and deterioration of fillet texture (Piferrer and others 2009). Soft fillets, due to sexual maturation, are associated with changes in muscle protein content and activity of proteolytic enzymes (Toyohara and others 1991; Hagen and others 2008). Atrophying trout muscle tends to have reduced activities of enzymes of anaerobic respiration and protein biosynthesis (Salem and others 2010). Other than cathepsin, the proteolytic pathway of the ATP-dependent ubiquitinproteasome system contributes to fish muscle atrophy (Martin and others 2002; Salem and others 2006). Wang and others (2010) found that the MuRF gene family plays a role in muscle protein degradation of female rainbow trout. They investigated mRNA expression of MuRF genes of muscle from fertile $(2 \mathrm{~N})$ and sterile $(3 \mathrm{~N})$ female rainbow trout. They found that mRNA expression of three MuRF genes in 2N fishes significantly increased $(P<0.05)$ in December, which is the month preceding the spawning time, and subsequently decreased in January and March.

\section{EFFECT OF STORAGE REGIMEN}

Soft fillets are generally observed during chilled storage (Sato and others 1991; Ando and others 1992a, b; Færgemand and others 1995). During storage in ice some myofibrillar proteins degrade, but no changes occur in the structure of the contractile elements (Busconi and others 1989; Verrez-Bagnis 1997). During frozen storage, several mechanisms contribute to textural changes (Bremner 1992; Mackie 1993; Barroso and others 1998); myofibrillar proteins and collagens aggregate and muscle toughening was observed (Montero and Borderías 1990a, 1992). 
Prolonged frozen storage induces loss of water-holding capacity and increased protein-protein interaction (Dyer and Dingle 1961; Connell 1964). Ice crystals, formed during frozen storage, damage muscle structure and cause protein denaturation in frozen fish (Sikorski and others 1976). Protein denaturation is not the only cause of increased firmness. Howgate (1977) found that the sarcoplasmic reticulum degrades and acts like cement to hold the individual myofibrils together.

\section{EFFECT OF COOKING}

Heat during conventional cooking destroys enzymatic activities of myosin and actomyosin and causes denaturation of myosin (Foegeding and Lanier 1996). Stability of myosin and actomyosin depends on the habitat water temperature of fish (Tsuchimoto and others 1988); however, collagen is not affected (Lavety and others 1988). Water loss during cooking is due to changes in the connective tissue accompanied by transverse shrinkage of the muscle cells, intercellular gaps, and widening of the extra-cellular spaces (Ofstad and others 1993). Heatinduced denaturation of muscle protein and decreased water-holding capacity account for an increase in texture. In rainbow trout, denaturation of muscle fibers and water loss due to heating causes a substantial increase in cooked fillet firmness (Schubring 2008). Thermal denaturation and stability of fish myosins has been described by several techniques such as differential scanning calorimetry (Chan and others 1992).

\section{COLLAGEN CONTRIBUTION TO FILLET TEXTURE}

Collagen is the major connective tissue protein constituting $3-10 \%$ of the proteins in fish muscle; it plays a key role in maintaining the integrity of the fillet (Sikorski and others 1984). Fish muscle contains up to 10 times less collagen than red meats (Love 1988). Collagen fibers arise 
from myosepts to form a connective tissue envelope around each muscle fiber; this envelope is called the perimysium. Muscle fibers fit into socket-like invaginations of the myocommata made of collagen (Bremner and Hallett 1985). Sheets of connective tissue also run between bundles of muscle fibers and are particularly numerous towards the tail. The amount of collagen changes little during muscle growth (Goll and others 1963). The amount of insoluble collagen of cod increases only slightly with age; starving fish produce more collagen and collagen with a greater degree of cross-linking than do fish that are well fed (Love 1980). Older fish, with much thicker myocommata, have more collagen with fewer cross-links than younger fish (Hultin 1985; Montero and Borderias 1990). Farmed Atlantic halibut mobilizes fast muscle protein to build up gonads with a less significant effect on insoluble collagen compared with the soluble fraction $(P<0.01 \mathrm{v}$. $P<0.001$; Haugen 2006). Muscle connective tissue in the trout (1800g) was more abundant and collagen exhibited a lower level of cross-links (Montero and Borderias 1990b). The divalent hydroxylysyl pyridinoline (PYD) is a mature cross-link that accumulates in muscle tissue with age and found to increase fillet firmness (Haugen and others 2006). Amount of characteristic amino acid hydroxyproline (HYP) has been used to determine collagen content in muscle (McCormick 1999), and concentration of mature, heat-stable cross-link is positively related to degree of HYP insolubility. Almost $100 \%$ of PYD cross-links were recovered in the a-i fraction ( $\mathrm{Li}$ and others 2005). The insoluble fraction of HYP positively correlated with energy of shear in salmon (Li and others 2005) and red sea bream (Hagen and others 2007). Like other mature cross-links, the role of PYD in muscle involves maintaining physical structure and rigidity of the collegen matrix (Bailey 1998). The PYD cross-links concentration contributed to $25 \%$ of the variation in fillet firmness in the Atlantic salmon ( $\mathrm{Li}$ and others 2005) and 64\% in Atlantic halibut (Hagen and others 2007). 
During fish growth, distribution of molecular species of collagen change, overall amount of collagen, and its degree of crosslinking change. Distinct types of collagen in various tissues exhibit differences in 1) the number of $\alpha 1$ and $\alpha 2$ chains in the molecules, 2) the content of hydroxyproline and hydroxylysine residues, 3) the amount, characteristics, and mode of attachment of carbohydrates, and 4) the ability of forming fibers (Sikorski and others 1984). In teleost fish muscle, there are two main types of collagen, type I and V collagens, with different biochemical characteristics. Post-mortem proteolysis by collagenases is associated with the breakdown of type IV and I collagen, and these changes resulted in an increase in collagen solubility and softening of fillets (Foegeding and others 1996). Matrix metalloproteases, responsible for connective tissue breakdown, have been reported in rockfish (Bracho and Haard 1995), salmon (Stoknes and Rustad 1995), cod (Lodemel and others 2004), and rainbow trout muscle (Saito and others 2000a, b).

\section{INSTRUMENTAL TEXTURE MEASUREMENT}

Food texture is a sensory parameter covering several related physical properties (Einen and Thomassen 2002). To determine food texture sensorially, however, requires a highly trained panel and can be time consuming. On the other hands, instrumental testing is relatively inexpensive and more repeatable than sensory testing. It has been used to evaluate food texture, and the result is related to sensory test results. Lack of correlation between instrumental and sensory methods is observed due to differences in sensitivity; sensory testing can respond to multiple attributes while instrumental tests evaluate a single dimension of the overall texture experience (Muñtoz and others 1986). In addition, instrumental testing is usually performed on raw fish; whereas, sensory testing 
is performed on cooked fish in which muscle structure is altered by the cooking process. Identifying instrumental parameters that are highly correlated with critical sensory variables would help to elucidate ante- and post-mortem factors that influence fillet texture and predict consumer responses (Morkore and Einen 2002).

Instrumental texture devices can be categorized according to 1) how force is applied, 2) the type of action, 3) the way meat is prepared and oriented within the device, and 4) the way measurements are expressed (Purchas 2004). Because the majority of textural parameters of foods are sensed in the mouth and mastication is a destructive process, Bourne (1982) suggested that destructive tests should be the predominant type used for foods. However, Sigurgisladottir and others (1999) indicated that shear force gives the most sensitive measurement, but its destruction of fish muscle is the drawback. The deformation mechanism can be characterized based on the direction of stress application, into shearing, compressive, and tensile action (Matuszek 2002). Texture measurements using shearing, compressive, and tensile mechanisms correlated with sensory assessments (Torrissen and others 2001). Different methods yield a variety of parameters that differ with respect to their repeatability of the measurement, sensitivity in detecting texture difference, and correlation of the measurement to those of sensory assessment. The drawback of using traditional methods designed for terrestrial food animals is due to the different musculature of fish; a different deformation mechanism causes misinterpretation of texture analysis. In addition, in cooked fish, the muscle segments tend to slide upon compression making it impossible to reproduce the results (Borderias and others 1983). Well-defined conditions for a test on whole muscle that yield several parameters on the force-deformation curves may give accurate information on the mechanical properties of the connective tissue and the myofibers (Voisey 1976). The increase in firmness from head to tail reflects the increase in connective tissue and 
muscle fiber density (Kiessling and others 2006). Jonsson and others (2001) found that the Warner-Bratzler shear cell could separate textural properties in different muscle segments of raw salmon fillets. Amplitude of shear force and ability to separate texture difference from head to tail, determined by shearing method using a knife blade, were superior to hardness that was measured by the puncture method using a flat-ended cylinder and sphere (Sigurgisladottir and others 1999). Shearing method using the Warner-Bratzler device could differentiate textural properties of different parts of raw salmon fillets (Jonsson and others 2001) and detect texture difference between raw and smoked salmon (Einen and Thomassen 2002). Sigurgisladottir and others (1999) found the shearing method, based on cutting with a knife blade, was more sensitive than the puncture method and could discriminate textural properties in different fillet locations. However, Mørkøre and Einen (2003) showed that firmness, determined by compression test with a cylindrical probe, was superior to a shear test with Allo-Kramer shear cell in correlating instrumental and sensory firmness (Mørkøre and Einen 2003). Veland and Torrissen (1999) indicated that the shear test applies only one deformation to the sample and thus gives no measure of how much of the applied work is absorbed as elastic deformation, or of the work required in successive chewing.

Biological and processing factors affect muscle composition and structure, and therefore, fillet texture. Reliability of instrumental method depends on if and how well the relationship between the measurement and key determinants to differences in texture is established. In characterizing textural attributes of fish fillets, the basic understanding is that heterogeneity of fish fillets and deformation mechanism determine a choice of method and texture parameter, and correct interpretation. 


\section{REFERENCES}

Ando M, Toyohara H, Sakaguchi M. 1992a. Post-mortem tenderization of rainbow trout muscle caused by the disintegration of collagen fibres in the pericellular connective tissue. Nippon Suisan Gakkaishi 58: 567-570.

Ando M, Toyohara H, Sakaguchi M. 1992b. Three-dimensional structure of collagen fibrillar network of pericellular connective tissue in association with firmness of fish muscle. Nippon Suisan Gakkaishi 58: 1361-1364.

Barroso M, Careche M, Borderias AJ. (1998). Quality control of frozen fish using rheological techniques. Trends in Food Science and Technology 9: 223-229.

Birkeland S, Bencze Røra AM, Skara T, Bjerkeng B. 2004. Effects of cold smoking procedures and raw material characteristics on product yield and quality parameters of cold smoked Atlantic salmon (Salmo salar L.) fillets. Food Res Int 37: 273-86.

Borderias AJ, Lamua M, Tejada M. 1983. Texture analysis of fish fillets and minced fish by both sensory and instrumental methods. J Food Sci 18: 85-95.

Botta JR. 1991. Instrumental for nondestructive texture measurement of raw Atlantic cod (Gadus morhua) fillets. J Food Sci 56: 962-968.

Bourne MC. 1982. Selection of a suitable test procedure. In: Bourne MC, editor. Food texture and viscosity: concept and measurement. New York: Academic Press. p 280-293.

Bourne M. 2002. Food texture and viscosity: concept and measurement. $2^{\text {nd }}$ ed. New York: Academic Press. 427 p.

Bracho G, Haard N. 1995. Identification of two matrix metalloproteinases in the skeletal muscle of pacific rockfish (Sebastes sp.). J Food Biochem. 19: 299-319.

Bremner HA, Hallet IC. 1985. Muscle fibre - connective tissue junctions in the blue grenadier (Macruronus novaezelandiae). J Food Sci. 50: 975-980.

Bremner HA. 1992. Fish flesh structure and the role of collagen-Its post mortem aspects and implication for fish processing. In: Huss $\mathrm{HH}$, editor. Quality assurance in the fish industry. Amsterdam: Elsevier. p 39-62.

Bugeon J, Lefevre F, Mireille C, Uyanik A, Davenel A, Haffray P. 2010. Flesh quality in large rainbow trout with high or low fillet yield. J Muscle Foods 21: 702-721.

Busconi L, Folco EJ, Martone CB, Sanchez JJ. 1989. Post-mortem changes in cytoskeletal elements of fish muscle. J Food Biochem 13: 443-451. 
Chan JK, Gill TA, Paulson AT. 1992. The dynamics of thermal denaturation of fish myosins. Food Res Int 25: 117-123.

Connell J. 1964. Fish muscle proteins and some effects on them of processing. In: Schultz HW, Anglemier AF, editors. Proteins and their reactions. Westport, Conn.: Avi.

Dyer WJ, Dingle JR. 1961. Fish proteins with special reference to freezing. In: Borgstrom G, editor. Fish as food. New York: Academic Press. p 275.

Einen O, Thomassen MS. 2002. Relating sensory and instrumental texture analyses of Atlantic salmon. J Food Sci 68(4): 1492-1497.

Færgemand J, Ronsholdt B, Alsted N, Borresen T. 1995. Fillet texture of rainbow trout as as affected by feeding strategy, slaughtering procedure and storage post mortem. Wat Sci Technol 31: 225-231.

Foegeding EA, Lanier TC. 1996. Characteristics of edible muscle tissues. In: Fennema OR, editor. Food chemistry. New York: Marcel Dekker, Inc. p 879-942.

Goll DE, Bray RW, Hoekstra WG. 1963. Age-associated changes in muscle composition. The isolation and properties of a collagenous residue from bovine muscle. J Food Sci 28: 503509.

Guinard J-X, Mazzucchelli R. 1996. The sensory perception of texture and mouth-feel. Trends Food Sci Technol. 7: 213-219.

Haugen T, Kiessling A, Olsen RE, Rora MB, Slinde E, Nortvedt R. 2006. Seasonal variation in muscle growth dynamics and selected quality attributes in Atlantic halibut (Hippoglossus hippoglossus L.) fed dietary lipids containing soybean and/or herring oil under different rearing regimes. Aquaculture 261: 565-579.

Hagen O, Solberg C, Sirnes E, Johnston IA. 2007. Biochemical and structural factors contributing to seasonal variation in the texture of farmed Atlantic halibut (Hippoglossus hippoglossus L.) flesh. J Agric Food Chem. 55: 5803-5808.

Hagen O, Solberg C, Johnston IA. 2008. Activity of aspargate (cathepsin D), cysteine protease (cathepsin B, B + L and H), and matrix metallopeptidase (collagen) and their influence on protein and water-holding capacity of muscle in commercially farmed Atlantic halibut (Hippoglossus hippoglossus L.). J Agric Food Chem 56: 5953-5959.

Hatae K, Tobimatsu A, Takeyama M, Matsumoto JJ. 1986. Contribution of the connective tissue on the textural difference of various fish species. Bull Jap Soc Fish 52: 2001-2008.

Hultin HO. 1985. Characteristics of muscle tissue. In: Fennema OR, editor. Food chemistry. New York: Marcel Dekker. p 725-789. 
Hurling R, Rodell JB, Hunter HD. 1996. Research note: Fibre diameter and fish texture. J Texture Studies 27: 679-685.

Hyldig G, Nielsen D. 2007. Texture of fish, fish products, and shellfish. In: Nollet LML, editor. Handbook of meat, poultry and seafood quality. Ames, IA: Blackwell Publishing. p 549561.

Johnston I A, Xuejum Li, Vieira VLA, Nickell D, Dingwall A., Alderson R, Campbell P, Bickerdike, R. 2006. Muscle and flesh quality traits in wild and farmed Atlantic salmon. Aquaculture 256: 323-336.

Jonsson A, Sigurgisladottir H, Hafteinsson H, Kristbergsson K. 2001. Textural properties of raw Atlantic salmon (Salmo salar) fillets measured by different methods in comparison to expressible moisture. Aquaculture Nutrition 7: 81-89.

Jowitt R. 1974. The terminology of food texture. J Texture Studies 5: 351-358.

Kiessling A, Ruohonen K, Bjornevik M. 2006. Muscle fibre growth and quality in fish. Arch Tierz., Dummerstorf 49: 137-146.

Koteng DF. 1992. Markedsundersøgelse—-Norsk Laks. Fiskerinæringens Landsforening, Norway . Howgate P. 1977. Aspects of fish texture. In: Birch GC, Brennan JG, Parker KJ, editors. Sensory properties of foods. London: Applied Science Publishers Ltd. p 249-269.

Lavety J, Afolabi OA, Love RM. 1988. The connective tissues of fish. IX. Gaping in farmed species. Int J Food Sci Technol. 23: 23-30.

Li X, Bickerdike R, Lindsay E, Campbell P, Nickell D, Dingwall A, Johnston IA. 2005. Hydroxylysyl pyridinoline cross-link concentration affects the textural properties of fresh and smoked Atlantic salmon (Salmo salar L.) flesh. J Agric Food Chem 53: 6844-6850.

Lodemel J, Maehre H, Winberg J, Olsen R. 2004. Tissue distribution, inhibition and activation of gelatinolytic activities in Atlantic cod (Gadus morhua). Comp Biochem Physiol 137B: 363-371.

Love RM. 1988. The food fishes: their intrinsic variation and practical implications. London: Farrand Press.

Mackie IM. 1993. The effects of freezing on flesh proteins. Food Rev Int. 9: 575-610.

Martin SA, Blaney S, Bowman AS, Houlihan DF. 2002. Ubiquitin-proteasome-dependent proteolysis in rainbow trout (Oncorhynchus mykiss): effect of food deprivation. Pflugers Arch 445(2): 257-66.

Matuszek T. 2002. Rheological properties of food systems. In: Sikorski ZE, editor. Chemical and functional properties of food components. FL: CRC Press LLC. p 179-204. 
McCormick RJ. 1999. Extracellular modification to muscle collagen: implications for meat quality. Poultry Science 78: 785-791.

Meilgaard MC, Civille GV, Carr BT. 2006. Sensory evaluation techniques. $4^{\text {th }}$ ed. NY: CRC Press LLC.

Montero P, Borderías J. 1990a. Behaviour of myofibrillar proteins and collagen in hake (Merlucciusmeluccius L.) muscle during frozen storage and its effects on texture. Z. Lebensm. Unters Forsch 190: 112-117.

Montero, P., Borderías, J. 1990b. Effect of rigor mortis and ageing on collagen in trout (Salmo irideus) muscle. J. Sci. Food Agric. 52: 141-146.

Montero P, Borderías J. 1992. Influence of myofibrillar proteins and collagen aggregation on the texture of frozen hake muscle. In: Huss HH, Jakobsen M, Liston J, editors. Quality assurance in the fish industry. Amsterdam: Elsevier Science Publisher BV. p 149-167.

Mørkøre T, Hansen AA, Unander E, Einen O. 2002. Composition, liquid leakage, and mechanical properties of farmed rainbow trout: variation between fillet sections and the impact of ice and frozen storage. J Food Sci 67(5): 1933-1938.

Mørkøre T, Einen O. 2003. Relating sensory and instrumental texture analysis of Atlantic salmon. J Food Sci 68(4): 1492-1497.

Muñtoz AM, Pangborn M, Noble AC. 1986. Sensory and mechanical attributes of gel texture Gelatin, sodium alginate and kappa-carrageenan gels. Journal of Texture Studies 17(1): 1736.

Ofstad R, Kidman S, Myklebust R, Hermansson AM. 1993. Liquid holding capacity and structural changes during heating of fish muscle: Cod (Gadus morhua L.) and salmon (Salmo salar). Food Structure 12: 163-174.

Ofstad R, Olsen RL, Taylor R, Hannesson KO. 2006. Breakdown of intramuscular connective tissue in cod (Gadus morhua L.) and spotted wolfish (Anarhichas minor O.) related to gaping. LWT - Food Science and Technology 39(10): 1143-1154.

Periago MJ, Ayala MD, Lopez-Albors O, Abdel I, Martinez C, Garcia-Alcázar A, Ros G, Gil F. 2005. Muscle cellularity and flesh quality of wild and farmed sea bass, Dicentrarchus labrax L. Aquaculture 249: 175-188.

Piferrer F, Beaumont A, Falguière J-C, Flajšhans M, Haffray P, Colombo L. 2009. Polyploid fish and shellfish: production, biology and applications to aquaculture for performance improvement and genetic containment. Aquaculture 293: 125-156.

Purchas RW. 2004. Tenderness Measurement. In: Jensen WK, editor. Encyclopedia of meat sciences. Elsevier Ltd. p 1370-1376. 
Rasmussen RS. 2001. Quality of farmed salmonids with emphasis on proximate composition, yield and sensory characteristics. Aquac Res 32: 767-786.

Reid RA, Durance TD. 1992. Textural changes of canned of chum salmon related to sexual maturity. J Food Sci 57: 1340-1342.

Roth B, Slinde E, Arildsen J. 2006. Pre or post mortem muscle activity in Atlantic salmon (Salmo salar). The effect on rigor mortis and the physical properties of flesh. Aquaculture 257: 504-510.

Roberts SJ, Lowery MS, Somero GN. 1988. Regulation of binding of phosphofructokinase to myofibrils in the red and white muscle of the barred sand bass, Paralabrax nebulifer (Serranidae). J Exp Biol 137: 13-27.

Saito M, Sato K, Kunisaki N, Kimura S. 2000a. Characterization of a rainbow trout matrix metalloproteinase capable of degrading type I collagen. Eur J Biochem 267(23): 69436950.

Saito M, Kunisaki N, Urano N, Kimura S. 2000b. Characterization of cDNA clone endcoding the matrix metalloproteinase 2 from rainbow trout fibroblast. Fisheries Science 66: 334-342.

Salem M, Kenney PB, Rexroad CE, Yao J. 2006. Molecular characterization of muscle atrophy and proteolysis associated with spawning in rainbow trout. Comp Biochem Physiol D: 227237.

Salem M, Kenney PB, Rexroad 3rd CE, Yao J. 2010. Proteomic signature of muscle atrophy in rainbow trout. Journal of proteomics 73: 778-789.

Sato K, Ohashi C, Ohtsuki K, Kawabata M. 1991. Type V collagen in trout (Salmo gairdneri) muscle and its solubility change during chilled storage of muscle. J Agric Food Chem 39(7): 1222-1225.

Schubring R. 2008. Comparative study of the DSC pattern, color, texture and water-binding capacity of rainbow trout muscle during heating. Journal of Food Processing and Preservation 32: 190-218.

Sigurgisladottir S, Torrissen O, Jonsson A, Lie O, Thomassen MS, Hafsteinsson H. 1997. Salmon quality: methods to determine the quality parameters. Reviews in Fisheries Science 5: 223252.

Sigurgisladottir S, Hafsteinsson A, Jonsson A, Lie A, Nortvedt R, Thomassen M, Torrissen O. 1999. Textural properties of raw salmon fillets as affected by sampling method. J Food Sci 64: 99-104.

Sikorski Z, Olleyb J, Kostuchc S, Olcottd HS. 1976. Protein changes in frozen fish. CRC Crit Rev Food Sci Nutr 8(1): 97-129. 
Sikorski ZE, Scott DN, Buisson DH, Love RM. 1984. The role of collagen in the quality and processing of fish. CRC Crit Rev Food Sci Nutr 20(4): 301-343.

Stoknes I, Rustad T. 1995. Proteolytic activity in muscle from Atlantic salmon (Salmo salar). J Food Sci 60(4): 711-714.

Szczesniak AS. 1963. Classification of textural characteristics. J Food Sci 28: 385-389.

Taylor RG, Fjæra SO, Skjervold PO. 2002. Salmon fillet texture is determined by myofibermyofiber and myofiber-myocommata attachment. J Food Sci 67(6): 2067-2071.

Torrissen OJ, Sigurgisladottir S, Slinde E. 2001. Texture and technological properties of fish. In: Kestin SC, Warriss PD, editors. Farmed fish quality. UK: Blackwell Science. p 42-57.

Toyohara H, Ito K, Ando M, Kinoshita M, Shinizu Y, Sakaguchi M. 1991. Effect of maturation on acitivity of various proteases and protease inhibitors in the muscle of Ayu (Plecoglossus altivelis). Comp Biochem Physiol B99: 419-424.

Tsuchimoto M, Tanaka N, Misima T, Yada S, Senta T, Yasuda M. 1988. The influence of habitat water temperature on the relative thermal stability of myofibrillar $\mathrm{CA}^{2+}$-ATPase in fishes collected in the waters from tropical to frigid zones. Nippon Suisan Gakkaishi 54: 787-793.

van Bohemen CG, Lambert JG, Peute J. 1981. Annual changes in plasma and liver in relation to vitellogenesis in the female rainbow trout, Salmo gairdneri. Gen Comp Endocrinol 44(1): 94-107.

Veland JO, Torrissen OJ. 1999. The texture of Atlantic salmon (Salmosalar) muscle as measured instrumentally using TPA and Warner-Bratzler shear test. J Sci Food Agric 79: 1737-1746.

Verrez-Bagnis V. 1997. Post mortem denaturation of fish muscle proteins -- changes in some myofibrillar, intermediate filament and costameric proteins. In: Olafsdóttir G, Luten J, Dalgaard P, Careche M, Verrez-Bagnis V, Martinsdóttir E, Heia K, editors. Methods to determine the freshness of fish in research and industry. Paris: International Institute of Refrigeration. p 229-237.

Voisey PW. 1976. Engineering assessment and critique of instruments used for meat tenderness evaluation. J Texture Studies 7: 11-48.

Wang J. 2010. Molecular characterization of the MuRF gene family: potential role in rainbow trout muscle degradation. [MSc Thesis]. Morgantown, WV: West Virginia Univ. 51 p. 


\section{CHAPTER 1}

Relating Instrumental Texture, Determined by Variable-Blade and AlloKramer Shear Attachments, to Sensory Analysis of Rainbow Trout, Oncorhynchus mykiss, Fillets 


\begin{abstract}
Texture is one of the most important quality attributes of fish fillets, and accurate assessment of variation in this attribute, as affected by storage and handling, is critical in providing consistent quality product. Trout fillets received 4 treatments: 3-day refrigeration (R3), 7-day refrigeration (R7), 3-day refrigeration followed by 30-day frozen storage (R3F30), and 7-day refrigeration followed by 30-day frozen storage (R7F30). Instrumental texture of raw and cooked fillets was determined by three approaches: five-blade Allo-Kramer (AK) and variable-blade attachment (VB) with 12 blades arranged in perpendicular (PER) and parallel (PAR) orientations to muscle fibers. Correlation between instrumental texture and sensory hardness, juiciness, elasticity, fatness, and coarseness was determined. Muscle $\mathrm{pH}$ remained constant at 6.54-6.64. Raw fillets lost $3.66 \%$ of their original weight after 30 -day frozen storage. After cooking, weight loss further increased to $15.97 \%$. Moisture content decreased from 69.11 to $65.02 \%$ while fat content remained constant at $10.41 \%$. VB detected differences in muscle sample strength $(P=0.0019)$ and demonstrated effect of shear direction reported as maximum force ( $\mathrm{g}$ force/g sample). AK detected differences in energy of shear ( $\left.\mathrm{g}^{*} \mathrm{~mm} ; P=0.0001\right)$. Fillets that received F30 treatments were less extensible. Cooking increased muscle strength and toughness. Force determined by VB was correlated with sensory hardness $(r=0.423, P=0.0394)$ and cook loss $(\mathrm{r}=0.412, P=0.0450)$. Variable-blade attachment is accurate, valid, and less destructive in fillet texture analysis.
\end{abstract}

Keywords: Rainbow trout, texture, sensory analysis, instrumental analysis 


\section{INTRODUCTION}

Texture is an important quality attribute of aquatic foods with a delicate muscle structure. Texture defects such as muscle softening and gaping are caused by ante- and post-mortem handling. The mechanism underlying these problems relates to compositional changes and protein denaturation (Ladrat and others 2006). In describing textural quality of fish fillet, the fracture mechanism needs to be carefully characterized. Fish muscle structure is unique in that muscle flakes (myotomes) are held together by the thin membranous myocommata. This structure differs from muscle connective tissue arrangement in terrestrial mammals where muscle fibers form a bundle that is surrounded by the perimysium. Thus, fish muscle structure is vulnerable because it lacks the complex connective tissue hierarchy of terrestrial, food animal species (Dunajski 1979). The ability of fish fillets to endure force is determined by muscle fibers that run parallel to its skeleton, and fillet integrity is determined by the thin connective tissue membrane between muscle flakes (Foegeding and others 1996). Cooking weakens muscle structure by converting a key component of connective tissue, collagen, to gelatin (Sikorski and others 1984; Light 1987). The muscle structure therefore loses its ability to endure force and thus, easily disintegrates.

Instrumental texture analysis used for terrestrial muscle foods lacks repeatability when used with fish fillets (Borderias and others 1983). In shear test using five-blade Allo-Kramer attachment, the myotome layers tend to slide away by the applied force and resistance to the applied force is accounted for by shearing a bulk of muscle fiber collected within the shear cell area (Figure 1). In measuring fish fillet firmness, the key features for the shearing device are blade thickness and its orientation to the muscle fiber (Smith and Fletcher 1998). A thin blade will cut completely through the muscle fiber; therefore, shear force will not include bulk shearing or 
compression (Borderias and others 1983). Relative to blade orientation, shearing perpendicular to the muscle fiber will measure resistance to the applied force associated with myofiber-tomyocommata attachment (Taylor and others 2002). Compared to a single blade, multiple blades will cover a wider range of texture variation within the fillet sample. Since texture is a sensory attribute, perceived by the senses of touch, sight and hearing, sensory assessment is the only direct and accurate method of measuring texture (Brennan 1980). To be of value, instrumental readings need to be validated with sensory analyses (Bourne 2002). Greater predictability of sensory analyses by instrumental measurements translates into greater validity of instrumental measurements. Sensory evaluations have been used to validate and determine correlations with instrumental texture measurements in avian (Cavitt and others 2004; Xiong and others 2006), terrestrial (Dramsfield and others 1984; de Huidobro and others 2005), and aquatic food products (Mørkøre and Einen 2003; Nielsen and others 2005). Once the instrumental measurement is validated, it can be used to elucidate ante- and post-mortem factors that influence fillet texture.

A study on razor blade shear attachment in broiler breast fillets (Cavitt and others 2005) justified the benefit of using the less destructive and small incision (8.9-mm wide) blade in terms of reduced processing time and labor costs. The present study was conducted to validate a novel, variable-blade shear using sensory analysis, and to compare this device with the widely used Allo-Kramer attachment. It was conducted to specifically characterize attachment features and its application in aquatic food. The new attachment has three key features, lending itself to measuring fish fillet texture. First, a thin blade $(0.635-\mathrm{mm}$ thick) allows shearing of muscle fibers without destroying fillet structure compared to Allo-Kramer blades (3.0-mm thick). Second, the twelve, $12.7 \mathrm{~mm} \times 25.4 \mathrm{~mm}$ blades arranged in two rows on the attachment allow an incision width and depth that capture a wide range of texture variation within the fillet sample. Third, 
removable and rotatable blades allow positioning blades at individual angles and provide flexibility in the number of blades used. The purpose of this experiment was to compare the sensitivity of shearing device (AK and VB) and VB blade orientation (PAR vs. PER) in measuring trout muscle texture. Different refrigeration/ frozen storage time combinations and cooking were used to generate a range of fillet textures. Instrumental measurements were compared with sensory measurements to determine the attachment's accuracy in assessing cooked fillet texture. 


\section{MATERIALS AND METHODS}

\section{Sampling and preparation of fish fillet}

Seventy-two fish $(1149 \pm 234 \mathrm{~g})$ were harvested at The Conservation Fund's Freshwater Institute, Sheperdstown, WV. Fish were mechanically stunned and stored on ice for delivery to Morgantown, WV, an approximate 3.5-hour trip. Fish were eviscerated and filleted within 4 hours after harvest. Whole-fish and fillet weights were collected. Subsequently, fillets were placed on Styrofoam trays and overwrapped with polyvinyl chloride (PVC) plastic film, and they were stored according to the assigned storage treatment. Eighteen fish were assigned to each storage treatment. Storage treatments consisted of eighteen fish refrigerated at $2{ }^{\circ} \mathrm{C}$ for three days $(\mathrm{R} 3)$ and eighteen fish refrigerated for seven days (R7). Two additional sets of eighteen fish were vacuum-packaged and frozen at $-25{ }^{\circ} \mathrm{C}$ for thirty days after three days (R3F30) or seven (R7F30) days of refrigerated storage. However, at the end of storage, sensory and texture analyses were randomly assigned to the left or right side of fillets from all storage regimens to ensure independence. It has been reported that no difference existed in composition (Dunajski 1979) and texture (Taylor and others 2002) between left and right fillets. Seventy-two, randomly-assigned, boneless, skinless fillet halves were sent to the School of Human and Consumer Sciences, Ohio University, Athens, OH for sensory evaluation. The remaining 72 halves were used for instrumental texture analysis. Using the lateral line as a reference, the half was cut into cranial and caudal sections of $40 \mathrm{~mm} \times 80 \mathrm{~mm}$ each. Each section consisted of approximately the same amount of dorsal and ventral muscle. Section location (cranial or caudal half) was randomly assigned for either raw or cooked instrumental evaluation. For cooked evaluation, fillet sections were thermally processed in a microprocessor-controlled smoke oven (Model CVU-490; Enviro-Pak, Clackamas, OR, U.S.A.) 
set at $82{ }^{\circ} \mathrm{C}$, and the cooking process was stopped when the internal fillet temperature reached 65.5 ${ }^{\circ} \mathrm{C}$. This cooking temperature was selected according to the United States Department of Agriculture (USDA) recommended minimum internal temperature (Food Safety Education 2010) for fish to achieve a safe temperature without overcooking. The cooking time was approximately 45 minutes. After product reached room temperature weight was determined for raw and cooked sections, and cook loss was calculated.

\section{Processing loss}

Processing loss is the sum of storage and cook losses.

Storage loss. Thirty six frozen fillets (R3F30 and R7F30) were completely thawed at $4 \pm 1$ ${ }^{\circ} \mathrm{C}$, overnight. Thawed and fresh (R3 and R7) samples were removed from vacuum bags, and blotted dry with tissue paper before weighing. Thaw loss was determined as the percentage of weight loss after thawing.

Cook loss. Following cooking to $65.5{ }^{\circ} \mathrm{C}$, fillets were cooled to room temperature and weighed. The difference between cooked and raw weights was determined, and this difference was expressed as a percentage of the raw weight and designated as percent cook loss.

\section{Instrumental texture analysis}

Texture of raw and cooked fillet sections from each storage regimen was evaluated instrumentally. For each attachment, parameters, determined from the plot of force v. distance, included maximum shear force (g/g sample; Figure 2) and area under the curve from $0 \mathrm{~g}$ force up to the maximum value ( $\mathrm{g}^{*} \mathrm{~mm}$; Figure 2). Sample remaining after analyses were pulverized with 
liquid nitrogen in a Waring Blender (Waring, New Hartford, CT, U.S.A.) and held at $-25{ }^{\circ} \mathrm{C}$ for analysis of $\mathrm{pH}$, and crude fat and moisture content.

Five-blade Allo-Kramer evaluations. The force profile, using a five-blade, Allo-Kramer shear cell, was generated with a Texture Analyzer (Model TA-HDi ${ }^{\circledR}$; Texture Technologies Corp., Scarsdale, NY, U.S.A.), equipped with a 50-kg load cell, at a crosshead speed of $127 \mathrm{~mm} / \mathrm{min}$. The instrument was set 1) to measure force in compression mode and 2) for the attachment to return to start after reaching a specified distance. Pre-test speed was $5 \mathrm{~mm} / \mathrm{sec}$. Test speed was $2 \mathrm{~mm} / \mathrm{sec}$. Post test speed was $10 \mathrm{~mm} / \mathrm{sec}$. The force-distance graphs were recorded and analyzed using the Texture Expert Exceed software (version 2.60; Stable Micro Systems Ltd., Surrey, U.K.).

Variable-blade shear evaluations. A fillet section was placed on a flat base (plastic cutting board). The fillet was adjusted to the blade holder frame $(30 \mathrm{~mm} \times 80 \mathrm{~mm})$ so that the cutting area aligned with the sample surface area. According to muscle fiber direction, blade orientation was changed to provide perpendicular and parallel orientations (Figure 3). Test settings and acquired responses were the same as Allo-Kramer evaluations, except that the attachment was programmed to return to the original distance before the blade touched the base. Depth of penetration was standardized; average $(\mathrm{N}=48)$ blade penetration into raw and cooked fillets was $20.7 \pm 2.7$ and $20.9 \pm 2.5 \mathrm{~mm}$, respectively.

\section{Sensory Texture Analysis}

Fillets were cut into sections and cooked in the same manner as previously described. Fillet sections were served to panelists at room temperature. A sensory panel consisted of six trained members with experience analyzing a variety of meat products (Brannan 2009; Mah and Brannan 2009). Panelists consisted of three men and three women who were employees of Ohio University, 
aged between 18-64 years old. Panelists participated in seventeen, 50-minute general training sessions and four training sessions targeted to cooked fillets prepared from fresh trout prior to sampling. Training and subsequent product testing were based on the Spectrum ${ }^{\mathrm{TM}}$ method (Meilgaard and others 2006). The first of the four training sessions was devoted to re-familiarizing the panel with four attributes with which they had previous experience, namely hardness, elasticity (springiness), juiciness (moisture release), and fatness (oily mouth coating). The second and most of the third sessions were devoted to developing adequate standards for cohesiveness. During the final session, panelists performed a practice on trout fillets using the actual ballot, afterward discussing their calibration. Each panelist evaluated three, randomly selected fillet sections from each storage treatment. Therefore, each panelist evaluated a total of 12 fillet sections (4 storage treatments by 3 replicates), presented monadically. Five sensory attributes were evaluated using a $15-\mathrm{cm}$, unstructured line scale. Hardness was described as the force required to bite through the sample with incisors. Juiciness was the amount of moisture released during a predetermined number of chews. Elasticity was the degree to which the sample returned to its original shape after it was compressed partially with the molars. Fatness was the amount of oily coating that was perceived in the mouth cavity after the sample had been swallowed or expectorated. Coarseness was the feeling of large coarse fibers in the mouth. Anchored references of sensory attributes and their position on 15-cm line scale are shown in Table 1.

\section{Chemical analysis}

pH. Five grams of powdered raw sample were mixed with $25-\mathrm{mL}$ distilled water, and $\mathrm{pH}$ was measured using a flat surface combination electrode (pH/ion analyzer 350; Corning Inc., NY, U.S.A.). Duplicate measurements were averaged and used as the observation for that sample. 
Fat and moisture content. Raw and cooked muscle crude fat and moisture content was determined using AOAC (1990) approved methods. Crude fat was analyzed using the Soxhlet solvent extractor, and moisture was determined according to the oven-drying method $\left(100{ }^{\circ} \mathrm{C}\right.$ for $18 \mathrm{~h})$.

\section{Experimental Design and Statistical Analysis}

The experiment was conducted in the context of a completely randomized design. Analysis of variance (ANOVA) was performed on all data set using the Mixed Model (MIXED) procedure of SAS ${ }^{\circledR}$ system for Window, version 9.1 (SAS Institute Inc 2004). Storage regimen was treated as a fixed main effect for processing loss, muscle $\mathrm{pH}$, and sensory data. Effect of storage regimen, cooking state, and their interaction on composition and instrumental texture data were determined. For sensory data, panelist and panelist*storage regimen interaction (if significant) were treated as random effects. Using MIXED procedure, variance components were estimated by the restricted maximum likelihood method (Littel and others 2006) for testing the significance of fixed effects. An adjustment to standard errors and test statistics and the degree of freedom approximation were performed by the Kenward-Roger correction (Kenward and Roger 1997). Principal component analysis of sensory data was performed by the FACTOR procedure of $\mathrm{SAS}^{\circledR}$ system for Window, version 9.1 (SAS Institute Inc 2004). Varimax rotation was used to align the direction of maximum variation with the first principal axis (McGarigal and others 2000). On each principal component, coefficient (loading) of 0.6 was used as a criterion for selecting important original variables which were five sensory attributes (Hair and others 2005). A plot of the loadings between the first two components was constructed by $\mathrm{JMP}^{\circledR}$, version 7.0 (SAS Institute Inc 2005). The Pearson productmoment correlation analysis between instrumental, processing loss, and sensory attributes was 
performed by CORR procedure of SAS ${ }^{\circledR}$ system for Window, version 9.1 (SAS Institute Inc 2004). Significance was defined at $P<0.05$. 


\section{RESULTS AND DISCUSSION}

\section{Processing loss, muscle $\mathrm{pH}$, and composition}

Storage regimen and cooking state were used to create variation in fillet texture. Regardless of length of refrigerated storage, storage loss increased following a 30-day frozen storage period $(P<0.0001)$ (Figure 4). Refrigerated storage (R3 and R7) caused an average weight loss of $0.96 \%$ in raw fillets. Storage losses increased to $3.66 \%$ after the fillets were frozen for thirty days (R3F30 and R7F30). Storage regimen did not affect $(P>0.05)$ weight loss in cooked fillets. A total cooked loss of $15.97 \%$ was observed for all storage regimens. Storage regimen did not affect $\mathrm{pH}$ ( $P=0.0861$; Table 2); muscle $\mathrm{pH}$ ranged from 6.54 to 6.64 for the storage protocols studied. In farmed halibut muscle, liquid loss increased at a $\mathrm{pH}$ lower than 6.3; whereas, at a higher $\mathrm{pH}$, the loss was independent of $\mathrm{pH}$ (Olsson and others 2003). However, $\mathrm{pH}$ alone does not explain the differences in water-holding capacity of fish muscle. A low $\mathrm{pH}$ in combination with pronounced structural degradation influences water-holding capacity more than low $\mathrm{pH}$ in combination with minor structural degradation (Olsson and others 2003). In the current study, it is likely that the structural breakdown caused by freezing was responsible for differences between fresh and cooked fillets.

Cooking decreased fillet moisture content $(P<0.0001$; Table 2$)$. Cooking state and storage regimen did not affect $(P=0.4438)$ fillet fat content. In view of a decrease in moisture content, a constant fillet fat content suggests that fat loss occurred during cooking but not to the extent that fillet fat content was affected. However, increasing fat content and decreasing cooking loss was observed for salmon fillets, and this negative relationship was more pronounced for the frozen, stored sample (Mørkøre and others 2001). Mørkøre and others (2001) suggested that muscle fat 
behaves like a physical barrier to the release of fluid, and denaturation of muscle protein by freezing reduces its water-binding capacity. Furthermore, it was found that the physical barrier to fluid release could be altered by collagen melting at $20{ }^{\circ} \mathrm{C}$ (Ofstad and others 1993). Fish muscle quality is profoundly affected by water content and water's distribution within the flesh. Ofstad and others (1996) found that the higher water-holding capacity of the salmon muscle was related to species specific structural features and better stability of the muscle proteins. Water-holding capacity is affected by post-mortem proteolytic degradation of myofibrillar structures and connective tissue networks (Ashie and Simpson 1997, 1998). Detachment of sarcolemma, gaps in the extracellular matrix, increased intermyofibrillar space, and transverse shrinkage of cells decreased water-holding capacity (Olsson and others 2003).

\section{Instrumental Texture Analysis}

According to Dobraszczyk and Vincent (1999), strength and toughness are different mechanical properties that can be expressed by different parameters. Maximum force, which is defined as the maximum stress an object will withstand before it breaks, only reflects strength of muscle. On the other hand, area which is defined as the energy required to propagate a fracture by a given crack area reflects toughness or extensibility of muscle (Dobraszczyk and Vincent 1999). VB could detect differences in strength of muscle sample as determined by maximum force (regimen* cooking state effect; $P=0.0019$; Figure 5). Raw muscle tended to be weaker after 30-day frozen storage (F30). The fillets received R3 and R7 treatment yielded $126.59 \mathrm{~g} / \mathrm{g}$ while those received R3F30 and R7F30 yielded $85.41 \mathrm{~g} / \mathrm{g}$. Strength of muscle increased after cooking $(P<0.0001)$ and the effect of storage regimen on texture reversed in cooked fillets. Cooked fillets received R3F30 and R7F30 treatments were stronger than those of R3 and R7 (304.33 g/g v. $238.47 \mathrm{~g} / \mathrm{g} ; P>0.05)$. In broiler breasts, tenderness determined by Meullenet-Owens razor shear 
force and energy decreased during long-term frozen storage (4 months) due to moisture reduction that caused muscle shrinkage (Lee and others 2008). Lee and others (2008) indicated that loss of water-holding capacity and failure of the fibers to reabsorb moisture during meat processing are phenomena commonly observed in frozen and thawed meat. Increased damage of myofibrillar and sarcoplasmic proteins occurs as time and temperature of frozen storage increases (Xiong 1997). In the present study, a 3.66\% weight loss in raw fillets stored frozen for 30 days (F30) coincided with a decrease in raw shear force by $32.52 \%$ and the F30 treatment tended to increase force value in cooked fillets (Figure 5). These observations suggest that frozen storage weakened fillet structural components that, consequently, caused a loss in fillet integrity. In cooked fillets, water loss due to evaporation and drip, and cooking appear to contribute to increased force value. A substantial increase in cooked fillet firmness was due to denaturation of muscle fibers and water loss (Schubring 2008). Heat-induced increased muscle protein-protein interactions and decreases in water-holding capacity occur in two phases (Hamm 1977). Between $30-50{ }^{\circ} \mathrm{C}$, coagulation of myofibrillar proteins takes place, and the largest decrease in water-binding capacity is observed. From 55 to $90{ }^{\circ} \mathrm{C}$, shrinkage of muscle fibers in the connective tissue network and increased interaction of the coagulated actomyosin system cause smaller amounts of water to escape.

In the present study, area under a force-deformation curve $(\mathrm{g} * \mathrm{~mm})$ was determined. The area data was recorded starting when the blade touched sample (force $=0 \mathrm{~g}$ ) until the maximum force was achieved. Since the area after the maximum force was generated after a bundle of muscle fibers broke and the attachment traveled back to the origin, this portion of energy could be largely attributed to the friction between the blade and the sample. We speculated that it is highly variable between $\mathrm{AK}$ and $\mathrm{VB}$ based on different distance on their way back to the origin; therefore, the area after maximum force was excluded. AK could detect the effect of storage 
regimen*cooking state on fillet toughness expressed by energy of shear ( $\mathrm{P}=0.0001$; Figure 6). F30 treatment decreased extensibility of raw muscle $(P<0.05)$. Regardless of refrigerated storage treatment, average energy of shear decreased by 1.87 times after $30 \mathrm{~d}$ of frozen storage (F30; from $106,779$ to $57,060 \mathrm{~g} * \mathrm{~mm})$. Increased energy of shear for cooked fillets suggested that they were more extensible than their raw state $(P<0.0001)$. Energy of shear for cooked fillets ranged from 139,789 to $162,557 \mathrm{~g} * \mathrm{~mm}$ and could not be differentiated by F30 treatment. VB could detect effect of cooking state on energy of shear $(P<0.0001)$. Cooked fillets were tougher than raw fillets (91,001 v. $34,754 \mathrm{~g}^{*} \mathrm{~mm}$ ). According to Dobraszczyk and Vincent (1999), energy analysis is limited by the assumption that deformation of food materials follows linear elastic brittle behavior; rather, they deform by plastic flow or ductile behavior. Therefore, it should be noted that the total area under the force-extension curve will contain the combined contributions from other energy losses which include yield and plastic flow, buckling, and debonding and delamination around fibers and particles within the food (Dobraszczyk and Vincent 1999).

Regarding blade orientation of the variable-blade attachment, higher force was obtained when the blade sheared through muscle fiber perpendicularly. VBPAR could detect differences between raw and cooked fillets (67.98 v. $157.81 \mathrm{~g} / \mathrm{g}$ force; $P<0.0001)$. Averaged across all storage treatment groups, VB yielded 1.56 (raw fillets) and 1.72 (cooked fillets) times higher force $(\mathrm{g} / \mathrm{g}$ ) than VBPAR. According to Bourne (2002), meat is the anisotropic material displaying different properties and/or different values of properties when measured along axes in different directions. Therefore, it is necessary to always set the blade to cut in a certain direction to ensure consistent results. Altering shear angle to a direction other than perpendicular to the muscle fiber $\left(90^{\circ}\right)$ lowered $(P<0.05)$ Allo-Kramer shear values of broiler breast meat (Smith and Fletcher 1998). Using a five-blade Allo-Kramer shear attachment, perpendicularly oriented salmon muscle had a 
2-fold higher shear force, and tests were more repeatable. This attachment was more capable of detecting texture changes throughout 14 days storage on ice when muscle was in a perpendicular orientation (Bourne 2002). In terrestrial food animal species, shearing muscle perpendicular to the fibers involves cutting fibers and connective tissue; whereas, shear force parallel to the fibers involves mostly connective tissue breakage (Swatland 1978). In fish, perpendicular and parallel shear directions will affect connective tissue mainly at the myocommata where deformation of a fillet begins. To describe the effect of shear direction on fillet texture measurement, the current study raises concern about shearing blade thickness. Blade thickness is a critical issue for fish because of its unique muscle structure. Xiong and others (2006) demonstrated that a single razor blade yielded similar results as the 10-blade Allo-Kramer and the Warner-Bratzler shear attachments in measuring broiler meat tenderness. This single-blade data also best predicted descriptive sensory tenderness (hardness). In the current study, the variable-blade attachment, consisting of twelve, $0.635-\mathrm{mm}$ thick, $12.7-\mathrm{mm}$ wide, shear blades was able to shear through the fillet with little disturbance to the rest of the fillet. For the cooked fillet, the blades were able to pass through the surface skin (pellicle) and muscle bundle (Figure 3c). The myotomes did not slip past each other as force of compression was applied; therefore, enabling characterization of muscle fiber and connective tissue contribution to a resistance to the applied force. Moreover, since it is less destructive, the variable-blade attachment tends to improve the precision of a measurement. In contrast, the Allo-Kramer shear attachment, consisting of five $3.0-\mathrm{mm}$ thick and $70-\mathrm{mm}$ wide blades, destroyed the fillet structure, and the myotomes began to slip past each other as force was applied (Figure $1 \mathrm{~b}$ and 1c). The two types of attachment used in the present study seemed to fit different 'shear' actions described by Bourne (2002). Allo-Kramer demonstrated 'true shear failure' in which there is the sliding of the contiguous parts of a body relative to each other in a 
direction parallel to the plane of contact under the influence of a force tangential to the section on which it acts. The variable blade tended to demonstrate 'cutting-shear failure' in which cutting action causes the product to be divided into two pieces. The present study demonstrated the capability of VB and AK to differentiate fillet texture variation created by cold storage and cooking state. Future research needs are 1) to investigate variation in fillet texture and determine whether fillet thickness and myotome orientation affects shear action, and 2) to define the key contributors to resistance to the applied force. Subsequently, the terminology that describes shear action in fish fillets will be defined.

\section{Sensory Analysis}

Mixed model analysis showed that storage regimen had no effect $(P>0.05)$ on sensory attributes with exception for elasticity ( $P=0.0009$; Table 3 ). Degree of elasticity of cooked fillets, though not clearly separated, tended to increase by the increasing storage time. Refrigerated fillets (R3 and R7) had the lower elasticity score (average of 3.06) than frozen fillets (R3F30 and R7F30; average of 4.25). The effect of storage regimen by panelist interaction was significant for juiciness ( $P=0.0080)$, fatness $(P=0.0230)$, and coarseness $(P<0.0001)$ attributes. The panelist effect were also significant for hardness $(P=0.0392)$ and elasticity $(P<0.0001)$ attributes, which means that different panelists used slightly different parts of the scales (Lawless and Heymann 1999). Significant panelist effect is a common finding even when using a panel that is supposedly highly calibrated according to Lawless and Heymann (1999). However, significance of storage regimen*panelist effect could indicate the variation inherent in perception of inhomogeneous samples of this kind, as discussed by Meilgaard and others (2006). The significant interaction effect suggested that, perhaps, sample uniformity was affected by storage regimen, and this effect could contribute to low correlation between instrumental and sensory data. Moreover, presentation 
of a uniform fillet sample, requiring minimal handling by panelists, is critical to reduce unexplained variation in the sensory evaluation of texture because fillet texture is easily modified during handling.

Fish muscle texture depends on a number of intrinsic factors, including fat and moisture content. According to Bourne (2002), "textural properties" have been used to describe a group of physical characteristics that arise from the structural elements of the food which can be sensed primarily by the feeling of touch. These properties are related to the deformation, disintegration, and flow of the food under a force, and are measured objectively by functions of mass, time, and distance. Realized that texture is a multifaceted group of properties of foods, five key sensory attributes were chosen to relate with instrumental texture measurement. In smoked salmon (fillet fat content $=15 \%$ ) fatty texture score was correlated with fat content and visible fat deposits $(\mathrm{r}=0.80, P<0.05)$, but fat content was not correlated with sensory score for firmness, melting or pasty texture (Mørkøre and others 2001). In agreement with Mørkøre and others (2001), the present study found that sensory attributes were not correlated with moisture $(65 \%)$ and fat content $(10-11 \%)$ in cooked fillet $(P>0.05)$. In herring, water-holding capacity of raw fillets positively correlated with sensory firmness, and negatively correlated with fatty mouth feel, juiciness, and grittiness $(P<0.0001 ;$ Nielsen and others 2005). In halibut, liquid loss and fat content were associated with the attributes firmness, fibrousness, and chewiness (Olsson and others 2003). Fillets with a high fat content (3.4-7.3\% wet weight) were described as juicier than fillets with a low fat content (2.9-4.6\% wet weight; Nortvedt and Tuene 1998).

Principal component analysis (PCA) was used to identify the axes along which the maximum variation in sensory data occurs. A useful dimensional reduction of multivariate data sets will often retain $70 \%$ to $80 \%$ of the variation in the first three dimensions (Kilcast 1999). The 
coefficients (loadings) of the original variables (sensory attributes) on the new axes measure the importance of the attributes to total variation in the data set. This analysis showed that the first axis (PC1) captured $44 \%$ of the total variance in the data set and has elasticity, hardness, and fatness as the key components. Juiciness and coarseness were loaded to the second component (PC2) that captured another $22 \%$ of total variance in the data set. Cumulatively, the first three axes captured $82 \%$ of the total variance in the data set. Hardness, elasticity, and fatness were equally important to PC1 with loading ranging from 0.7 to 0.8 . The loading plot (Figure 7) shows relationship between sensory attributes along each axis. Hardness and elasticity were clustered in one group and were inversely related to fatness. This observation agrees with Mørkøre and Einen (2003) who showed that hardness mean score clustered with elasticity mean score in smoked salmon, sensory analysis. Both responses were negatively related to fatness, and they were related to juiciness and coarseness to a lesser degree.

\section{Correlating instrumental to sensory texture}

VB force correlated with hardness $(\mathrm{r}=0.423, P=0.0394$; Table 4), which is an important descriptor for characterizing quality of aquatic food products (Bourne 2002). This sensory attribute was correlated with shear value for rainbow trout fillets (Mørkøre and others 2002) and broiler breast fillets (Xiong and others 2006). In the current study, VB area was also correlated with cook loss $(\mathrm{r}=0.412, P=0.045)$. Correlation between instrumental texture and fillet weight loss was observed in meagre (Argyrosomus regius) fillets stored on ice at $4{ }^{\circ} \mathrm{C}$ (Hernández and others 2009). Hernández and others (2009) found that hardness was correlated with storage time $(\mathrm{r}=-0.68$, $P<0.05)$. Variable-blade attachment, arranged in perpendicular direction, appears to have potential for predicting cooked fillet texture as affected by cold storage. 
The common pattern of muscle fiber rupture at small extensions and subsequent connective tissue rupture in the shear and bite tests has important parallels in the tensile fracture behavior of cooked meat (Purslow 1991). Purslow (1991) described that structural fracture mechanisms of cooked beef muscle (musculus semitendinosus) during tensile tests across the fiber direction involve two separate events which are perimysial-endomysial junction separation and rupture of isolated perimysial strand. The present study showed that muscle fiber orientation affected texture measurements and could be determined by the variable-blade attachment. Warner-Bratzler shear method relates primarily to the strength of the myofibrillar mass, and it was related to sensory evaluation when bitten across fibers (Harris and Shorthose 1988). Rosental (1999) indicated that human testing methodology allows some factors (e.g., temperature, saliva) to influence the test result, and thus the relationships between some sensory characteristics that instrumental measurement purports to measure are not linear. In addition, instrumental shear test can be considered empirical which is usually specific to particularly narrow ranges of products (Bagley and Christianson 1987); therefore, it tends not to compare well and cannot be used for predictions. Muscle fiber orientation is easier to control in instrumental than in sensory evaluations (Tornberg 1996). This caveat may explain the low correlation between instrumental data and hardness score in the current study.

Texture evaluations, assessed by a compression test (10 mm-diameter cylindrical probe) performed on cooked beef, are better predictors of sensory texture than shear tests (WarnerBratzler shear blade) according to de Huidobro and others (2005). In fish, a decrease in firmness was observed, likely due to disintegration of the muscle fiber. When applying a compression force to a cooked fillet, the layered myotomes tend to slide away from the force of compression (Borderias and others 1983). In a Warner-Bratzler shear test, confounding properties that exist 
during sample testing contribute to a wide range of its measurement's correlation with sensory tenderness of terrestrial meat (Szczesniak and Torgeson 1965). During a shearing action, viscoelastic property indicative of firmness was found combine with tensile rupturing property of meat (Stanley 1976). In attempt to correct the drawbacks of a widely used method in mostly done in terrestrial meat, the present study demonstrated that the variable-blade attachment did not destroy fillet structure, and thus allowed measuring resistance of muscle fiber to shear force devoid of bulk compression. A wide variation in correlation coefficients observed could be accounted for by a lack of sample uniformity and greater textural range. Since most texture tests are destructive, a sensory and an instrumental test cannot be performed on the same sample, and therefore, the wider inherent variation of textural properties characteristic of native foods (whole muscle) cannot be limited. Variation in quality characteristics of rainbow trout fillets have been noted (Mørkøre and others 2002). In addition, a threefold change in cutting-shear force was observed within a raw salmon fillet from cranial to caudal ends (Sigurgisladottir and others 1999). In red meat, tough connective tissue and soft fatty tissue determine the correlation between sensory and instrumental texture (Bourne 2002). However, the unique feature of fish muscle is the low connective tissue content and thermal instability of collagen that account for the fillets susceptibility to disintegration upon heating (Dunajski 1979). Therefore, determining collagen content and intermolecular crosslinks is necessary to describe changes in fillet texture.

The low correlation of instrumental texture with individual sensory attributes may lie in the fact that textural quality of food products is an integration of more than one physical property or sensory attribute (Okabe 1979; Kokini and others 1984; Barreiro and others 1998; Daubert and others 1998). To address this issue, the present study attempted to relate instrumental texture data to the principal component score from a combined set of sensory data. However, there was no 
correlation between instrumental texture data and principal component score $(P>0.05)$. Rosenthal (1999) pointed out that texture can arise from multifarious stimuli and that most instrumental measurements tend to concentrate on one property of the food. According to Bourne (2002), a high correlation coefficient does not prove there is a cause-and-effect relationship. Rather, it only means that the variables are changing in unison. Therefore, a precise relationship between an instrumental measurement and the sensory experience could not be assumed.

To summarize, despite a significant storage regimen*panelist effect, PCA showed that sensory measurement in the present study was an effective tool for validating instrumental measurement as it captured significant amount of variance in the data set. Fatness, hardness, and elasticity may be the textural properties best describing trout fillet texture under refrigerated and frozen storage. VB maximum force can be used as a predictor of sensory hardness. AK can be less practically used for predictive purposes of fillet texture. 


\section{CONCLUSION}

The variable-blade attachment could measure effect of shear direction on fillet texture and predict the key texture attribute (hardness). Additional data (e.g., proteolytic activity, collagen thermal property, etc.) is needed to describe the contribution of collagen and myofibrillar protein to fillet texture as measured by the variable-blade attachment. 


\section{REFERENCES}

AOAC. 1990. Official Methods of Analysis. 15th ed. Washington, DC: Association of Official Analytical Chemists.

Ashie INA, Simpson BK. 1997. Proteolysis in food myosystems-a review. J Food Biochem 21:91123.

Ashie INA, Simpson BK. 1998. Effects of pressurization and refrigerated storage on microstructure of fish muscle tissue. J Muscle Foods. 9:193-9.

Bagley E, Christianson D. 1987. Measurement and interpretation of rheological properties of foods. Food Tech 41:96-9.

Barreiro P, Ortiz C, Altisent MR-, DeSmeat V, Schotte S, Andani Z, Wakeling I, Beytes DK. 1998. Comparison between sensory and instrumental measurements for mealiness assessment in apples. a collaborative test. J Texture Stud 29:509-25.

Borderias AJ, Lamua M, Tejada M. 1983. Texture analysis of fish fillets and minced fish by both sensory and instrumental methods. J Food Technol 18:85-95.

Bourne M. 2002. Food texture and viscosity: concept and measurement. 2nd ed. New York: Academic Press. 445 p.

Brannan R G. 2009. Effect of Grape Seed Extract on Descriptive Sensory Analysis and Physical Properties of Ground Chicken During Refrigerated Storage. Meat Science 81:589-95.

Brennan JG. 1980. Food texture measurement. In: King RD, editor. Developments in food analysis techniques. 2nd vol. Essex: Applied Science Publishers. p 1-78.

Cavitt LC, Youm GW, Meullenet JF, Owens CM, Xiong R, 2004. Prediction of poultry meat tenderness using razor blade shear, Allo-Kramer shear, and sarcomere length. J Food Sci 69:11-5.

Cavitt LC, Meullenet J-FC, Xiong R, Owens CM. 2005. The relationship of razor blade shear, Allo-Kramer shear, Warner-Bratzler shear and sensory tests to changes in tenderness of broiler breast fillets. J Muscle Foods. 16:223-42.

Daubert CR, Tkachuk JA, Truong VD. 1998. Quantitative measurement of food spreadability using the vane method. J Texture Stud 29:427-35.

de Huidobro FR, Miguel E, Blazquez B, Onega E. 2005. A comparison between two methods (Warner-Bratzler and texture profile analysis) for testing either raw meat or cooked meat. Meat Sci 69:527-36.

Dobraszczyk BJ, Vincent JFV. 1999. Measurement of mechanical properties of food materials in relation to texture: the materials approach. In: Rosenthal A, editor. Food texture: measurement and perception. $1^{\text {st }}$ ed. Maryland: Aspen Publishers, Inc. p 99-151. 
Dramsfield E, FrancoVBe MA, Whelehan OP. 1984. Relationships between sensory attributes in cooked meat. J Texture Stud 15:33-48.

Dunajski E. 1979. Texture of fish muscle. J Texture Stud 10:301-18.

Foegeding EA, Lanier TC, Hultin HO. 1996. Characteristics of edible muscle tissues. In: Fennema OR, editor. Food chemistry. $3^{\text {rd }}$ ed. New York: Marcel Dekker, Inc. p 879-942.

Food Safety Education: Is It Done Yet? [Internet]. Washington, DC: Food Safety and Inspection Service, United States Department of Agriculture; 2006 May 9 [2010 Mar 13]. Available from: http://www.fsis.usda.gov.

Hair JF, Black B, Babin B, Anderson RE, Tatham RL. 2005. Multivariate Data Analysis, 6th ed. New York: Prentice Hall. 928 p.

Hamm R. 1977. Changes of muscle proteins during the heating of meat. In: Hoyem T, Kvale O, editors. Physical, chemical and biological changes in food caused by thermal processing. Oslo: Applied Science Publishers. p 101-34.

Harris PV, Shorthose WR. 1988. Meat texture. In: Lawrie RA, editor. Developments in meat science. 4th vol. Essex: Elsevier Science Publishing Ltd. p 245-96.

Hernández MD, López VB, Álvarez A, Ferrandini E, García BG, Garrido MD. 2009. Sensory, physical, chemical and microbiological changes in aquacultured meagre (Argyrosomus regius) fillets during ice storage. Food Chem 114:237-45.

Kenward MG, Roger JH. 1997. Small sample inference for fixed effects from restricted maximum likihood. Biometrics. 53:983-97.

Kilcast D. 1999. Sensory techniques to study food texture. In: Rosenthal AJ editor. Food texture: measurement and perception. Maryland: Aspen Publishers, Inc. p 31-64.

Kokini JL, Poole M, Mason P, Miller S, Stier EF. 1984. Identification of key textural attributes of fluid and semi-solid foods using regression analysis. J Food Sci 49:47-51.

Ladrat CD-, Cheret R, Taylor R, Bagnis VV-. 2006. Trends in postmortem aging in fish: understanding of proteolysis and disorganization of the myofibrillar structure. CRC Crit Rev Food Sci Nutr 46:409-421.

Lawless, HT, Heymann, H. 1999. Sensory evaluation of food: principles and practices. Aspen Publishers, Inc., Gaithersburg, MD.

Lee YS, Saha A, Xiong R, Owens CM, Meullenet JF. 2008. Changes in broiler breast fillet tenderness, water-holding capacity, and color attributes during long-term frozen storage. J Food Sci 73:E162-8.

Light ND. 1987. The role of collagen in determining the texture of meat. In: Pearson AM, Dutson TR, editors. Advances in meat research. New York: Van Nostrand Reinhold Company. $p$ 87-107. 
LitteL RC, Milliken GA, Stroup WW, Wolfinger RD, Schabenberger O. 2006. SAS for mixed models. 2nd ed. NC: SAS Institute Inc. 840 p.

Mah E, Brannan RG. 2009. Reduction of oil absorption in deep-fried, battered, and breaded chicken patties using whey protein isolate as a postbreading dip: effect on flavor, color, and texture. J Food Sci 74:S9-16.

McGarigal K, Cushman S, Stafford S. 2000. Multivariate statistics for wildlife and ecology research. New York: Springer. 283 p.

Meilgaard MC, Civille GV, Carr BT. 2006. Sensory Evaluation Techniques, 4th ed. New York: CRC Press LLC. 464 p.

Mørkøre T, Vallet JL, Cardinal M, Guillen MCG, Montero P, Torrissen OJ, Nortvedt R, Sigurgisladottir S, Thomassen MS. 2001. Fat content and fillet shape of Atlantic salmon: relevance for processing yield and quality of raw and smoked products. J Food Sci 66:1348-54.

Mørkøre T, Hansen AA, Unander E, Einen O. 2002. Composition, liquid leakage, and mechanical properties of farmed rainbow trout: variation between fillet sections and the impact of ice and frozen storage. J Food Sci 67:1933-8.

Mørkøre T, Einen O. 2003. Relating sensory and instrumental texture analysis of Atlantic salmon. J Food Sci 68:1492-7.

Nielsen D, Hyldig B, Nielsen J, Nielsen HH. 2005. Liquid holding capacity and instrumental and sensory texture properties of herring (Clupea Harengus L.) related to biological and chemical parameters. J Texture Stud 36:119-38.

Nortvedt R, Tuene S. 1998. Body composition and sensory assessment of three weight groups of Atlantic halibut (Hippoglossus hippoglossus) fed three pellet sizes and three dietary fat levels. Aquaculture 161:295-313.

Ofstad R, Kidman S, Myklebust R, Hermansson AM. 1993. Liquid holding capacity and structural changes during heating of fish muscle: cod (Gadus morhua L.) and salmon (Salmo salar). Food Structure. 12:163-74.

Ofstad R, Egelandsdal B, Kidman S, Myklebust R, Olsen RL, Hermansson AM. 1996. Liquid loss as affected by post-mortem ultrastructural changes in fish muscle: cod (Gadus morhua L.) and salmon (Salmo salar). J Sci Food Agric 71:301-12.

Okabe T. 1979. Texture measurement of cooked rice and its relationship to eating quality. $\mathrm{J}$ Texture Stud 10:131-52.

Olsson GB, Olsen RL, Carlehog M, Ofstad R. 2003. Seasonal variations in chemical and sensory characteristics of farmed and wild Atlantic halibut (Hippoglossus hippoglossus).

Aquaculture. 217:191-205. 
Purslow PP. 1991. Measuring meat texture and understanding its structural basis. In: Vincent JFV, Lillford PJ, editors. Feeding and the texture of food. Cambridge: Cambridge University Press. p 35-56.

Rosenthal A. 1999. Relation between instrumental and sensory measures of food texture. In: Rosenthal A, editor. Food texture: measurement and perception. $1^{\text {st }}$ ed. Maryland: Aspen Publishers, Inc. p 1-17.

SAS Institute Inc. 2004. SAS/STAT ${ }^{\circledR} 9.1$ user's guide. 1st ed. NC: SAS Publishing. 5136 p.

SAS Institute Inc. 2005. JMP ${ }^{\circledR}$ for basic univariate and multivariate statistics: a step-by-step guide. 1st ed. NC: SAS Publishing. 481 p.

Schubring R. 2008. Comparative study of the DSC pattern, color, texture and water-binding capacity of rainbow trout muscle during heating. J Food Process Preserv 32:190-218.

Sigurgisladottir S, Hafsteinsson A, Jenssen A, Lie O, Nortviet R, Thomassen M, Torrissen O. 1999. Textural properties of raw salmon fillets as affected by sampling method. J Food Sci 64:99-104.

Sikorski ZE, Scott DN, Buisson DH. 1984. The role of collagen in the quality and processing of fish. CRC Crit Rev Food Sci Nutr 20:301-43.

Smith DP, Fletcher DL. 1998. Effects of broiler breast meat fiber direction, dicing, and postmortem deboning time on Allo-Kramer Shear. J Appl Poult Res 7:281-6.

Stanley DW, Swatland HJ. 1976. The microstructure of muscle tissue - a basis for meat texture measurement. J Texture Stud 7:65-75.

Swatland HJ. 1978. Microstructure of cuts through the connective tissue framework of meat. J Inst Can Sci Technol Aliment 11:204-8.

Szczesniak AS, Torgeson K. 1965. Methods of meat texture measurement viewed from the background of factors affecting tenderness. Adv Food Res 14:33-165.

Taylor RG, Fjaera S, Skjervold PO. 2002. Salmon fillet texture is determined by myofibermyofiber and myofiber-myocommata attachment. J Food Sci 67:2067-71.

Tornberg E. 1996. Biophysical aspects of meat tenderness. Meat Science. 43:S175-91.

Xiong R, Cavitt LC, Meullenet JF, Owens CM. 2006. Comparison of Allo-Kramer, WarnerBratzler and razor blade shears for predicting sensory tenderness of broiler breast meat. J Texture Stud 37:179-99.

Xiong YL. 1997. Protein denaturation and functionality losses. In: Erickson MC, Hung YC, editors. Quality in frozen food. New York: Chapman \& Hall. p 111-40. 

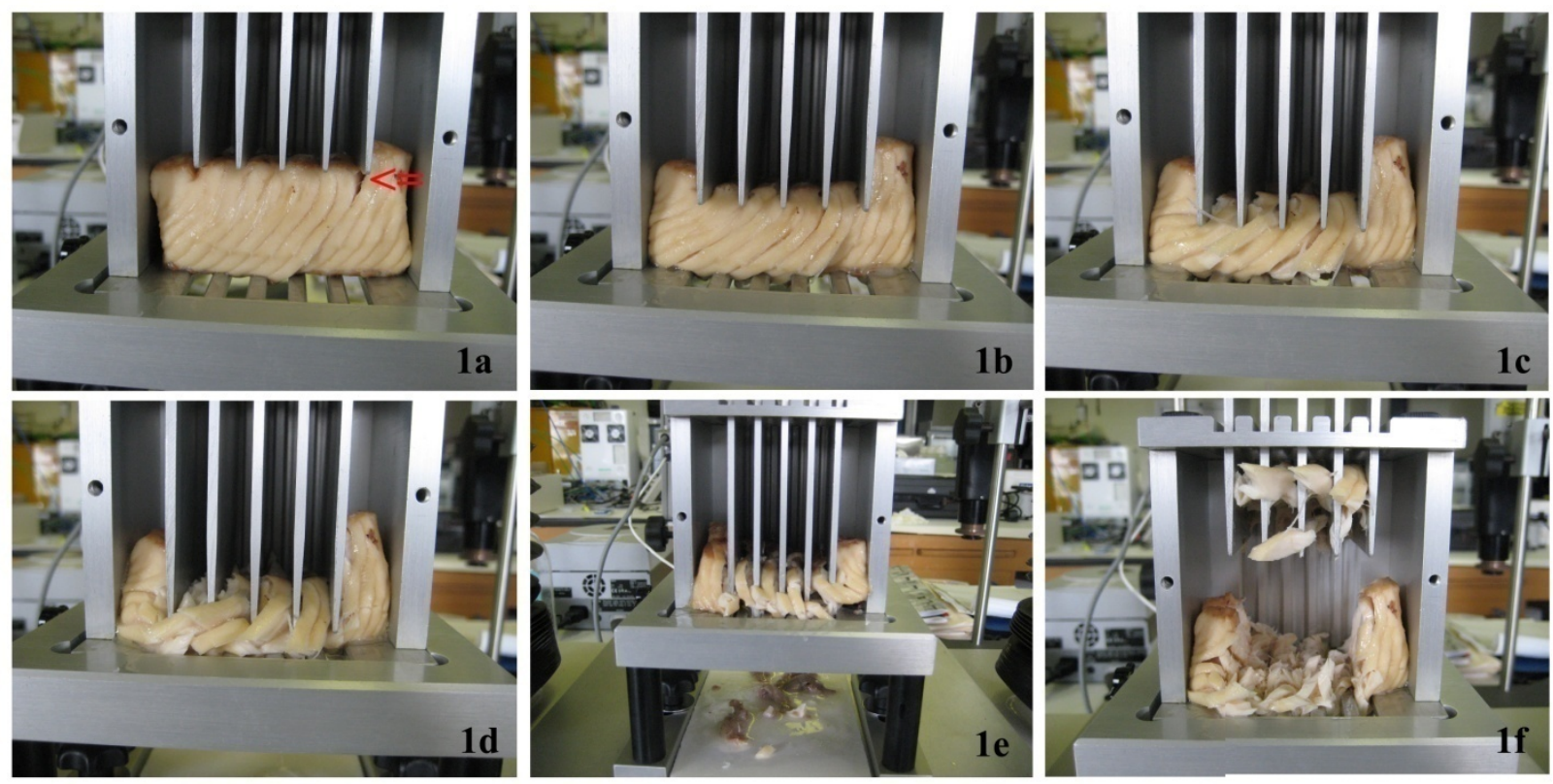

Figure 1 - Deformation of cooked fillet by Allo-Kramer shear attachment. Pressing of five blades on the fillet causes separation of muscle segments (myotomes) which are hold together by thin sheath of connective tissue (myocommata). Fillet sample begins to disintegrate as the five blades touch at the top (1a). Initial point of separation is indicated by an arrow. Several separations of myotome-myocommanta-myotome junction cause myotomes to slip down, and eventually fillet structure collapses (1b and 1c). The five blades shear through a bulk collection of muscle fiber before passing through a slotted plate (1d and 1e). Blades remove from a slotted cage leaving the fillet sample completely destroyed (1f). 


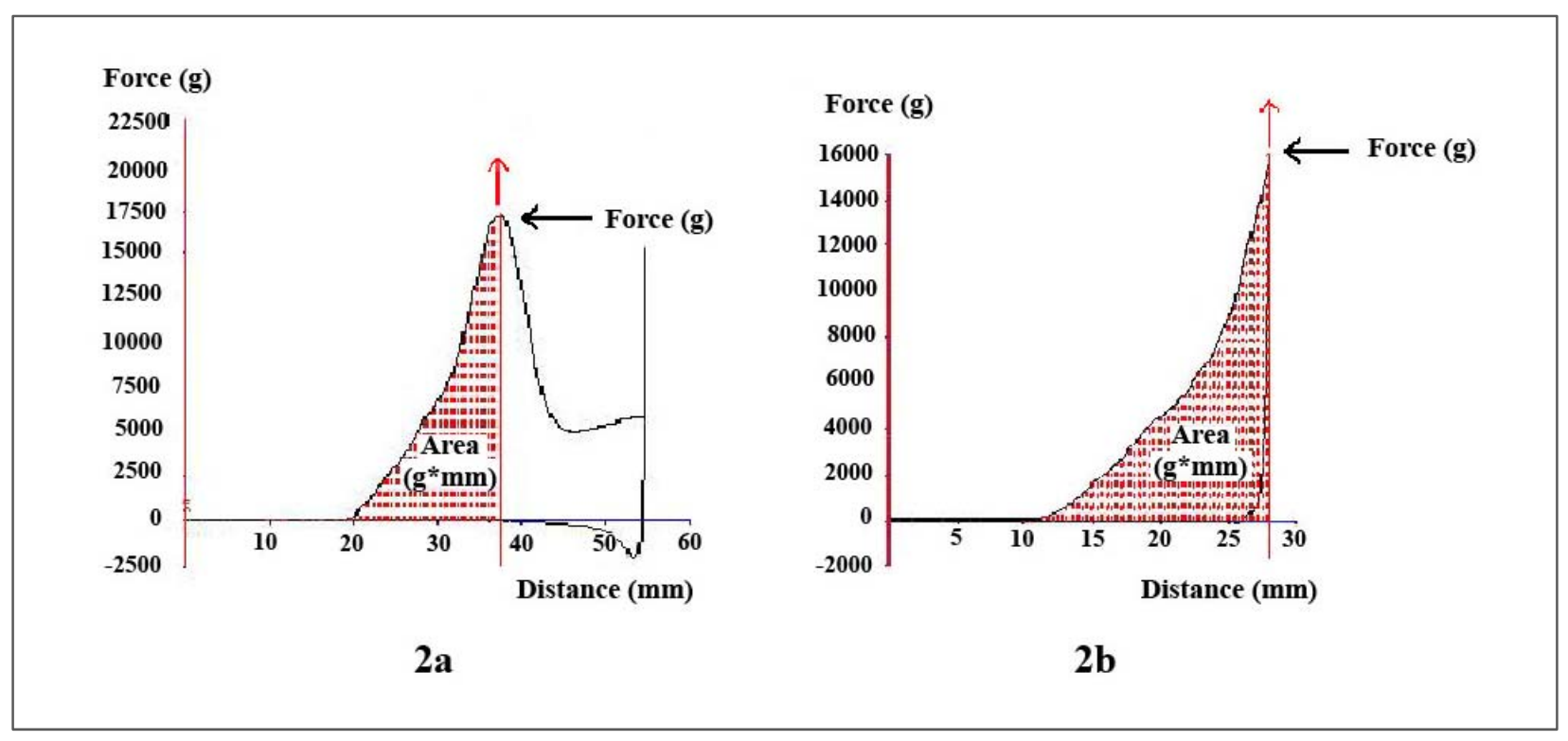

Figure 2 -Force-deformation curves for calculation of maximum shear force (g) and area (g*mm) generated by Allo-Kramer (2a) and variable blade attachment (2b). Calculation of area under the curve started from $0 \mathrm{~g}$ force to the maximum value. 

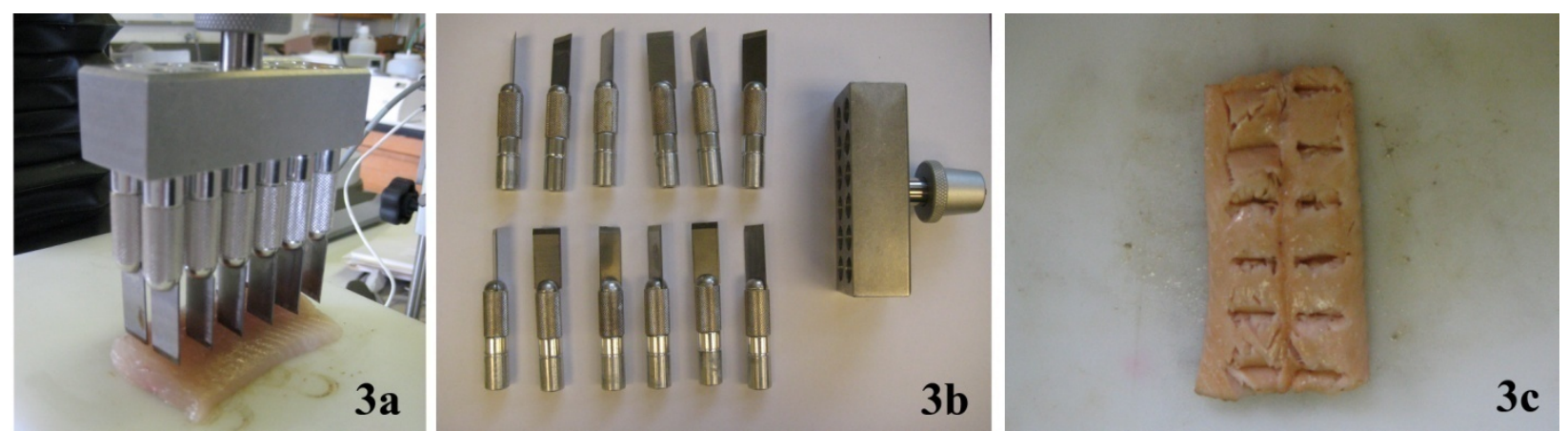

Figure 3 - Variable-blade attachment (VB) with 12 blades arranged in perpendicular direction to muscle fiber (3a), removable blades and the holder (3b), and a top view of cooked fillet after a perpendicular shear (3c). 
Table 1 Description and anchored references of sensory attributes generated by descriptive analysis of trout fillets subjected to different storage regimens.

\begin{tabular}{|c|c|c|c|}
\hline Attribute & Description & Reference/Brand/Preparation & $\begin{array}{l}\text { Position } \\
(\mathrm{cm})^{1}\end{array}$ \\
\hline Hardness & $\begin{array}{l}\text { The force that is required to bite } \\
\text { through the sample with incisors }\end{array}$ & $\begin{array}{l}\text { Cream cheese, Kraft, } \\
\text { Philadelphia Light, } 1 / 2 \text { in cube } \\
\text { Egg white, hard-cooked, } 1 / 2 \text { in } \\
\text { cube } \\
\text { Cheese, American, } 1 / 2 \text { in slice } \\
\text { Frankfurter/Hebrew } \\
\text { national }{ }^{\circledR} / \text { large, cooked } 5 \mathrm{~min} / \\
1 / 2 \text { in slice } \\
\text { Peanuts/ Planters }{ }^{\circledR} / \text { cocktail type }^{-}\end{array}$ & $\begin{array}{l}1.0 \\
2.5 \\
4.5 \\
7.0 \\
9.5\end{array}$ \\
\hline $\begin{array}{l}\text { Elasticity } \\
\text { (Springiness) }\end{array}$ & $\begin{array}{l}\text { The degree to which the sample } \\
\text { returns to original shape when } \\
\text { partially compressed with the } \\
\text { molar teeth }\end{array}$ & $\begin{array}{l}\text { Cream cheese, Kraft, } \\
\text { Philadelphia } \\
\text { Frankfurter/Hebrew } \\
{\text { national }{ }^{\circledR} / \text { large, cooked } 5 \mathrm{~min} /}_{1 / 2 \text { in slice }} \\
\text { Marshmallow, miniature } \\
\text { Jello }\end{array}$ & $\begin{array}{l}0.0 \\
5.0 \\
9.5 \\
15.0\end{array}$ \\
\hline $\begin{array}{l}\text { Juiciness } \\
\text { (moisture } \\
\text { release) }\end{array}$ & $\begin{array}{l}\text { The amount of moisture released } \\
\text { during a predetermined number } \\
\text { of chews }\end{array}$ & $\begin{array}{l}\text { Carrot/ } 1 \text { inch cubes } \\
\text { Mushroom/button/quartered } \\
\text { Snap beans } / 1 / 2 \text { inch pieces }\end{array}$ & $\begin{array}{l}2.0 \\
4.0 \\
7.0\end{array}$ \\
\hline $\begin{array}{l}\text { Fatness (oily } \\
\text { mouth coating) }\end{array}$ & $\begin{array}{l}\text { The amount of oily coating that is } \\
\text { perceived in the mouth cavity } \\
\text { after the sample has been } \\
\text { swallowed or expectorated }\end{array}$ & $\begin{array}{l}\text { Cold fries/Ore-Ida }{ }^{\circledR} \text { Golden } \\
\text { Fries/deep-fried, cooled to } \\
\text { room temperature }\end{array}$ & 6.0 \\
\hline Coarseness & $\begin{array}{l}\text { The degree to which the sample } \\
\text { breaks apart upon chewing with } \\
\text { the molar teeth after a } \\
\text { predetermined amount of chews. }\end{array}$ & $\begin{array}{l}\text { Vienna Sausage, } 1 / 2 \text { inch slice } \\
\text { Beef Jerky, small piece }\end{array}$ & $\begin{array}{l}0.5 \\
13.0\end{array}$ \\
\hline
\end{tabular}

${ }^{1}$ Position on $15-\mathrm{cm}$ line scale

${ }^{2}$ Generated by descriptive analysis panel 


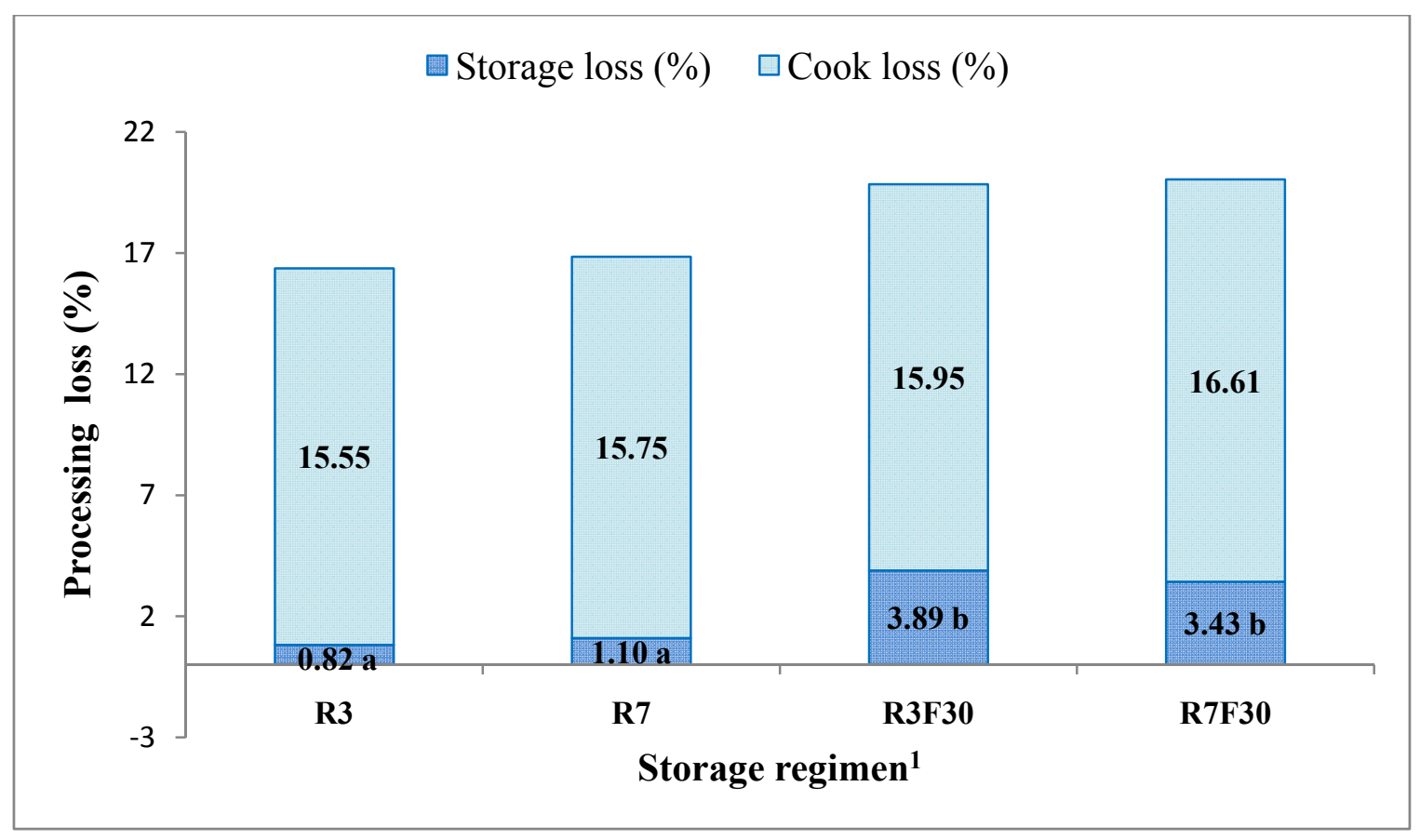

Figure 4 - Processing loss (\%) for fillets stored under different storage regimens. ${ }^{\text {a,b }}$ Means (standard error; storage loss $=0.24$ and $\operatorname{cook} \operatorname{loss}=\mathbf{0 . 3 4}$ ) with different letters within the same response are different $(P<0.05 ; \mathrm{N}=18) .{ }^{1} \mathrm{R} 3$ : refrigeration at $2{ }^{\circ} \mathrm{C}$ for 3 days; $\mathrm{R} 7$ : refrigeration for 7 days; R3F30: refrigeration for 3 days followed by frozen storage at $-25{ }^{\circ} \mathrm{C}$ for 30 days; R7F30: refrigeration for 7 days followed by frozen storage for 30 days. 
Table 2 - Mean pH, moisture, and fat content of raw and cooked fillets.

\begin{tabular}{cccccc}
\hline \multirow{2}{*}{$\begin{array}{c}\text { Storage } \\
\text { regimen }\end{array}$} & Raw pH & \multicolumn{2}{c}{ Moisture (\%) } & \multicolumn{2}{c}{ Fat (\%) } \\
\cline { 2 - 5 } & & Raw & Cooked & Raw & Cooked \\
\hline R3 & 6.56 & $69.20^{\mathrm{b}}$ & $65.28^{\mathrm{a}}$ & 10.00 & 10.92 \\
\hline R7 & 6.57 & $68.48^{\mathrm{b}}$ & $65.14^{\mathrm{a}}$ & 11.18 & 10.21 \\
\hline R3F30 & 6.64 & $69.20^{\mathrm{b}}$ & $64.93^{\mathrm{a}}$ & 10.42 & 10.56 \\
\hline R7F30 & 6.54 & $69.61^{\mathrm{b}}$ & $64.71^{\mathrm{a}}$ & 9.93 & 10.06 \\
\hline
\end{tabular}

${ }^{\mathrm{a}, \mathrm{b}}$ Means (standard error; $\mathrm{pH}=0.03$, moisture $=0.45$, and fat $=0.58$ ) with different letters within the same response are different $(P<0.05 ; \mathrm{N}=6) .{ }^{1} \mathrm{R} 3$ : refrigeration at $2{ }^{\circ} \mathrm{C}$ for 3 days; $\mathrm{R} 7$ : refrigeration for 7 days; R3F30: refrigeration for 3 days followed by frozen storage at $-25{ }^{\circ} \mathrm{C}$ for 30 days; R7F30: refrigeration for 7 days followed by frozen storage for 30 days. 


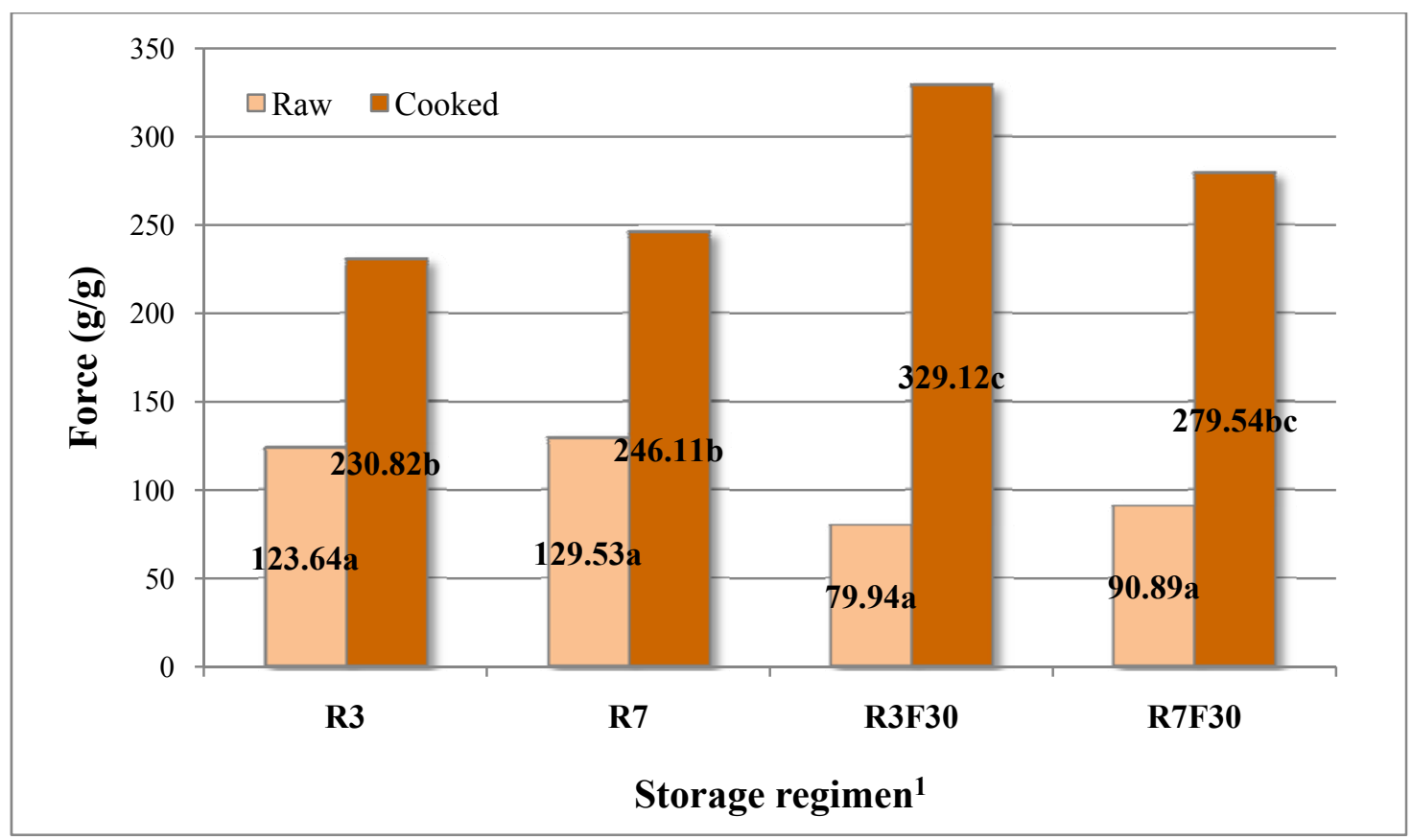

Figure 5 - Maximum force (g/g) determined by variable blade with all 12 blades arranged in perpendicular direction to muscle fiber (VB). ${ }^{\text {a,b,c }}$ Means (standard error=19.33) with different letters within the same response are different $(P<0.05 ; N=6)$. ${ }^{1} \mathrm{R3}$ : refrigeration at 2 ${ }^{\circ} \mathrm{C}$ for 3 days; R7: refrigeration for 7 days; R3F30: refrigeration for 3 days followed by frozen storage at $-25^{\circ} \mathrm{C}$ for 30 days; R7F30: refrigeration for 7 days followed by frozen storage for 30 days. Cooked samples were fresh (raw) fillets cooked until their internal temperature reached $65.5{ }^{\circ} \mathrm{C}$. Both raw and cooked fillets were analyzed at room temperature. 


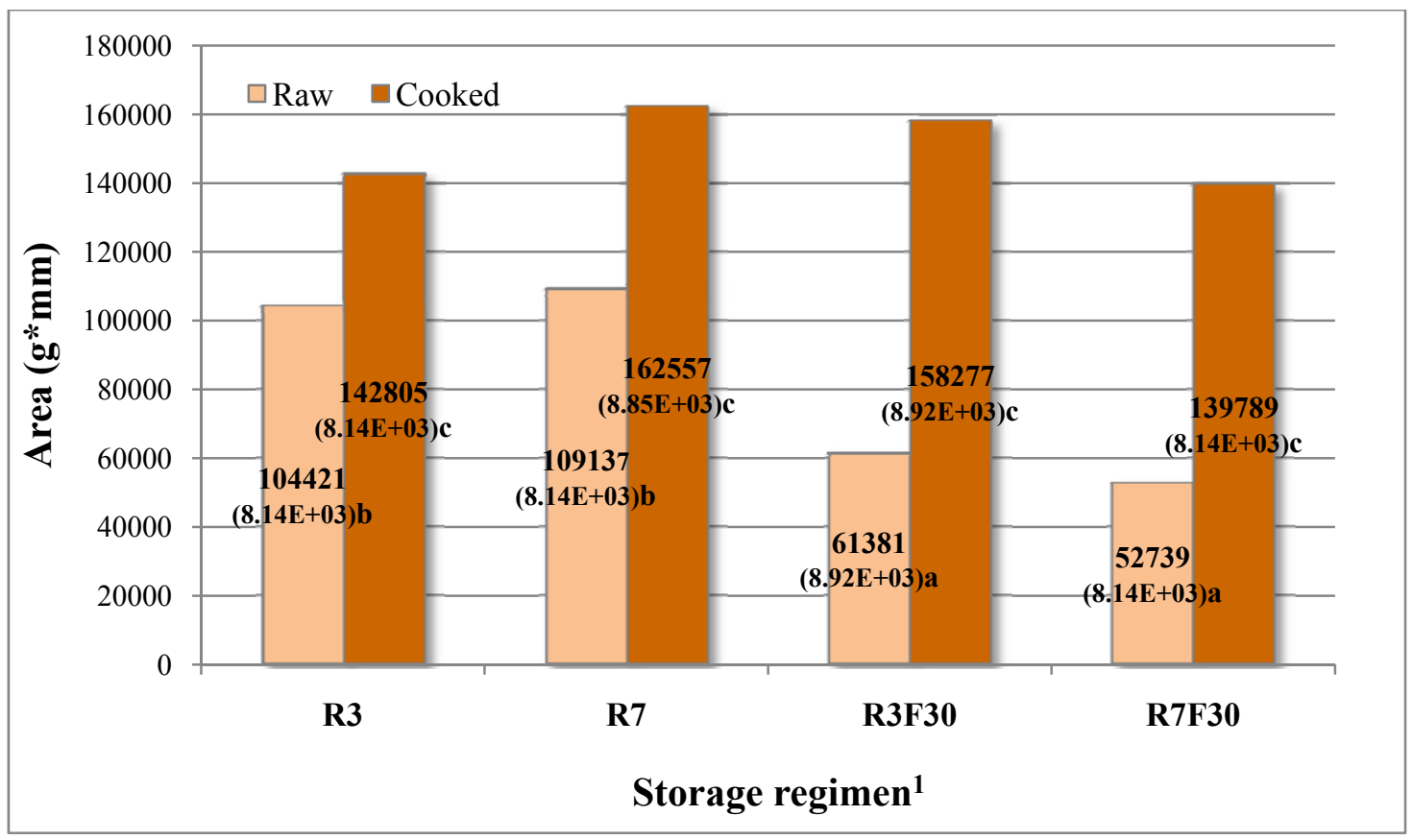

Figure 6 - Area or energy of shear $\left(g^{*} \mathrm{~mm}\right)$ determined by Allo-Kramer (AK). ${ }^{\text {a,b,c }}$ Means (standard error) with different letters within the same response are different $(P<0.05) . \quad N=6$. ${ }^{1} \mathrm{R} 3$ : refrigeration at $2{ }^{\circ} \mathrm{C}$ for 3 days; R7: refrigeration for 7 days; R3F30: refrigeration for 3 days followed by frozen storage at $-25{ }^{\circ} \mathrm{C}$ for 30 days; R7F30: refrigeration for 7 days followed by frozen storage for 30 days. Cooked samples were fresh (raw) fillets cooked until their internal temperature reached $65.5{ }^{\circ} \mathrm{C}$. Both raw and cooked fillets were analyzed at room temperature. 
Table 3 - Mean sensory attribute score of cooked fillets received different storage regimens

\begin{tabular}{cccccc}
\hline \multirow{2}{*}{$\begin{array}{c}\text { Storage } \\
\text { regimen }^{1}\end{array}$} & \multicolumn{5}{c}{ Sensory attributes $^{2}$} \\
\cline { 2 - 6 } & Hardness & Elasticity & Juiciness & Fatness & Coarseness \\
\hline $\mathbf{R 3}$ & 2.67 & $2.75^{\mathrm{a}}$ & 3.87 & 3.24 & 4.54 \\
\hline $\mathbf{R} 7$ & 3.59 & $3.38^{\text {ab }}$ & 3.70 & 2.58 & 5.27 \\
\hline $\mathbf{R 3 F 3 0}$ & 3.88 & $4.52^{\mathrm{c}}$ & 2.99 & 2.78 & 5.97 \\
\hline $\mathbf{R} 7 F 30$ & 3.17 & $3.97^{\mathrm{bc}}$ & 3.41 & 3.01 & 5.72 \\
\hline
\end{tabular}

${ }^{\mathrm{a}, \mathrm{b}}$ Means (standard error; hardness $=0.46$, elasticity $=0.61$, juiciness $=0.78$, fatness $=0.44$, and coarseness $=0.59)$ with different letters within the same response are different $(P<0.05 ; \mathrm{N}=6) .{ }^{1} \mathrm{R} 3$ :

refrigeration at $2{ }^{\circ} \mathrm{C}$ for 3 days; R7: refrigeration for 7 days; R3F30: refrigeration for 3 days followed by frozen storage at $-25^{\circ} \mathrm{C}$ for 30 days; R7F30: refrigeration for 7 days followed by frozen storage for 30 days. ${ }^{2}$ Hardness: the force required to bite through the sample with incisors; Juiciness: the amount of moisture released during a predetermined number of chews; Elasticity: the degree to which the sample returned to its original shape after it was compressed partially with the molars; Fatness: the amount of oily coating that was perceived in the mouth cavity after the sample had been swallowed or expectorated; Coarseness: the feeling of large coarse fibers in the mouth. 


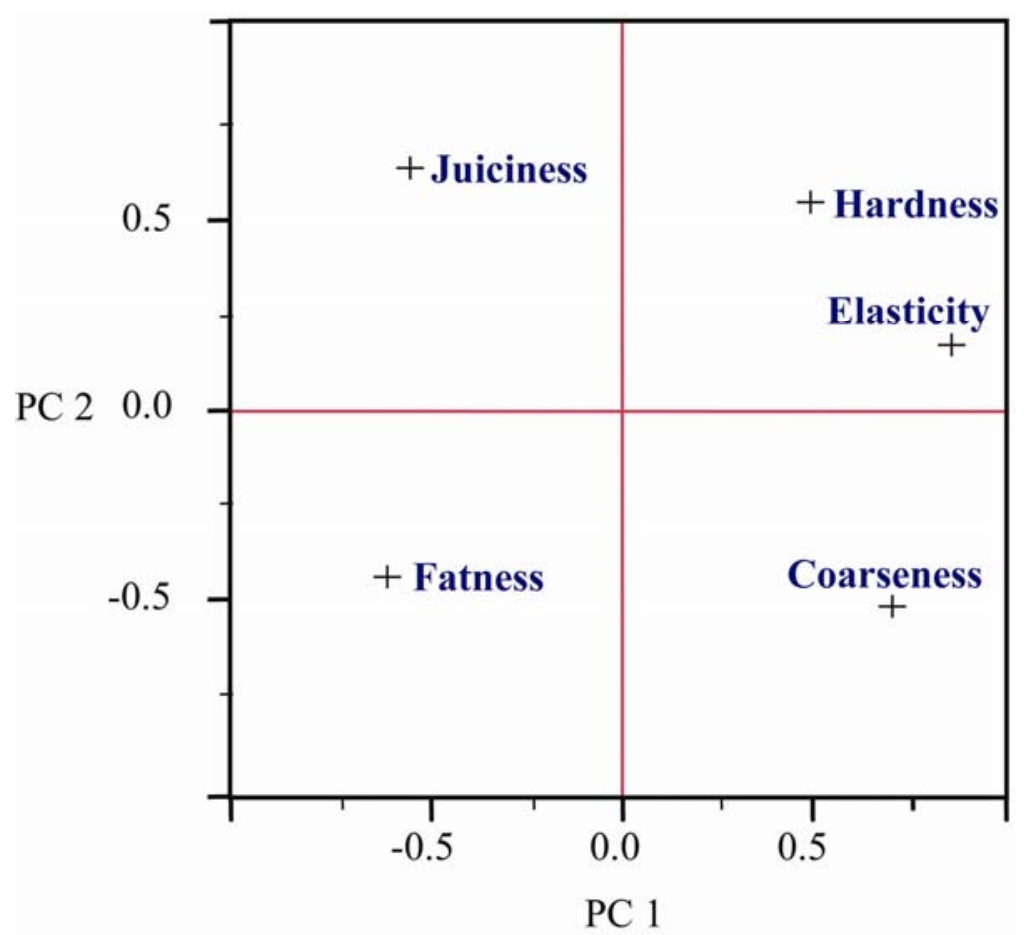

Figure 7 - Loading plot of five sensory attributes on principal component axes. The first (PC1) and the second (PC2) axis explained $44 \%$ and $22 \%$ of the total variance, respectively. Sensory attributes include hardness (the force required to bite through the sample with incisors), juiciness (the amount of moisture released during a predetermined number of chews), elasticity (the degree to which the sample returned to its original shape after it was compressed partially with the molars), fatness (the amount of oily coating that was perceived in the mouth cavity after the sample had been swallowed or expectorated), and coarseness (the feeling of large coarse fibers in the mouth). 
Table 4 - Pearson correlation coefficient ( $r$ ) between instrumental texture measurements and processing losses and sensory attribute scores of cooked fillets.

\begin{tabular}{|c|c|c|c|c|c|c|c|}
\hline \multirow{2}{*}{$\begin{array}{c}\text { Instrumental } \\
\text { Texture }^{1}\end{array}$} & \multirow{2}{*}{$\begin{array}{c}\text { Storage } \\
\text { loss }\end{array}$} & \multirow{2}{*}{$\begin{array}{c}\text { Cook } \\
\text { loss }\end{array}$} & \multicolumn{5}{|c|}{ Sensory attributes $^{2}$} \\
\hline & & & Hardness & Elasticity & Juiciness & Fatness & Coarseness \\
\hline \multicolumn{8}{|l|}{ Force } \\
\hline $\mathrm{AK}$ & $0.498^{*}$ & 0.291 & 0.064 & 0.081 & 0.121 & -0.015 & 0.089 \\
\hline VB & 0.180 & $0.412 *$ & $0.423 *$ & -0.046 & 0.096 & -0.110 & 0.182 \\
\hline VBPAR & 0.262 & $0.504 *$ & -0.229 & -0.111 & 0.069 & 0.031 & 0.041 \\
\hline \multicolumn{8}{|l|}{ Area } \\
\hline AK & 0.049 & 0.247 & -0.030 & -0.119 & 0.177 & 0.041 & 0.061 \\
\hline VB & -0.059 & -0.201 & 0.306 & -0.039 & -0.010 & -0.114 & 0.036 \\
\hline VBPAR & ND & ND & ND & ND & ND & ND & ND \\
\hline
\end{tabular}

${ }^{1}$ AK: Allo-Kramer; VB: variable blade; PER: blade arrangement in perpendicular direction to muscle fiber; PAR: blade arrangement in parallel direction.

${ }^{2}$ Hardness: the force required to bite through the sample with incisors; Juiciness: the amount of moisture released during a predetermined number of chews; Elasticity: the degree to which the sample returned to its original shape after it was compressed partially with the molars; Fatness: the amount of oily coating that was perceived in the mouth cavity after the sample had been swallowed or expectorated; Coarseness: the feeling of large coarse fibers in the mouth. 


\section{CHAPTER 2}

Effect of sexual maturation on growth, fillet composition, and texture of female rainbow trout (Oncorhynchus mykiss) on a high nutritional plane 


\begin{abstract}
Nutrient and energy demands of sexual maturation influence fillet composition and texture in many fish cultivars. Effects of sexual maturation on growth and on fillet composition and texture were investigated in rainbow trout on a high nutritional plane. Diploid ( $2 \mathrm{~N}$; fertile) and triploid (3N; sterile) female rainbow trout were reared from July 2008 through spawning in March 2009. Growth rates were greater in the $2 \mathrm{~N}$ females from August through October; whereas, the reverse response was true in February and March, resulting in similar overall growth rates and body weight $(3140 \pm 76 \mathrm{~g})$. Raw fillets were softer, regardless of ploidy, between September and January (Allo-Kramer shear) compared to July, but increased again in March (366.79 g/g). By November, $2 \mathrm{~N}$ females had lower fillet fat content and higher moisture content than $3 \mathrm{~N}$ females. Fat content negatively correlated with shear force $\left(r=-0.35, \mathrm{R}^{2}=0.12\right)$. Alkaline-insoluble (a-i) hydroxyproline (HYP) concentration was similar for $2 \mathrm{~N}$ and $3 \mathrm{~N}$ muscle through January but increased 2 and 4 fold for $3 \mathrm{~N}$ and $2 \mathrm{~N}$ muscle, respectively, by March. A-i HYP positively correlated with energy of shear $\left(\mathrm{r}=0.41, \mathrm{R}^{2}=0.17\right)$. In summary, during the five months prior to spawning and in females on a high nutritional plane, increased accumulation of fat in $3 \mathrm{~N}$ females resulted in decreased firmness of raw fillets; whereas, increased insoluble collagen content, primarily in $2 \mathrm{~N}$ females, increased fillet firmness in the month of spawning.
\end{abstract}

Keywords: Rainbow trout, texture, sexual maturation, ploidy, collagen 


\section{INTRODUCTION}

Feeding rates leading to deterioration of fillet texture during sexual maturation are undesirable in aquaculture when the fish are to be sold for consumption (Piferrer et al., 2009), but preferred for egg production in rainbow trout (Gutsell, 1940). Rainbow trout grown past the age of onset of gonadal maturation and intended for consumption are usually triploid $(3 \mathrm{~N})$ fish that are sterile and do not develop gonads. For these reasons, limited studies investigating effects of sexual maturation on muscle composition and fillet texture in rainbow trout have been conducted on fish at a low nutritional plane. Nevertheless, to gain a greater understanding of factors causing changes in muscle catabolism and texture during maturation, and how they are regulated, it is advantageous to investigate these muscle quality changes in fish in which nutrients are maximized. Such an approach was taken in the present study to facilitate identification of possible, developmentallyregulated changes in nutrient partitioning and muscle composition.

All factors affecting fillet quality (i.e. muscle tissue composition and fiber growth), including sexual maturation, are complex and under control of genetic-by-environment interactions (Kiessling et al., 2006). Maturation associated deterioration in flesh quality is due in part to muscle atrophy associated with protein catabolism when energy and nutrients required for gonadal development are beyond non-muscle nutrient reserves and diet. Previous studies on fish with low nutritional support showed that atrophying muscle of diploid $(2 \mathrm{~N})$ trout at spawning had $11 \%$ less separable muscle and $11 \%$ lower protein content and higher protein catabolism compared with non-atrophying muscle of 3N fish (Salem et al., 2006 a,b). Sexual-maturation- induced proteolysis in muscle has been reported for several fish species, including salmonids (Yamashita and Konagaya, 1990; Toyohara et al., 1991; Kubota et al., 2000). Lysosomal cathepsins, particularly 
cathepsin-L, were identified as key proteases in spawning-induced proteolysis of rainbow trout musculature (Salem et al., 2006a). In trout, there is limited information describing changes in fillet texture associated with spawning-induced, muscle protein catabolism. During post mortem storage of cod, cathepsin D was associated with myosin heavy chain degradation (Wang et al., 2009). Nevertheless, collagenase activity rather than proteolysis of myofibrils was determined to be the major cause of muscle softenting during ice storage in this species (Hernández-Herrero et al., 2003).

Variation in muscle cellularity and associated changes in connective tissue matrix are thought to be important determinants of texture and other flesh quality characteristics in most animals (Johnston, 1999; Hagen 2007). In general, degree of collagen insolubility and cross-link content is positively correlated with fillet firmness (Sato et al., 1986a; Montero and Borderías, 1990a; Touhata et al., 2000; Shigemura et al., 2003; Li et al., 2005; Hagen et al., 2007). Furthermore, collagen insolubility in salmon muscle was induced by starvation (Gomez-Guillen et al., 2000). In trout muscle, connective tissue in larger fish (1800g) was more abundant, and the collagen exhibited a lower level of crosslinking than other size groups (200, 800, and 1200g); however, significant difference in hardness values for the muscle connective tissue at different points along the fillets was observed only for the youngest specimens (200g) (Montero and Borderías, 1990c).

During a period of nutritional stress such as spawning migration and starvation, lipid content of fillets from fatty fish, including rainbow trout, varies considerably (Hyldig and Nielsen, 2007). Sexual maturation induced an increase in fatty acid utilization by rainbow trout, white muscle (Kiessling et al., 1995). Love (1988) reported that fatty fish use considerable amounts of muscle protein during a period of nutritional stress that includes spawning, migration, and 
starvation. Lipids play a key role in the spawning life of salmonids and are consumed to power upstream migration; they provide energy for reproductive activity, though their contribution, relative to protein, is usually diminished during this latter phase of spawning (Williams et al., 1986; McVeigh et al., 2007).

The present study was conducted to determine changes in fillet composition and the relationship between these changes and texture of fillet from fertile (diploid, $2 \mathrm{~N}$ ) and sterile (fertile, $3 \mathrm{~N}$ ) female rainbow trout on a high nutritional plane and during the normal time of sexual maturation in diploids. Comparisons of fertile $2 \mathrm{~N}$ with sterile $3 \mathrm{~N}$ fish, which do not exhibit significant ovarian development, were used to separate environmental and seasonal changes from those changes due to gonad growth. As an example, season was a dominant factor explaining variation in flesh quality of triploid and diploid Atlantic salmon (Bjørnevik et al., 2004). Fish on a high nutritional plane, having large fat stores and fed to satiation during the study, were used to minimize effects of energy shortfall on fillet quality traits. The results of this present study will benefit the aquatic food industry in developing management strategies and selecting harvest ages for optimum fish growth, fillet yield, and fillet quality in larger fertile and sterile female rainbow trout. 


\section{MATERIALS AND METHODS}

\subsection{Fish material and rearing condition}

Eggs and sperm were collected from two rainbow trout families reared at the National Center for Cool and Cold Water Aquaculture (NCCCWA; U.S. Department of Agriculture, Agricultural Research Service) in Leetown, West Virginia; these stocks were obtained two generations earlier from Troutlodge Inc. (Sumner, WA). Eggs were collected from two, two-yearold females, and eggs from each female were fertilized with sperm from a neomale (genetic female sex reversed with $17 \alpha$-methyltestosterone into a phenotypic male; Cousin-Gerber et al. 1989) of the same stock. Triploid induction was accomplished by applying 9,000 psi $\left(633 \mathrm{~kg} / \mathrm{in}^{2}\right)$ of hydrostatic pressure for eight minutes to a subset of the eggs from each cross for thirty minutes post fertilization (Palti et al., 1997). Fish were confirmed as $2 \mathrm{~N}$ or $3 \mathrm{~N}$ by flow cytometry (Allen, 1983; Hershberger and Hostuttler, 2007). Embryos were incubated at $10 \pm 0.5^{0} \mathrm{C}$, and abnormalities were removed through first feeding. At approximately $50 \mathrm{~g}$, fish were individually tagged using passive integrator transponder (PIT) tags that carry a unique identification number in order to monitor individuals. The PIT tags were placed in the dorsal musculature on the right side of the dorsal fin. Fish care and experimentation followed the guidelines outlined by the USDA and NCCCWA Animal Care and Use Committee, which are in line with the National Research Council publication Guide for Care and Use of Laboratory Animals.

In May 2008, fish were placed in five, randomly assigned tanks (122-cm diameter). They were fed with a commercial feed, Zeigler GOLD Floating $5.0 \mathrm{~mm}\left(3 / 16^{\prime \prime}\right)$ pelleted feed produced by Zeigler Brothers, Inc.; Gardners, Pennsylvania, U.S.A. throughout the course of the experiment. The feed contained 42,16 , and $2 \%$ crude protein, fat, and fiber, respectively. Fish were fed on a 
tank-by-tank basis daily by a belt feeder. The amount of feed was altered depending on appetite. At the end of each day, fish were fed by hand to apparent satiation. This feeding regimen is indicative of a high plane of nutrition. Each of the five tanks was stocked with thirty-five fish, totaling 175 fish for this study. The thirty-five fish assigned to each tank consisted of about the same number of fish of each ploidy $(2 \mathrm{~N}$ and $3 \mathrm{~N})$ from each family. Water was continuous-flow groundwater, with ambient temperatures ranging between $12^{\circ} \mathrm{C}$ and $13.5^{\circ} \mathrm{C}$, and dissolved oxygen content was near air saturation. Photoperiod was maintained with artificial lighting, which was adjusted weekly to follow the ambient photoperiod. At each of six sampling periods, fish were shifted to a different tank to further reduce bias associated with tank.

\subsection{Growth and maturation measurement}

Individual body weights were monitored every month after anaesthetization with $150 \mathrm{mg} / \mathrm{L}$ tricaine methanesulfonate (tricaine-S; Western Chemical, Inc., Ferndale, WA, U.S.A.). Live weight of individual tagged fish was collected monthly, and specific growth rate (SGR) was calculated according to Foss et al. (2009); SGR $=\left(e^{\mathrm{g}}-1\right) 100$ where $\mathrm{g}=\left(\ln \left(\mathrm{W}_{2}\right)-\ln \left(\mathrm{W}_{1}\right)\right)\left(\mathrm{t}_{2}-\mathrm{t}_{1}\right) ; \mathrm{W}_{2}$ and $\mathrm{W}_{1}$ are weights on day's $\mathrm{t}_{2}$ and $\mathrm{t}_{1}$, respectively.

Five fish from each of 2 family by 2 ploidy ( $2 \mathrm{~N}$, fertile; and $3 \mathrm{~N}$, sterile) combinations ( 5 fish $\mathrm{x} 4$ combinations $=20$ fish) were sampled at six ages that were July, September, November, and December 2008; and January and March 2009. These six sampling points marked age endpoints of 16, 18, 20, 21, 22, and 24 months post hatching, respectively. Fish were held off feed 24 hours prior to sampling and were anesthetized using tricaine-S at the NCCCWA. Whole body weight $(\mathrm{g})$ and fork length $(\mathrm{cm})$ were recorded for each fish each month. Evisceration was performed manually. Gonad and visceral weight (g) were recorded. Gonadosomatic index (GSI) 
was calculated as GSI $=\left(\mathrm{W}_{\mathrm{G}} / \mathrm{W}_{\mathrm{B}}\right) \times 100$, where $\mathrm{W}_{\mathrm{G}}$ is gonad weight and $\mathrm{W}_{\mathrm{B}}$ is whole body weight in grams. Empty body weight (EBW) was the body weight excluding digestive tract contents, heart and gonads. Condition factor (CF) was calculated according to Williams (2000); CF = $\left(\left(\mathrm{WBW} \times 10^{5}\right) / \mathrm{L}^{3}\right)$ where WBW is whole body weight $(\mathrm{g})$ and $\mathrm{L}$ is fork length $(\mathrm{cm})$. Abdominal wall thickness was the average of abdominal wall thickness measurement at the ventral middle line taken from three locations including 1) caudal behind the pectoral fin, 2) caudal behind the pelvic fin, and 3) at the vent just before the anal fin. Fish were stored on ice for $3.5 \mathrm{hr}$ for delivery to Morgantown, WV. Fish were subsequently stored in coolers, packed with ice, overnight; they were filleted approximately 18 hours after harvest.

\subsection{Fillet yield and quality analyses}

Viscera and separable muscle weights were collected for each fish. Visceral weight was calculated as a percent of WBW. Separable muscle weight was calculated as either a percent of WBW or a percent of EBW. Fresh fillet surface color was recorded with a chromameter (Minolta, Model CR-300; Minolta Camera Co., Osaka, Japan). This instrument was color calibrated using a standard white plate No. 21333180 (CIE Y 93.1; x 0.3161; y 0.3326), and L* (lightness), a* (redness), and $b^{*}$ (yellowness) values were recorded on the cranial and caudal ends of the fillet. Duplicate measurements were made per fish.

A $40 \times 80 \mathrm{~mm}$ muscle section, devoid of skin, was removed from randomly selected sides for texture analysis. This muscle sample was taken from the dorsal musculature $2-3 \mathrm{~cm}$ caudal to the pectoral girdle. Weight and dimension of the section were recorded prior to cooking. Texture measurement of fillet section was performed using a 5-blade, Allo-Kramer shear attachment mounted to the TA-HDi ${ }^{\circledR}$ Texture Analyzer (Texture Technologies Corp., Scarsdale, NY, U.S.A.), 
equipped with a 50-kg load cell, at a crosshead speed of $127 \mathrm{~mm} / \mathrm{min}$. The shear force was applied transversely to the longitudinal axis of the muscle sections. Force-distance graphs were recorded and analyzed using the Texture Expert Exceed software (version 2.60; Stable Micro Systems Ltd., Surrey, U.K.). Parameters, determined from the graph included 1) maximum shear force $(\mathrm{g} / \mathrm{g}$ sample) and 2) area under the curve ( $\left.\mathrm{g}^{*} \mathrm{~mm}\right)$ from $0 \mathrm{~g}$ force to maximum force. The remaining muscle from the fillets were pulverized with liquid nitrogen in a stainless steel, Waring Blender (Waring, New Hartford, CT, U.S.A.) and kept at $-25^{\circ} \mathrm{C}$ for $\mathrm{pH}$ and proximate composition analyses.

The $\mathrm{pH}$ measurements were performed in duplicate and expressed as the average. Five grams of powdered, raw sample were mixed with $25-\mathrm{mL}$ distilled water, and $\mathrm{pH}$ was measured using a combination electrode ( $\mathrm{pH} /$ ion analyzer 350; Corning Inc., NY, U.S.A.). Proximate composition of muscle samples was determined using AOAC (1990) approved methods. Crude fat was analyzed using the Soxhlet solvent extractor. Percent crude fat was calculated based on the difference before and after extraction with petroleum ether. Moisture was determined by the ovendrying method $\left(100^{\circ} \mathrm{C}\right.$ for $\left.18 \mathrm{~h}\right)$. Moisture loss was calculated as a percent of the raw sample weight. Ash content was determined by the dry ashing method. Two gram of powdered sample was placed in muffle furnace at $550^{\circ} \mathrm{C}$ overnight. Ash content was reported as a percent of the raw sample weight. Crude protein was determined using Kjeldahl Nitrogen Method. Percent nitrogen content was converted to crude protein content by using 6.25 as the conversion factor.

Hydroxylysyl pyridinoline (PYD) cross-links are key contributors to fillet firmness, and its concentration in fish muscle is very low (Hagen et al., 2007). Therefore, we determined alkalineinsoluble (a-i) hydroxyl proline in which Li et al. (2005) have shown that almost $100 \%$ of PYD cross-links could be recovered. Hydroxyproline is a measure of PYD cross-links and was 
determined following the method of $\mathrm{Li}$ et al. (2005). Sodium hydroxide $(0.2 \mathrm{M})$ was used to separate hydroxyproline into alkaline soluble and insoluble fractions. A 2- $\mu 1$ aliquot of hydrolysate was mixed with $200 \mu \mathrm{l}$ of water and dried in an Eppendorf tube using a centrifugal vacuum concentrator (Eppendorf $^{\circledR}$ 5301, Cole-Parmer, IL, U.S.A.). The pellet was resuspended in $200 \mu \mathrm{l}$ of $0.1 \mathrm{M}$ boric buffer, $\mathrm{pH} 11.4$, containing $11.2 \mu \mathrm{M}$ homoarginine as an internal standard. The fluorenylmethoxycarbonyl (FMOC) derivatized amino acids were separated using a ternary gradient described by Bank et al. (1996). The eluate was monitored for fluorescence at $\lambda_{\mathrm{ex}}=254$ $\mathrm{nm}$ and $\lambda_{\mathrm{em}}=630 \mathrm{~nm}$. The Varian Star Chromatograph Workstation software (version 6; Varian Inc., CA, U.S.A.) was used to identify and quantify homoarginine and hydroxyproline peaks. Sample hydroxyproline concentration was quantified based on the relative areas of the signals from sample and internal standard (Harris, 2007).

\subsection{Statistical analysis}

The experiment was conducted in the context of a $2 \times 6 \times 2$ randomized complete block design with a fixed block effect (family). Treatment effects included six age endpoints (July, September, November, December 2008; and January and March 2009) and two ploidy conditions (diploid, 2N; and triploid, 3N). Five fish were randomly assigned to each of four treatment combinations (two ploidy levels $\mathrm{x}$ two families) at each age endpoint. Therefore, each treatment combination was repeated five times on randomly selected fish. The first-order autoregressive process, AR(1), was used for modeling variance structure of live weight and SGR data obtained from tagged fish according to Wade and Quaas (1993). These fish were collected monthly from July to March, and only the 54 fish that were alive in March (27 2N and $273 \mathrm{~N}$ females) were used. Data from tagged and random fish were analyzed by analysis of variance (ANOVA) using the Mixed Model (MIXED) procedure of SAS ${ }^{\circledR}$ system for Windows, version 9.1 (SAS Institute Inc., 
2004). Relationships among independent variables were analyzed by Pearson product-moment correlation and linear regression analysis using CORR and REG procedures of SAS ${ }^{\circledR}$ system for Windows, version 9.1 (SAS Institute Inc., 2004), respectively. Significance was defined at $P<0.05$. 


\section{RESULTS}

\subsection{Growth and maturation}

Whole body weight of individual fish consistently increased throughout the 9-month

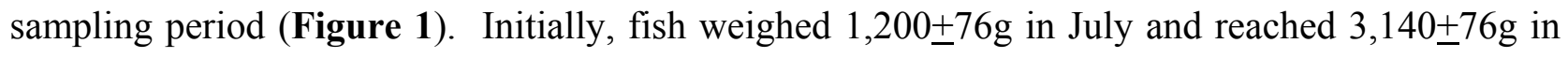
March 2009. From October to February, $2 \mathrm{~N}$ females were heavier than $3 \mathrm{~N}$ females; the difference ranged from 11 to $16 \%(P<0.0001)$. Regardless of ploidy, condition factor ranged from 1.65 to 2.39. Overall growth rate decreased for $2 \mathrm{~N}$ and $3 \mathrm{~N}$ females during the normal time of sexual maturation in diploids, although the decline was greater for $2 \mathrm{~N}$ females $(P<0.0001$; Figure 2). The $2 \mathrm{~N}$ females grew faster than the $3 \mathrm{~N}$ females from August through October; whereas, the reverse was true for February and March. The GSI of $2 \mathrm{~N}$ females increased 4.31 fold from September to November $(P<0.0001$; Figure 3) and then another 1.89 fold from November to January. Mean GSI was not calculated for $2 \mathrm{~N}$ females in March because five of ten females had ovulated. Percent viscera of whole body weight (WBW) for $2 \mathrm{~N}$ females dropped $21 \%$ by November; whereas, $3 \mathrm{~N}$ females showed an increase of $3.26 \%(P<0.0001$; Figure 4). The viscera of $3 \mathrm{~N}$ females was 1.42 times heavier than that of $2 \mathrm{~N}$ females. This difference reached 3.96 fold by March. On the average, $2 \mathrm{~N}$ females yielded $4.68 \%$ less separable muscle than $3 \mathrm{~N}$ fish $(P<0.0001$; Figure 5). Separable muscle was expressed as a percent of empty body weight (EBW) to remove variation associated with digestive tract content and gonad weight. Age endpoint*ploidy affected separable muscle as a percent of EBW $(P=0.0498$; Figure 6). Separable muscle of fertile $(2 \mathrm{~N})$ and sterile $(3 \mathrm{~N})$ females was equal through the first five months (55.87$57.03 \% ; P>0.05$ ); in March, 3N females had 1.04-fold higher muscle yield than $2 \mathrm{~N}$ females. Changes in percent separable muscle seemed to resemble those of specific growth rate; however, 
there was no correlation between these two variables $(P=0.086)$. Age endpoint*ploidy affected abdominal wall thickness $(P=0.0345$; Figure 7) that was at a minimum of $0.99 \mathrm{~cm}$ in July and increased to the maximum in March when $3 \mathrm{~N}$ abdominal wall thickness was higher than that of $2 \mathrm{~N}$ females (1.48 v. $1.31 \mathrm{~cm} ; P<0.05)$; mean separation between these two groups began in January.

\subsection{Chemical composition}

Transient, but significant changes in muscle fat content occurred in $2 \mathrm{~N}$ females, including an $18 \%$ decrease in fillet fat content between September and November; lowest values were observed in March $(P<0.0001$; Figure 8). Accordingly, fillet moisture content of $2 \mathrm{~N}$ females increased by $1.86 \%$ between September and November $(P>0.05)$ and highest values were observed in March $(P<0.05$; Figure 8). Inverse and greater changes in fat and moisture content were observed for $3 \mathrm{~N}$ fish (Figure 8). There was not age* ploidy effect on muscle protein content $(P>0.05)$. Averaged across ploidy, fillet protein and ash content ranged from 20.37 to $23.38 \%$ and 1.29 to $1.47 \%$, respectively. Fillet fat content correlated with percent viscera of EBW (data not shown; $\mathrm{r}=0.44 ; P<0.0001)$ and with abdominal wall thickness $(\mathrm{r}=0.50 ; P<0.0001)$. Averaged across ploidy, visceral fat content decreased from 94.94\% in July to $77.83 \%$ in September 2008. In March, crude fat content of this adipose tissue increased for both ploidies; however, crude fat of $2 \mathrm{~N}$ females were lower than that of $3 \mathrm{~N}$ females $(86.05$ v. $95.05 \%$, respectively; $P=0.0428)$.

Egg growth and development (age*ploidy effect), or ploidy, did not affect muscle $\mathrm{pH}, \mathrm{L}^{*}$ or $b^{*}$ values $(P>0.05)$. Muscle $\mathrm{pH}$ ranged from 6.4 to $6.7 ; \mathrm{L}^{*}$ value ranged from 44.16 to 48.14 , and $\mathrm{b}^{*}$ value ranged from 2.75 to 5.72 throughout the sampling period. Muscle $\mathrm{a}^{*}$ value increased for $2 \mathrm{~N}$ females during maturation $(P<0.0001$; Figure 9), with the muscle surface of $2 \mathrm{~N}$ females having higher $\mathrm{a}^{*}$ values (green-magenta axis) from December to March, than those of $3 \mathrm{~N}$ females 
which did not change during the normal time of sexual maturation in diploids. Muscle $\mathrm{pH}$ did not correlate with instrumental texture or muscle color $(P>0.05)$. Muscle fat did not correlate with muscle color $(P>0.05)$. Regardless of ploidy, muscle content of alkaline-insoluble hydroxyproline (a-i HYP) ranged from 11.25 to $23.35 \mu \mathrm{mole} / \mathrm{g}$ from July to January (Figure 10). However, from January to March, the concentration of muscle, a-i HYP of $2 \mathrm{~N}$ females increased by $336 \%$, and it was two-fold higher than that of $3 \mathrm{~N}$ females (age*ploidy effect; $P=0.0279$ ).

\subsection{Texture}

Age affected shear force $(P<0.0001$, Figure 11) and energy of shear $(P<0.0001$, Figure 12). Regardless of ploidy, raw fillets were softer from September through January (average shear force $=288.77 \mathrm{~g} / \mathrm{g}$ ) than raw fillets in July $(475.15 \mathrm{~g} / \mathrm{g})$ and March $(366.79 \mathrm{~g} / \mathrm{g})$. From July to January and regardless of ploidy, energy of shear of both ploidies ranged from $1.65 \mathrm{E}+05$ to 2.32E+05 g*mm; maximum energy $(3.45 \mathrm{E}+05 \mathrm{~g} * \mathrm{~mm})$ was observed in March. We also observed an effect of ploidy on energy of shear $(P=0.0171) ; 2 \mathrm{~N}$ female muscles required more energy to shear through than those of $3 \mathrm{~N}$ females $\left(2.36 \mathrm{E}+05\right.$ v. $\left.2.09 \mathrm{E}+05 \mathrm{~g}^{*} \mathrm{~mm}\right)$. In addition, muscle fat content negatively correlated with maximum force $(r=-0.35, P=0.0005)$, explaining $12 \%$ of the total variation. Shear force moderately correlated with specific growth rate $(\mathrm{r}=-0.34, P=0.0006)$. Similarly, energy of shear correlated with specific growth rate $(\mathrm{r}=-0.45, P<0.0001)$. Concentration of a-i HYP was positively correlated with energy of shear $(\mathrm{r}=0.41, P=0.0007)$, explaining $17 \%$ of the total variation in this texture response. 


\section{DISCUSSION}

\subsection{Growth and maturation}

Egg growth and development occurred in fertile, $2 \mathrm{~N}$ females, reaching a peak in March when about half of the females ovulated; whereas, the sterile $3 \mathrm{~N}$ females showed little gonadal development, indicated by low GSI, throughout the study. At the end of the spawning season in March, there were no differences in size measures between $2 \mathrm{~N}$ and $3 \mathrm{~N}$ fish including body weight and condition factor, but there were differences in yield, composition, and quality traits. The impact of gonadal development on metabolism and energy partitioning was readily apparent as increases in muscle fat and visceral weights in $3 \mathrm{~N}$ fish compared with no change in muscle fat and reductions in visceral weights in $2 \mathrm{~N}$ fish, and the $2 \mathrm{~N}$ fish grew significantly faster than $3 \mathrm{~N}$ fish early and then more slowly closer to spawning. Nevertheless, SGR was always positive and visceral fat was always present. Washburn and others (1990) reported viscero-somatic indices (VSI) at $2 \%$ at the beginning and the end of a nine-month sampling period for 2-year-old female rainbow trout. In the present study, however, visceral weight, which did not include the gonad and gall bladder, never dropped below $4 \%$, and fillet protein content was not altered in the $2 \mathrm{~N}$ fish supporting that little catabolic activity took place beyond visceral lipid mobilization. Although there was no difference in $\mathrm{CF}$ between $2 \mathrm{~N}$ and $3 \mathrm{~N}$ fish, it is clear that condition was maintained; there was a strong correlation between gonad weight, gained by $2 \mathrm{~N}$ compared to $3 \mathrm{~N}$ fish, and gains in visceral weights by $3 \mathrm{~N}$ compared with $2 \mathrm{~N}$ fish $\left(\mathrm{r}=-0.73 ; \mathrm{R}^{2}=0.53 ; P<0.0001\right.$; not including data in March). One caveat in comparing $2 \mathrm{~N}$ to $3 \mathrm{~N}$ fish in the current study is that, although fish were fed to satiation, it is likely that feed intake was greater for the $3 \mathrm{~N}$ fish than $2 \mathrm{~N}$ fish since maturing rainbow trout commonly reduce feed intake (Washburn et al., 1990). 
The difference in percent separable muscle on an EBW basis between $2 \mathrm{~N}$ and $3 \mathrm{~N}$ was not evident until the final sampling period. However, abdominal wall flap thickness of both ploidies increased over the period of gonad development and the thicker abdominal wall in $3 \mathrm{~N}$ than $2 \mathrm{~N}$ females was evident early in January. The difference in separable muscle with ploidy in the current study was much less than in previous studies conducted with fish on a low nutritional plane such as in Salem and others (2006a) where there was an $11 \%$ reduction in separable muscle in maturing $2 \mathrm{~N}$ compared with $3 \mathrm{~N}$ fish. Data from the current study suggest that fillet mass can be maintained during gonad development if fish are maintained on a high nutritional plane. In addition, protein was also spared. There was no difference in protein content of fillets from $2 \mathrm{~N}$ and $3 \mathrm{~N}$ females or over the duration of the study. Salem and others (2006a) observed an $11 \%$ reduction in protein content of $2 \mathrm{~N}$ fillets during spawning season in early October. Washburn and others (1990) also observed growth cessation, beginning four months prior to spawning. Muscle growth of $3 \mathrm{~N}$ females could have been maintained on a more restricted diet since muscle fat and $\%$ visceral weight increased considerably over the course of the study.

Our data suggested that gonad development was primarily supported by mobilization of visceral fat. There was a strong correlation between change in GSI and visceral weight in the $2 \mathrm{~N}$ fish, similar to what was reported in previous studies of rainbow trout (Takashima et al., 1971; Washburn et al., 1990). In November when visceral fat was first reduced in $2 \mathrm{~N}$ females, there was also a reduction of fat in muscle; however, muscle fat content remained stable thereafter suggesting muscle fat is mobilized early in gonadal growth, and depletion of visceral fat is not requisite for muscle fat mobilization. In farmed Atlantic salmon, fillet fat decreased concurrently with visceral weight also supporting that muscle fat is mobilized well before visceral fat deposits are depleted (Aksnes et al., 1986). 


\subsection{Chemical composition}

Lipid content of somatic and visceral tissues was high in maturing salmon in July and decreased to a minimum after spawning in November, whereas protein in these tissues was relatively stable (Jonsson et al., 1997). An increase in moisture content is an indication of a more advanced state of maturity; moisture content inversely relates to lipid and protein content as these components are consumed for energy through spawning (Gilhousen, 1980; Hendry and Berg, 1999). We used a high plane of nutrition with fertile $(2 \mathrm{~N})$ and sterile $(3 \mathrm{~N})$ females to define impact of sexual maturation on muscle production and composition, exclusive of the effect of dietary limitations. Given the plane of nutrition and therefore level of lipid stored in intramuscular and visceral adipose tissue, nutritional stress imposed by egg growth and development was not sufficient to cause protein catabolism. An insignificant age*ploidy effect on muscle protein content $(P>0.05)$ and the equal percent separable muscle of empty body weight of $2 \mathrm{~N}$ and $3 \mathrm{~N}$ female between November to January suggested that $2 \mathrm{~N}$ females might have good nutritional background. As previously reported by Kiessling et al. (1995), rainbow trout preserved the fast twitch isoform of myosin heavy chain from white muscle, in spite of a metabolic alteration during spawning. In wild rainbow trout, prevention of catabolic breakdown of muscle protein during long periods of fasting preserves contractile capacity of the muscle, which is necessary for establishing a territory, reproduction, and survival until the next reproduction cycle (Suarez and Mommsen, 1987). In farmed rainbow trout, no effect of ploidy was found with regard to the protein content (Poontawee et al., 2007). In wild chum salmon, while declines in lipid of somatic tissue were significant, declines in protein were not (McVeigh et al., 2007).

The number and diameter of muscle fibers affect texture, and this influence varies between sexes and seasons (Hurling et al., 1996; Johnston et al., 2000b; Hagen et al., 2007). Suresh and 
Sheehan (1998) indicated that redirection of energy from somatic growth to egg growth and development does not necessarily retard muscle fiber growth processes. However, Benfey (1999) found that diploid muscle fibers had smaller cross-sectional area and higher fiber density than those of triploid animals. Instead of ploidy, nutritional restriction significantly affected fillet texture in Atlantic salmon; 30-day starvation gave higher shear force than fresh fillets from 7-daystarved and non-starved animals (Sigurgisladottir et al., 2001). Additionally, a weak correlation between shear force and fiber density has been reported ( $\mathrm{r}=0.22, P<0.05$; Bjørnevik, 2004). Albeit, differences in survival and growth of diploids and triploids at different stages of growth are not consistent (Piferrer et al., 2009). In the present study, there was no difference in fillet firmness between the two ploidy levels at any age. Therefore, we could not relate changes in fillet texture to changes in morphometric traits associated with ploidy.

As discussed by Dunajski (1979), many studies found that muscle $\mathrm{pH}$ is the most important single factor determining fillet texture. High $\mathrm{pH}$ (6.96) and high water content after starvation or spawning was associated with a soft fillet texture (Love, 1972). Nevertheless, Love et al. (1974) found that changes in $\mathrm{pH}$ could be related to those of muscle fiber size and tenderness only in well nourished females at certain fishing seasons. In the present study, egg growth and development did not affect muscle $\mathrm{pH}$, and $\mathrm{pH}$ did not correlate with fillet texture and muscle color $(P>0.05)$. In Atlantic salmon, lightness varied with ploidy while redness was related to texture (Bjørnevik et al., 2004). The lighter and less red muscle of diploid rainbow trout could be attributed to gonadal development, and female diploids transfer more red pigment from the diet to the gonads (Poontawee et al., 2007). The present study found that egg growth and development may influence the mobilization of red pigment in muscle which occurred between November and 
March; however, we did not have enough information to relate this event to the differences in muscle fiber structure.

\subsection{Texture}

Shear force data depicts two phases of change including 1) fillet softening during egg growth and development from November to January and 2) fillet toughening at spawning in March. Changes in fillet texture in the first period could relate to growth rate and muscle fat content; whereas the second phase could relate to reduced collagen solubility.

Softer fillets between November and January may be associated with growth rate ( Hagen et al., 2007; Folkestad et al., 2008). Declining SGR of $2 \mathrm{~N}$ females suggested a decrease in somatic growth. The period of transition (November-January), which was equal to those of $3 \mathrm{~N}$, suggested that feed intake was sufficient to offset requirements of gonadal development and thus muscle catabolism. Transition in growth rate of both ploidy levels from November to January might explain why texture was not affected by ploidy $(P>0.05)$. In starved brown trout, growth rate increased during re-feeding because of compensatory growth, and the energy reserve was completely restored in the visceral tissue (Bugeon et al., 2004). The change in muscle metabolism in response to alterations in feeding status is a rather slow process in trout, and differences in feeding status alone cannot explain observed differences between spawning and non-spawning fish (Kiessling et al., 1995). In addition, muscle fiber growth in fish is under a combination of genetic and environmental controls (Kiessling et al., 2006).

Striated muscle in fish is made up of three major compartments - contractile proteins, lipids, and connective tissue; all components affect product quality (Kiessling et al., 2006). Sequential use of endogenous tissue stores to supply energy required for maintenance of 
physiological events during a long-term fasting period significantly impact structure and composition of muscle and connective tissue (Bugeon et al., 2004 and references therein). In the present study, muscle fat was a key factor influencing fillet texture and other quality attributes. Although genetic predisposition was not a variable of interest, we recognized potential impact of family on fillet texture and treated this variable as a fixed-block factor in mixed model analysis to adjust for differences in response due to family. As expected, the primary difference was observed in muscle fat content between family $70(10.8 \%)$ and family $71(6.24 \% ; P=0.0001)$. Increased fat content in rainbow trout fillets was associated with hypertrophic growth of muscle fibers and adipocytes (Fauconneau et al., 1997). In terrestrial animals, muscle fat content at a level of 3\% to 7.3\% contributes positively to sensory texture (Smith et al., 2004). At increasing fat levels, adipose cells or marbling imbedded in the perimyseal connective tissue can undermine mechanical strength of connective tissue (Miller, 2004). In fish, Dunajski (1979) proposed that immobilized free water and liquid neutral lipids are key components that tend to dilute the structural elements of muscle and decrease the overall mechanical strength of meat. Muscle containing more fat tends to be tenderer, while in lean species, tenderness increases with water content. Scanning electron microscopy showed that fast muscle fibers of salmon are covered with a continuous sheet of connective tissue and lipid droplets, particularly in the region of the myosepta ( $\mathrm{Li}$ et al., 2005). Therefore, it is possible that lipid inclusion influences the connective tissue matrix at the myosepta of fish fillets. In the present study, muscle fat content was moderately correlated with shear force $\left(\mathrm{r}=-0.35, \mathrm{R}^{2}=0.12\right)$. At the same time, correlation analysis suggested that insoluble collagen contributed to muscle extensibility or amount of energy required to shear through the sample. Skin collagen of starved brown trout formed more, high-molecular-weight collagen and developed greater thermal stability, which remained significant after the re-feeding period. Nonetheless, 
changes in connective tissue characteristics were inconsistent with increased mechanical resistance of raw flesh (Bugeon et al., 2004). Collagen content as well as degree of chemical cross-links within the protein increase with age and play a role in maintaining cohesiveness of raw fillets (Sato et al., 1986a,b).

Muscle fat is associated with connective tissue, and at a certain level, it could offset the role of connective tissue in fillet texture development. In highly marbled meat, fat dilutes muscle fibers and connective tissue (Purchas, 2004). Moreover and as described previously, muscle fat may interfere with connective tissue by its relative amount and spatial arrangement in muscle structure. Moreover, lipid stored in perimyseal adipose cells and released during shear provided lubrication between muscle fibers (Miller, 2004). Therefore, muscle fibers that are bathed in higher amounts of lipid can slide more easily across each other and generate less resistance during shear. Therefore, muscle fat, at the level observed in the present study between November and January (7-12\%), could be a key contributor to soft fillets. An alternative is to compare the contribution of muscle fat to the stability of the myosin/actomyosin complex and to liquid-holding capacity of muscle between fatty fish such as salmon and lean fish such as cod (Ofstad et al., 1996a,b).

In salmon, the alkaline-insoluble collagen fraction, which is enriched with reducible and mature collagen cross-links, contributes to fillet firmness (Li et al., 2005). Increased collagen insolubility could be translated into an increase in collagen cross-links that strengthen the perimyseal connective tissue network. This connective tissue network wraps around muscle fiber bundles and contributes to their resistance to shear. Hagen et al. (2007) found that hydroxylysyl pyridinoline cross-links are more concentrated in the fish muscle with increased water content, explaining $61 \%$ of the total variation. In March, a significant increase in a-i HYP of $2 \mathrm{~N}$ muscle 
concurred with a substantial increase in muscle moisture content and a decrease in fat content, suggesting that the role of collagen cross-links in fillet texture might be associated with amount of water and fat in muscle. In $3 \mathrm{~N}$ females, a-i HYP increased as moisture decreased. Muscle a-i HYP concentration, however, did not correlate with moisture content $(P=0.1260)$. Li et al. (2007) found that growth rate influences cross-link formation; growth rate explained $6.5 \%$ of the total variation in collagen cross-linking in juvenile salmon; however, it was sufficient to produce a $15.6 \%$ reduction in fillet firmness. In the present study growth rate (SGR) explained $11 \%$ of the total variation in a-i HYP of raw fillets, and it contributed to a $11 \%$ reduction in shear force and a $21 \%$ increase in energy of shear for raw fillets. It is possible that both connective tissue and muscle fiber contribute to softening of raw texture (Montero and Borderias, 1990c). In terrestrial species, muscle cathepsins may act on collagen (Dingle et al., 1971; Barret, 1974; Etherington 1976, 1977). However, future research is needed to determine whether cathepsins act on collagen in fish, and whether they are triggered by egg growth and development. 


\section{CONCLUSION}

Egg growth and development did not cause muscle atrophy of fertile females due to body composition indicative of a high plane of nutrition. Muscle fat interacted with muscle fiber and connective tissue characteristics in the development of fillet texture. Increased collagen insolubility at the time of spawning in March resulted in firmer fillets. 


\section{REFERENCES}

Aksnes, A., Gjerde, B., Roald, S.O., 1986. Biological, chemical and organoleptic changes during sexual maturation of farmed Atlantic salmon, Salmo salar. Aquaculture 53, 7-20.

Allen S.K. 1983. Flow cytometery: Assaying experimental polyploidy fish and shellfish. Aquaculture. 33, 317-328.

AOAC. 1990. Official Methods of Analysis. 15th ed. Washington, DC: Association of Official Analytical Chemists.

Bank, R.A., Jansen, E.J., Beekman, B., te Koppele, J.M., 1996. Amino acid analysis by reversephase high-performance liquid chromatography: improved derivatization and detection conditions with 9-fluorenylmethyl chloroformate. Analytical biochemistry. 240, 167-176.

Barret, A. J., 1974. The enzymic degradation of cartilage matrix, in: Burleigh, M.C., Poole, A.R. (Eds.), Dynamics of Connective Tissue Macromolecules. North-Holland Publishers, Amsterdam, pp. 189.

Benfey, T.J., 1999. The physiology and behavior of triploid fishes. Reviews in Fisheries Science 7 , 39-67.

Bjørnevik, M., Espe, M., Beattie, C., Nortvedt, R., Kiessling, A., 2004. Temporal variation in muscle fiber area, gaping, texture, colour and collagen in triploid and diploid Atlantic salmon (Salmo salar L.). J. Sci. Food Agric. 84, 530-540.

Bugeon, J., Lefévre, F., Fauconneau, B., 2004. Correlated changes in skeletal muscle connective tissue and flesh texture during starvation and re-feeding in brown trout (Salmo trutta) reared in seawater. Journal of the Science of Food and Agriculture 84, 1433-1441.

Bugeon, J., Lefévre, F., Cardinal, M., Uyanik, A., Davenel, A., Haffray, P., 2010. Flesh quality in large rainbow trout with higher or low fillet yield. Journal of Muscle Foods 21, 702-721.

Cousin-Gerber, M., Georges, B., Boisseau, C., 1989. Effect of methyltestosterone on sex differentiation and gonad morphogenesis in rainbow trout Oncorhynchus mykiss. Aquat. Living Resour. 2, 225-230.

Dingle, J. T., Barret, A.J., Weston, P.D., 1971. Cathepsin D: characterization of immunoinhibition and the confirmation $\mathrm{f}$ a role in cartilage breakdown. Biochem. J. 123, 1-15.

Dunajski, E. (1979). "Texture of fish muscle." Journal of Texture Studies 10: 301-318. 
Etherington, D.J., 1976. Bovine spleen cathepsin $\mathrm{B}_{1}$ and collagenolytic cathepsin: a comparative study of the properties of the two enzymes in the degradation of native collagen. Biochem. J. 153, 199-210.

Etherington, D. J., 1977. The dissolution of insoluble bovine collagens by cathepsin B1, collagenolytic cathepsin and pepsin: the influence of collagen type, age, and chemical purity on susceptibility. Conn. Tissue Res. 5, 135-137.

Fauconneau, B., Andre, S., Chmaitilly, J., Le Bail, P.-Y., Krieg, F., Kaushik, S.-J., 1997. Control of skeletal muscle fibers and adipose cell size in the flesh of rainbow trout. J. Fish Biol. 50, 296-314.

Foegeding, E.A., Lanier, T.C., Hultin, H.O., 1996. Characteristics of edible muscle tissues, in: Fennema, O.R. (Ed), Food Chemistry. third ed. Marcel Dekker Inc., New York, pp. 879942.

Folkestad, A., Rørvik, K.-A., Kolstad, K., M Ørk Ør, T., 2008. Growth rates of individual farmed Atlantic salmon Salmo salar L. influence the texture of raw and smoked fillets. Aquac. Res. 39, 329-332.

Foss, A., Imsland, A.K., Vikingstad, E., Stefansson, S.O., Norberg, B., Pedersen, S., Sandvik, T., Roth, B., 2009. Compensatory growth in Atlantic halibut: Effect of starvation and subsequent feeding on growth, maturation, feed utilization and flesh quality. Aquaculture 290, 304-310.

Gilhousen, P., 1980. Energy sources and expenditures in Fraser River sockeye salmon during their spawning migration. International Pacific Salmon Fisheries Commission Bulletin 22, 1-51.

Gomez-Guillen, M.C., Montero, P., Hurtado, O., Borderias, A.J., 2000. Biological characteristics affect the quality of farmed Atlantic salmon and smoked muscle. J. Food Sci. 65, 53-60.

Gutsell, J.S., 1940. The feeding of trout brood stock: the diet of rainbow trout in relation to quantity, quality, and cost of eggs. The Progressive Fish-culturist 7, 19-28.

Hagen O., Solberg, C., Sirnes, E., Johnston I.A., 2007. Biochemical and structural factors contributing to seasonal variation in the texture of farmed Atlantic halibut (Hippoglossus hippoglossus L.) flesh. J. Agric. Food Chem. 55, 5803-5808.

Harris, D.C., 2007. Quantitative Chemical Analysis. W.H. Freeman and Company, New York.

Hershberger, W.K., Hostuttler, M.A. 2007. Protocols for more effective induction of tetraploid rainbow trout. North American Journal of Aquaculture. 69, 367-372.

Hendry, A. P., Berg, O.K., 1999. Secondary sexual characters, energy use, senescence, and the cost of reproduction in sockeye salmon. Canadian Journal of Zoology 77, 1663-1675. 
Hernández-Herrero, M.M., Duflos, G., Malle, P., Bouquelet, S., 2003. Collagenase and protein activity as related to spoilage of iced cod (Gadus morhua). Food Research International 36, 141-147.

Hurling, R., Rodell, J.B., Hunt, H.D., 1996. Fibre diameter and fish texture. J. Tex. Stud. 27, 679685.

Hyldig, G., Nielsen, D. 2007. Texture of fish, fish products, and shellfish. In: Nollet, L.M.L., editor. Handbook of meat, poultry and seafood quality. Ames, IA: Blackwell Publishing. p 549-561.

Jonsson, N., Jonsson, B., Hansen, L.P., 1997. Changes in proximate composition and estimates of energetic costs during upstream migration and spawning in Atlantic salmon Salmo salar. Journal of Animal Ecology 66, 425-436.

Johnston, I.A., 1999. Muscle development and growth: potential implications for flesh quality in fish. Aquaculture 177, 99-115.

Johnston, I.A., Alderson, R., Sandham, C., Dingwall, A., Mitchell, D., Selkirk, C., Nickell, D., Baker, R., Robertson, B., Whyte, D., Springate, J., 2000. Muscle fiber density in relation to colour and texture of smoked Atlantic salmon (Salmo salar L.). Aquaculture 189, 335-349.

Kubota, S., Kinoshita, M., Yokohama, Y., Toyohara, H., Sakaguchi, M., 2000. Induction of gelatinolytic activities in ayu muscle at the spawning stage. Fish Sci. 66, 574-578.

Kiessling, A., Larsson, L., Kiessling, K.-H., Lutes, P.B., Storebakken, T., Hung, S.S.S., 1995. Spawning induces a shift in energy metabolism from glucose to lipid in rainbow trout white muscle. Fish Physiology and Biochemistry 14(6), 439-448.

Kiessling, A., Ruohonen, K., Bjørnevik, M., 2006. Muscle fiber growth and quality in fish. Arch. Tierz., Dummerstorf 49 Special issue, 137-146.

Li, X., Bickerdike, R., Lindsay, E., Campbell, P., Nickell, D., Dingwall, A., Johnston, I.A., 2005. Hydroxylysyl pyridinoline cross-link concentration affects the textural properties of fresh and smoked Atlantic salmon (Salmo salar L.) flesh. J. Agric. Food Chem. 53, 6844-6850.

Li, X., Bickerdike, R., Nickell, D., Campbell, P., Dingwall, A., Johnston, I.A., 2007. Investigations on the effects of growth rate and dietary vitamin $\mathrm{C}$ on skeletal muscle collagen and hydroxylysyl pyridinoline cross-link concentration in farmed Atlantic salmon (Salmo salar). J. Agric. Food Chem. 55, 510-515.

Love, R.M., Muslemuddin, M., 1972. Protein denaturation in frozen fish, XII. The pH effect and cell fragility determinations. J. Sci. Food Agric. 23, 1229-1238.

Love, R. M., Robertson, J., Smith, G.L., Whittle, K.J., 1974. The texture of cod muscle. J. Tex. Stud. 5, 201-212. 
Love, R. M., 1988. The food fishes: their intrinsic variation and practical implications. Farrand Press, London.

McVeigh, B. R., Healey, M.C., Wolfe, F., 2007. Energy expenditures during spawning by chum salmon Oncorhynchus keta (Walbaum) in British Columbis. Journal of Fish Biology 71, 1696-1713.

Miller, R.K., 2004. Chemical and physical characteristics of meat / Palatability, in: Jensen, W.K. (Ed.), Encyclopedia of meat sciences. Elsevier Ltd., Oxford, pp. 256-265.

Montero, P., Borderías, J., 1990a. Behavior of myofibrillar proteins and collagen in hake (Merluccius merluccius L.) muscle during frozen storage and its effect on texture Z. Lebensm. Unters. Forsch. 190, 112-117.

Montero, P., Borderías, J., 1990b. Effect of rigor mortis and ageing on collagen in trout (Salmo irideus) muscle. J. Sci. Food Agric 52, 141-146.

Montero, P., Borderías, J., 1990c. Influence of age on muscle connective tissue in trout (Salmo irideus). J. Sci. Food Agric. 51, 261-269.

Ofstad, R., Egelandsdal, B., Kidman, S., Myklebust, R., Olsen, R.L., Hermansson, A.-M., 1996a. Liquid loss as affected by post-mortem ultrastructural changes in fish muscle; cod (Gadus morhua L.) and salmon (Salmo salar). J. Sci. Food Agric 71, 301-312.

Ofstad, R., Kidman, S., Hermansson, A.-M., 1996b. Ultramicroscopical Structures and Liquid Loss in Heated Cod ( Gadus morhua L.) and Salmon ( Salmo salar) Muscle. Journal of the Science of Food and Agriculture 72(3), 337-347.

Palti, Y., Li, J.J., Throrhaard, G.H., 1997. Improved efficiency of heat and pressure shocks for producing gynogenetic rainbow trout. The progressive Fish-Culturist. 59, 1-13.

Piferrer, F., Beaumont, A., Falguière, J.-C., Flajšhans, M., Haffray, P., Colombo, L., 2009. Polyploid fish and shellfish: production, biology and applications to aquaculture for performance improvement and genetic containment. Aquaculture 293, 125-156.

Poontawee, K., Werner, C., Mueller-Belecke, A., Hoerstgen-Schwark, G., Wicke, M., 2007. Flesh qualities and muscle fiber characteristics in triploid and diploid rainbow trout. J. Appl. Ichthyol 23, 273-275.

Purchas, R.W., 2004. Tenderness Measurement, in: Jensen, W.K. (Ed.), Encyclopedia of meat sciences. Elsevier Ltd., Oxford, pp. 1370-1376. 
Salem, M., Kenney, P.B., Rexroad, C.E., $3^{\text {rd }}$, Yao J., 2006a. Molecular characterization of muscle atrophy and proteolysis associated with spawning in rainbow trout. Comp. Biochem. Physiol D - Genomic \& Proteomics, 1, 227-237.

Salem, M., Kenney, P.B., Rexroad, C.E., $3^{\text {rd }}$, Yao, J., 2006b. Microarray gene expression analysis in atrophying rainbow trout muscle: a unique nonmammalian muscle degradation model. Physiol Genomics 28, 33-45.

SAS Institute Inc. 2004. SAS/STAT ${ }^{\circledR} 9.1$ user's guide, first ed. SAS Publishing, NC.

Sato, K., Yoshinaka, R., Sato, M., and Shimizu, Y., 1986a. Collagen content in the muscle of fishes in association with their swimming movement and meat texture. Bulletin of the Japanese Society of Scientific Fisheries 52(9), 1595-1600.

Sato, K., Yoshinaka, R., Sato, M., Ikeda, S., 1986b. A simplified method for determining collagen in fish. Nippon Suisan Gakkaishi 52, 889-893.

Savell J.W., Cross, H.R., 1988. The role of fat in the palatability of beef, pork, and lamb, in: Committee on technological options to improve the nutritional attributes of animal products (Ed), Designing foods: animal product options in the Marketplace. National Academy Press, Washington, DC, pp. 345-356.

Shigemura, Y., Ando, M., Tsukamasa, Y., Makinodan, Y., Kawai, T., 2003. Correlation of type V collagen content with post-mortem softening of fish meat during chilled storage. Fisheries Science 69, 842-848.

Sigurgisladottir, S., Sigurdardottir, M.S., Ingvarsdottir, H., Torrissen O.J., Hafsteinsson, H., 2001. Microstructure and texture of fresh and smoked Atlantic salmon, Salmo salar L., fillets from fish reared and slaughtered under different conditions. Aquac. Res. 32, 1-10.

Suarez, R. K., Mommsen, T.P., 1987. Gluconeogenesis in teleost fishes. Can J Zool 65, 18691882.

Suresh, A.V., Sheehan, R.J., 1998. Muscle fiber growth dynamics in diploid and triploid rainbow trout. J. Fish Biol. 52, 570-587.

Takashima, F., Hibiya, T., Watanabe, T., Hara, T., 1971. Endocrinological studies on lipid metabolism in rainbow trout - I. Differences in lipid content of plasma, liver and visceral adipose tissue between sexually immature and mature females. Bulletin of the Japanese Society of Scientific Fisheries 37(4), 307-311.

Toyohara, H., Ito, K., Ando, M., Kinoshita, M., Shimizu, Y., Sakaguchi, M., 1991. Effect of maturation on activities of various proteases and protease inhibitors in the muscle of ayu (Plecoglossus altivelis). Comp. Biochem. Physiol. B 99, 419-424. 
Touhata, K., Tanaka, M., Toyohara, H., Tanaka, H., Sakaguchi, M., 2000. Seasonal change in collagen content of red seabream muscle. Fish Sci. 66, 553-557.

Wade, K.M., Quaas, R.L., 1993. Genetics and breeding: solutions to a system of equations involving a first-order autoregressive process. J. Dairy Sci. 76, 3026-3032.

Wang, P.A., Martinez, I., Olsen R.L., 2009. Myosin heavy chain degradation during post mortem storage of Atlantic cod (Gadus morhua L.). Food Chemistry 115, 1228-1233.

Washburn, B. S., Erye, D.J., Hung, S.S.O., Doroshov, S.I., Conte, F.S., 1990. Dietary effects on tissue composition, oogenesis and the reproductive performance of female rainbow trout (Oncorhynchus mykiss) Aquaculture 90, 179-195.

Williams, J. E., 2000. The Coefficient of Condition of Fish. Chapter 13, in: Schneider, J.C. (Ed.), Manual of Fisheries Survey Methods II: with periodic updates. Michigan Department of Natural Resources, Fisheries Special Report 25. Ann Arbor.

Williams, I. V., Brett, J.R., Bell, G.R., Traxler, G.S., Bagshaw, J., McBride, J.R., Fagerlund, U.H.M., Dye, H.M., Sumpter, J.P., Donaldson, E.M., Bilinski, E., Tsuyuki, H., Peters, M.D., Choromanski, E.M., Cheng, J.H.Y., Coleridge, W.L., 1986. The 1983 early run Fraser and Thompson River pink salmon; morphology, energetics and fish health. Bulletin of the International Pacific Salmon Fisheries Commission 23, 1-55.

Yamashita, M., Konagaya, S., 1990. High activities of cathepsin-B, cathepsin-D, cathepsin-H and cathepsin- $\mathrm{L}$ in the white muscle of chum salmon in spawning migration. Comp. Biochem. Physiol. B 95, 149-152. 


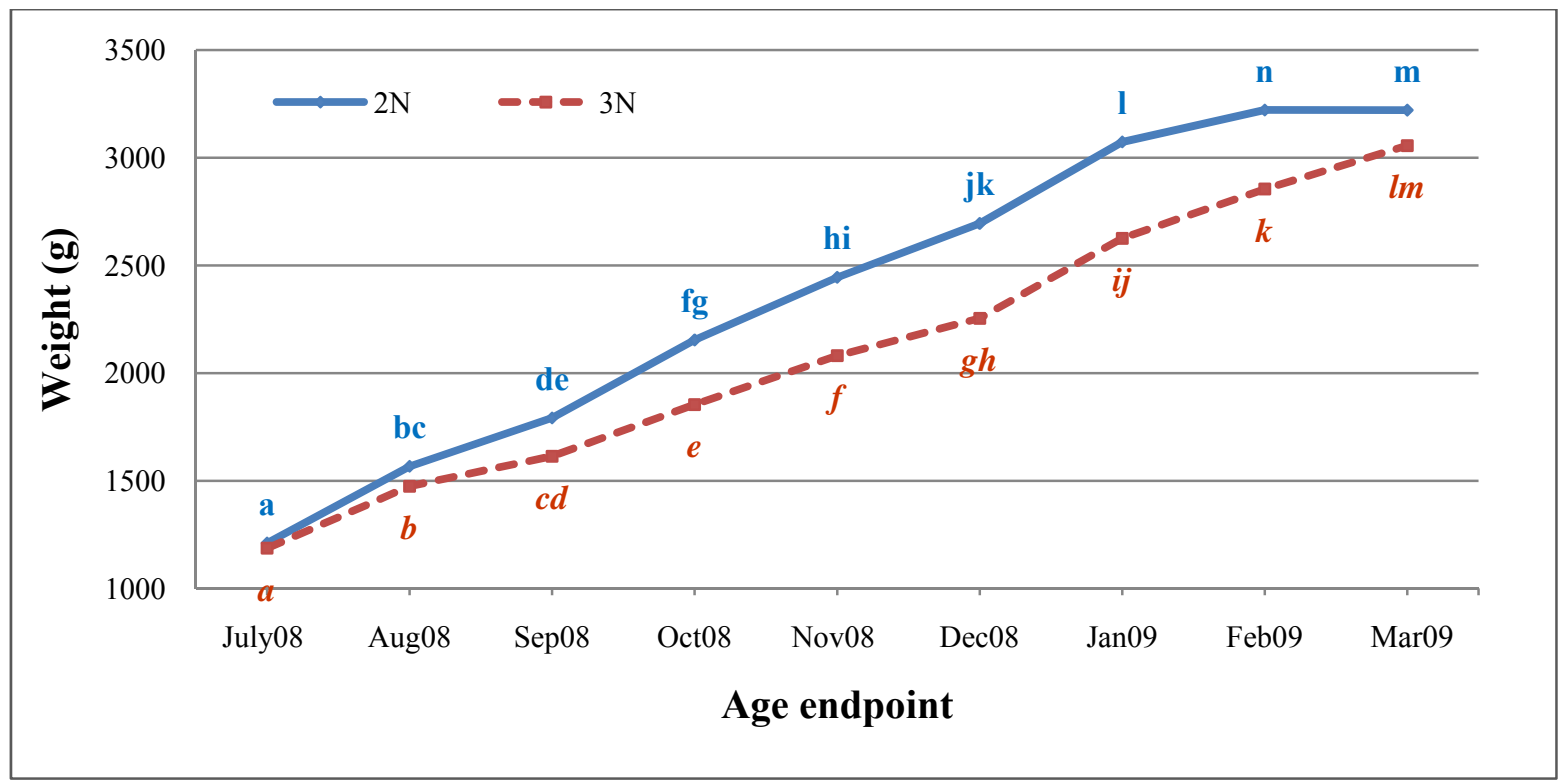

Figure 1 Whole body weight (g) of individually tagged fish as a function of age endpoint. Values are least square means. ${ }^{\mathrm{a}-\mathrm{m}}$ Different letters are different $(P<0.05) . \quad \mathrm{N}=54 . \quad \mathrm{SEM}=82(2 \mathrm{~N})$ and 70 $(3 \mathrm{~N})$. 


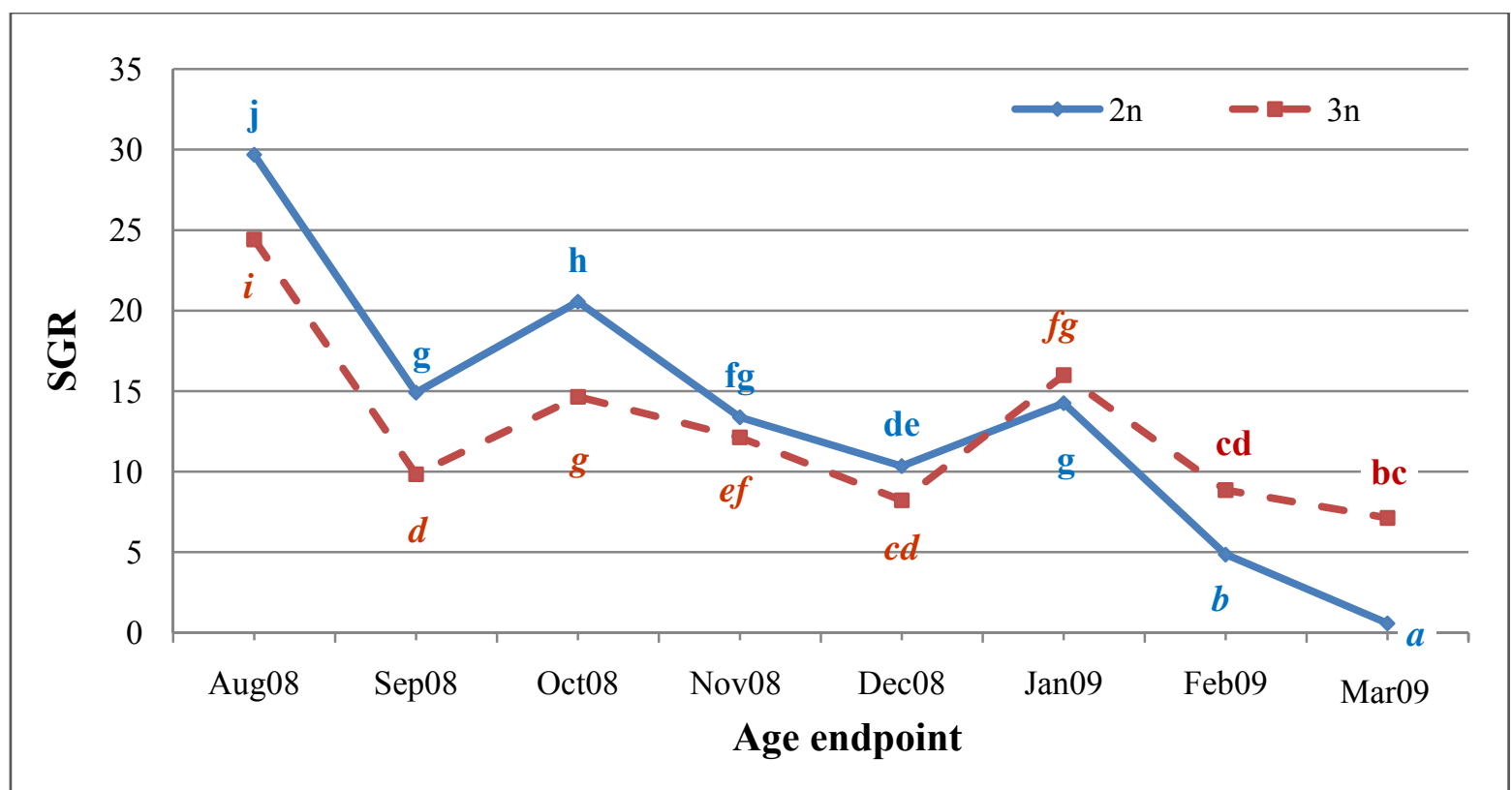

Figure 2 Specific growth rate (SGR) of individually tagged fish as a function of age endpoint. Values are least square means. ${ }^{\mathrm{a}-\mathrm{j}}$ Different letters are different $(P<0.05) . \quad \mathrm{N}=54 . \quad \mathrm{SEM}=1.04(2 \mathrm{~N})$ and $0.91(3 \mathrm{~N})$. 


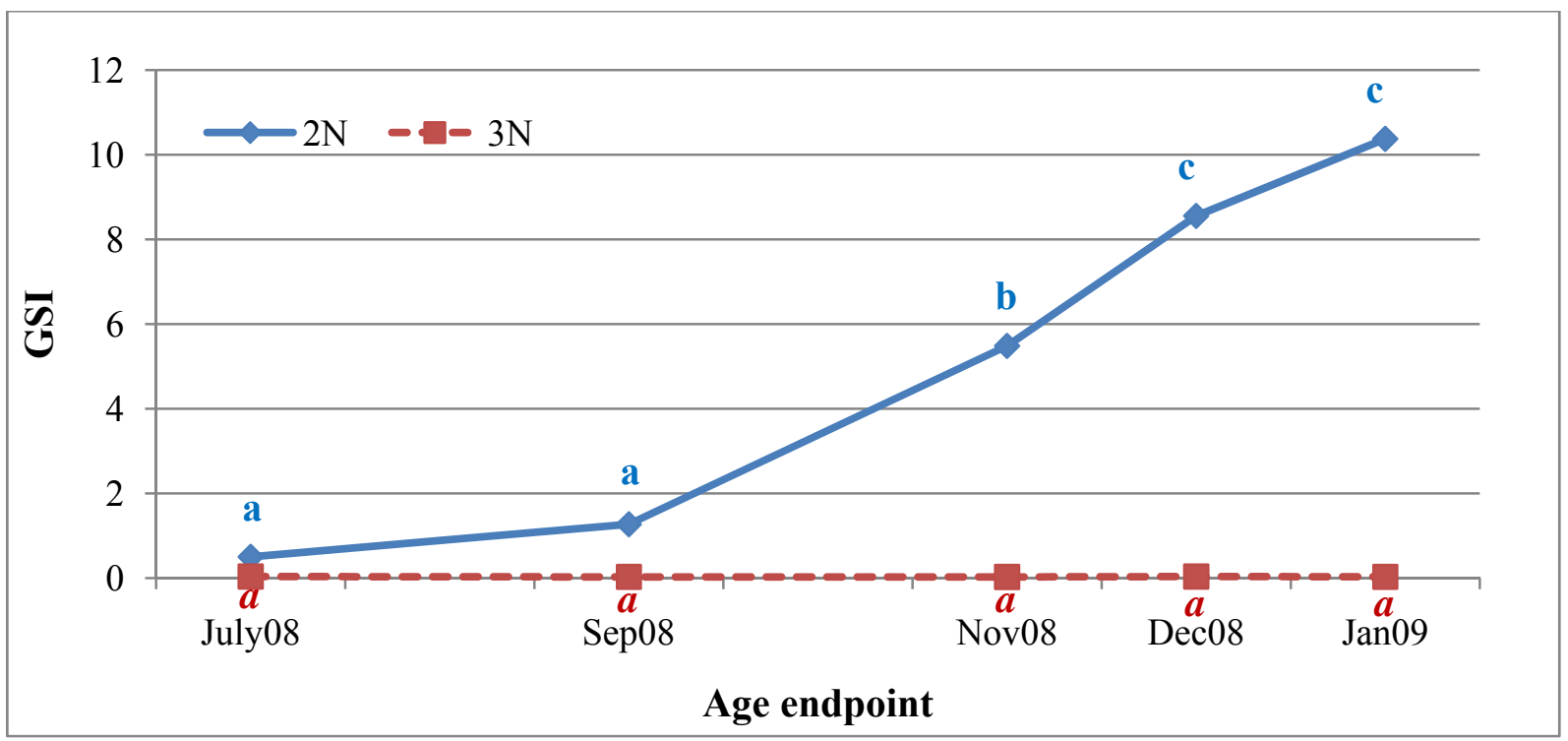

Figure 3 Gonadosomatic index (GSI) of random fish as a function of age endpoint. Values are least square means. ${ }^{a, b, c}$ Different letters are different $(P<0.05) . \quad \mathrm{N}=10$. SEM=0.78. Mean GSI for both groups was not calculated in March because fish was ovulated. 


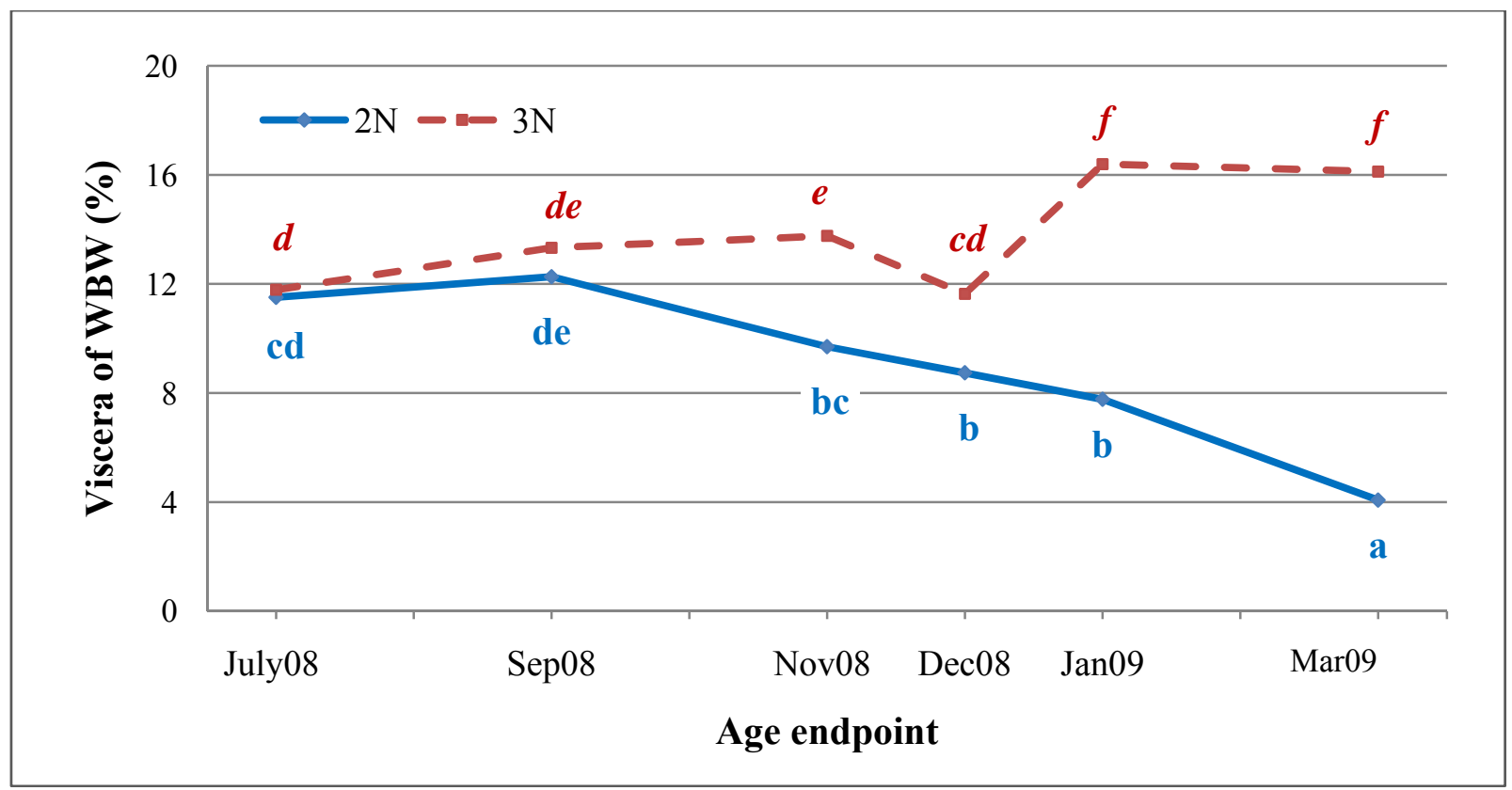

Figure 4 Viscera of whole body weight (WBW; \%) as a function of age endpoint. Values are least square means. ${ }^{\text {a-e }}$ Different letters are different $(P<0.05) . \quad \mathrm{N}=10 . \mathrm{SEM}=0.69$. 


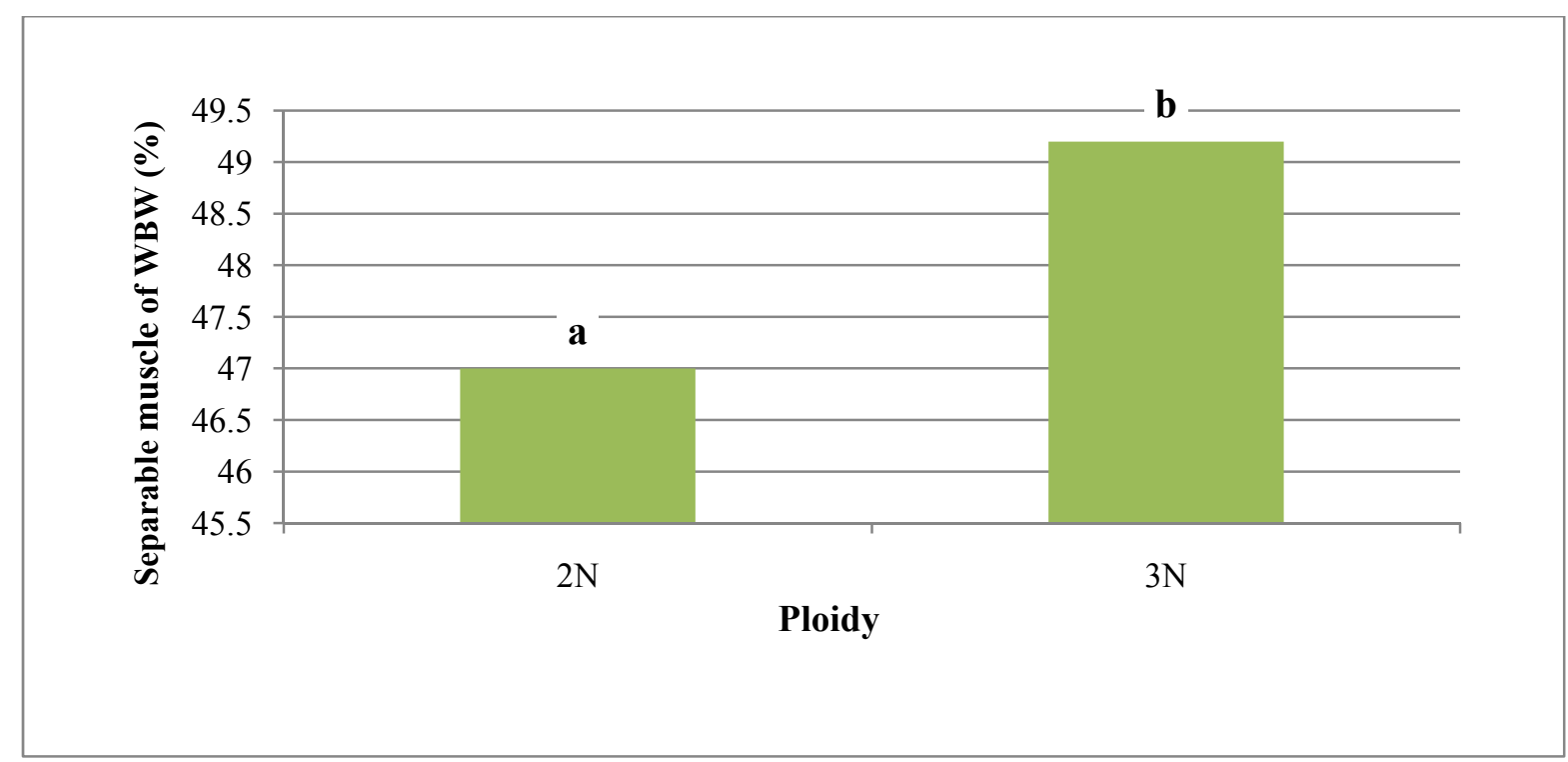

Figure 5 Separable muscle of whole body weight (WBW; \%) as a function of ploidy. Values are least square means. ${ }^{\mathrm{a}-\mathrm{c}}$ Different letters within the same response are different $(P<0.05) . \quad \mathrm{N}=60$. $\mathrm{SEM}=0.63$. 


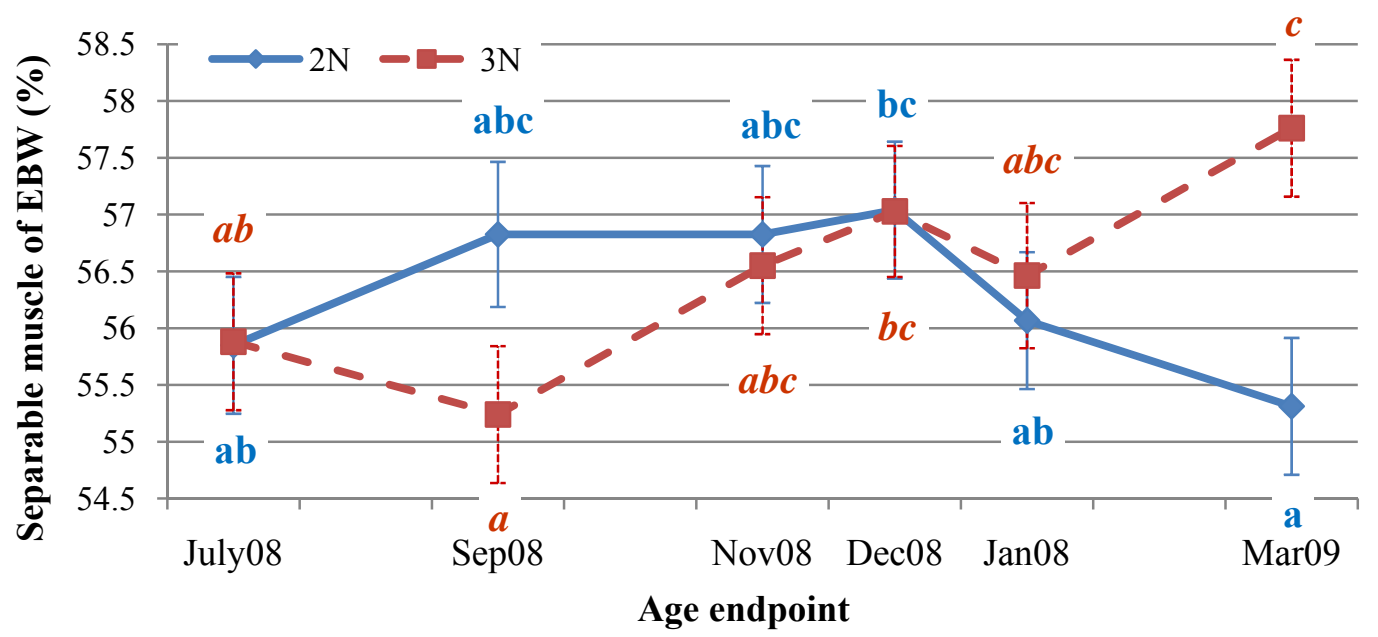

Figure 6 Separable muscle of empty body weight (EBW; \%) as a function of age endpoint. Values are least square means. ${ }^{\mathrm{a}-\mathrm{c}}$ Different letters within the same response are different $(P<0.05) . \quad \mathrm{N}=10$. Each vertical bar represents standard error of mean $(\mathrm{SEM})$. 


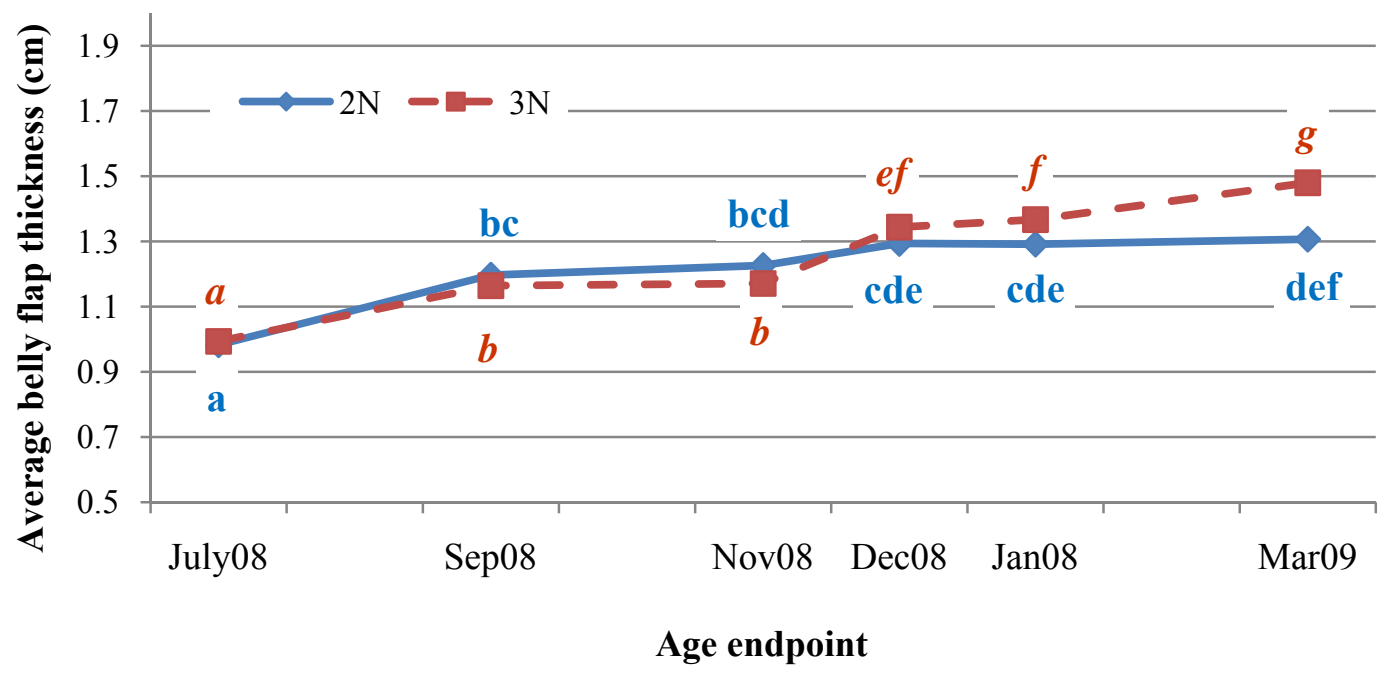

Figure 7 Abdominal wall thickness $(\mathrm{cm})$ as a function of age endpoint. Values are least square means. ${ }^{\mathrm{a}-\mathrm{g}}$ Different letters within the same response are different $(P<0.05) . \quad \mathrm{N}=10 . \quad \mathrm{SEM}=0.04$. 


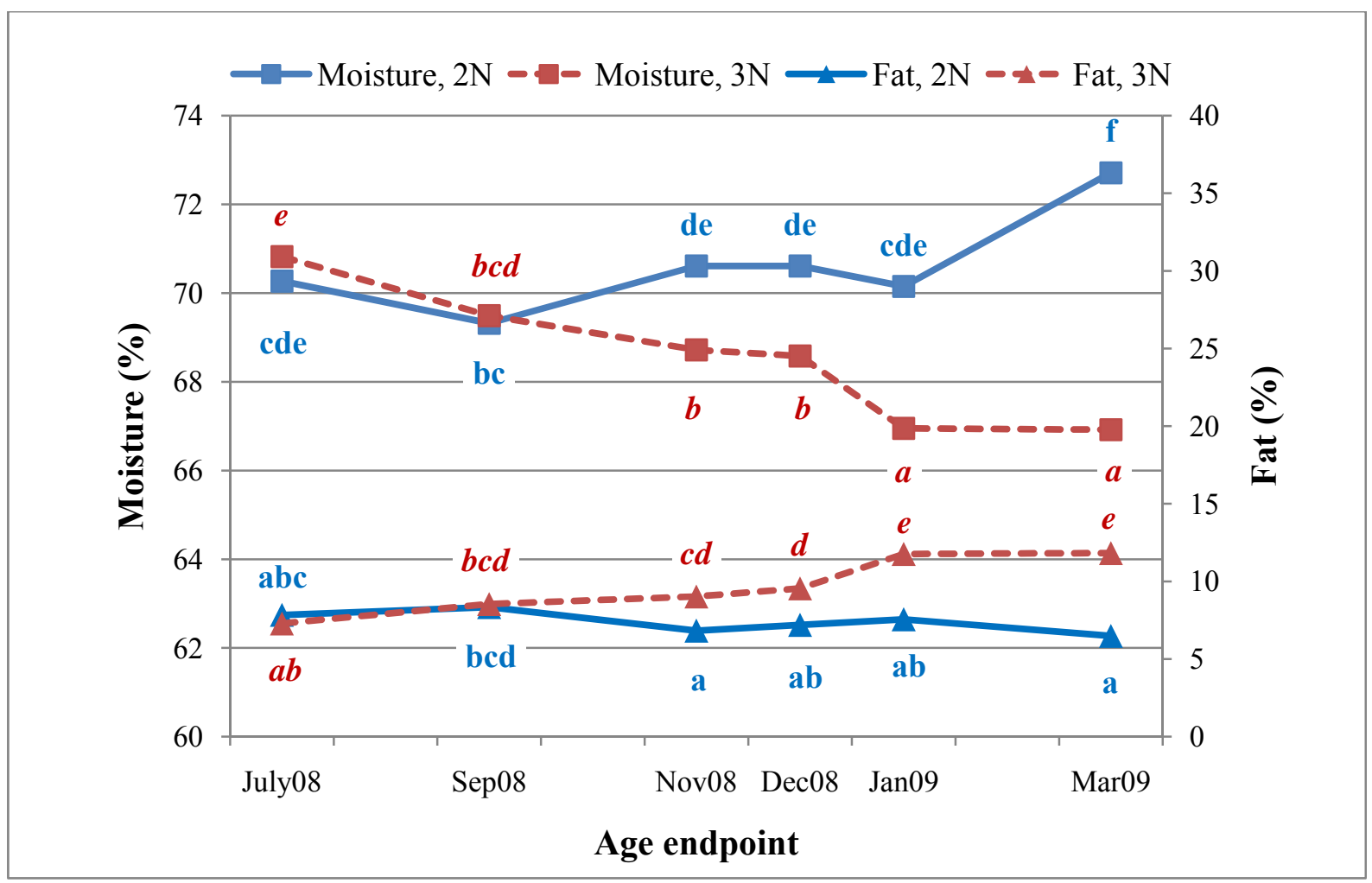

Figure 8 Fat and moisture content (\%) of raw fillets as a function of age endpoint. Values are least square means. ${ }^{\mathrm{a}-\mathrm{f}}$ Different letters within the same response are different $(P<0.05) . \quad \mathrm{N}=10$. $\mathrm{SEM}=0.43$ (moisture) and 0.5 (fat). 


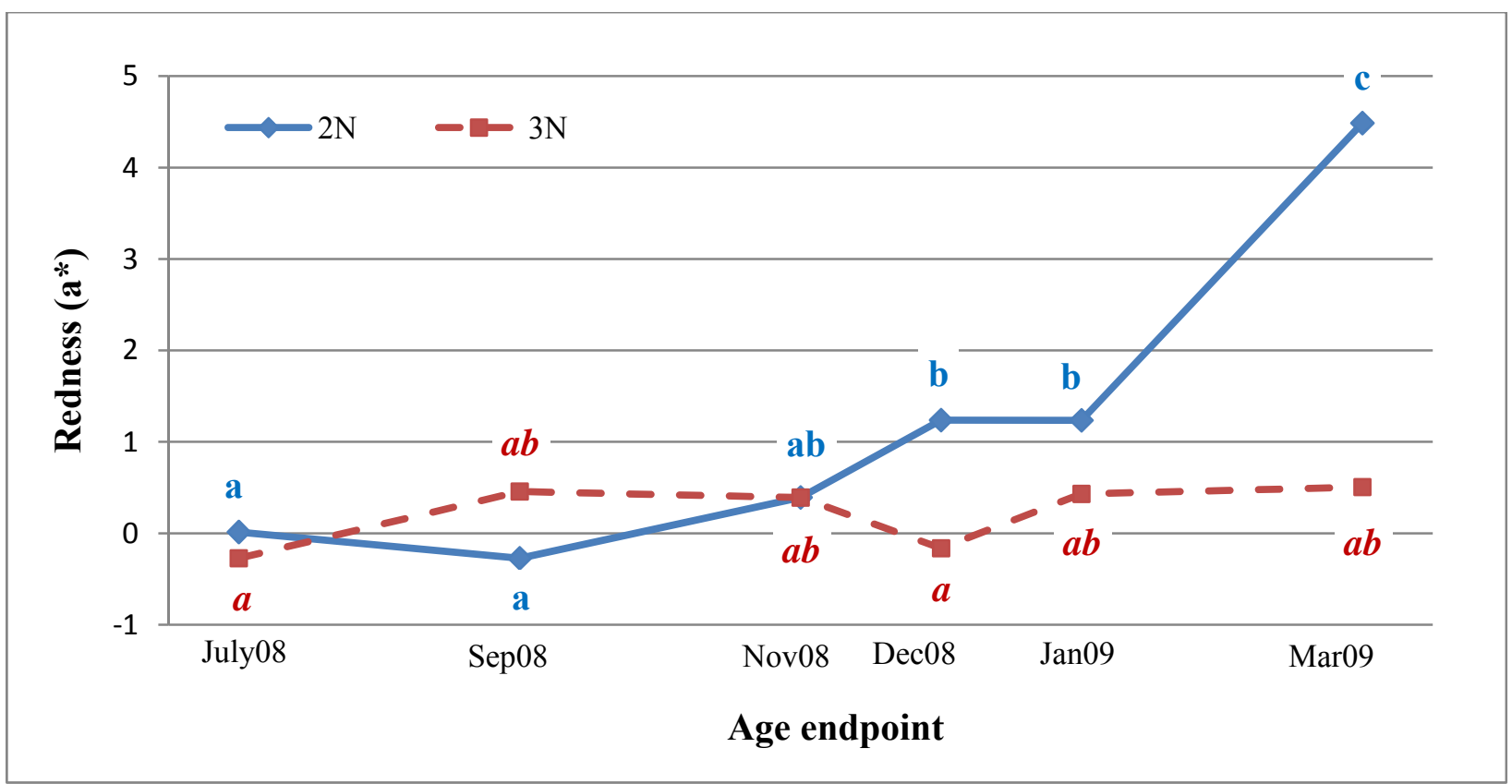

Figure 9 Redness (a*) value of raw fillet surface as a function of age endpoint. Values are least square means. ${ }^{\mathrm{a}-\mathrm{c}}$ Different letters are different $(P<0.05) . \quad \mathrm{N}=10 . \quad \mathrm{SEM}=0.35$. 


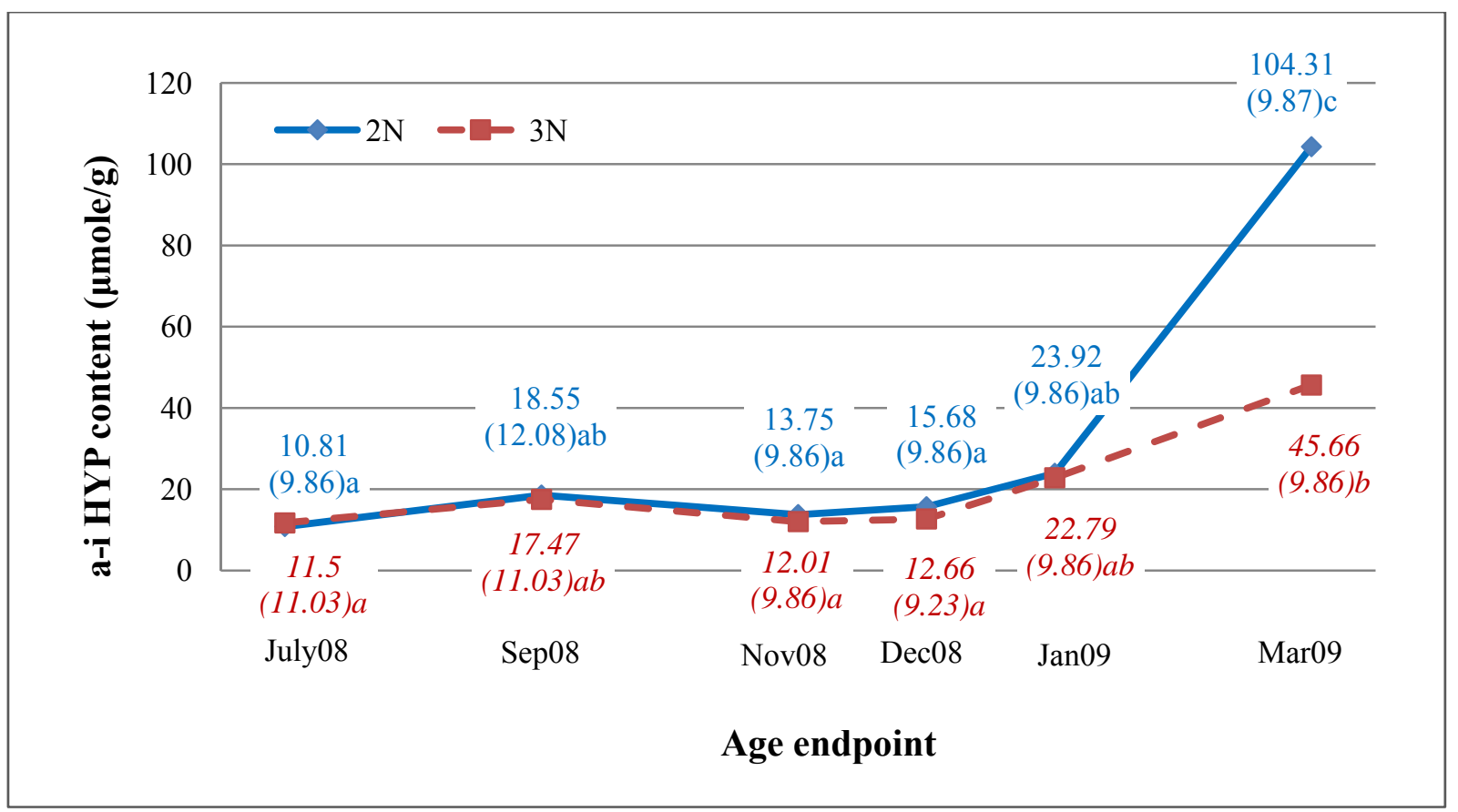

Figure 10 Alkaline-insoluble (a-i) hydroxyproline (HYP) content ( $\mu$ mole/g) of raw fillets as a function of age endpoint. Values are least square means with standard error of mean (SEM) in parenthesis. ${ }^{\mathrm{a}-\mathrm{c}}$ Different letters are different $(P<0.05) . \quad \mathrm{N}=10$. 


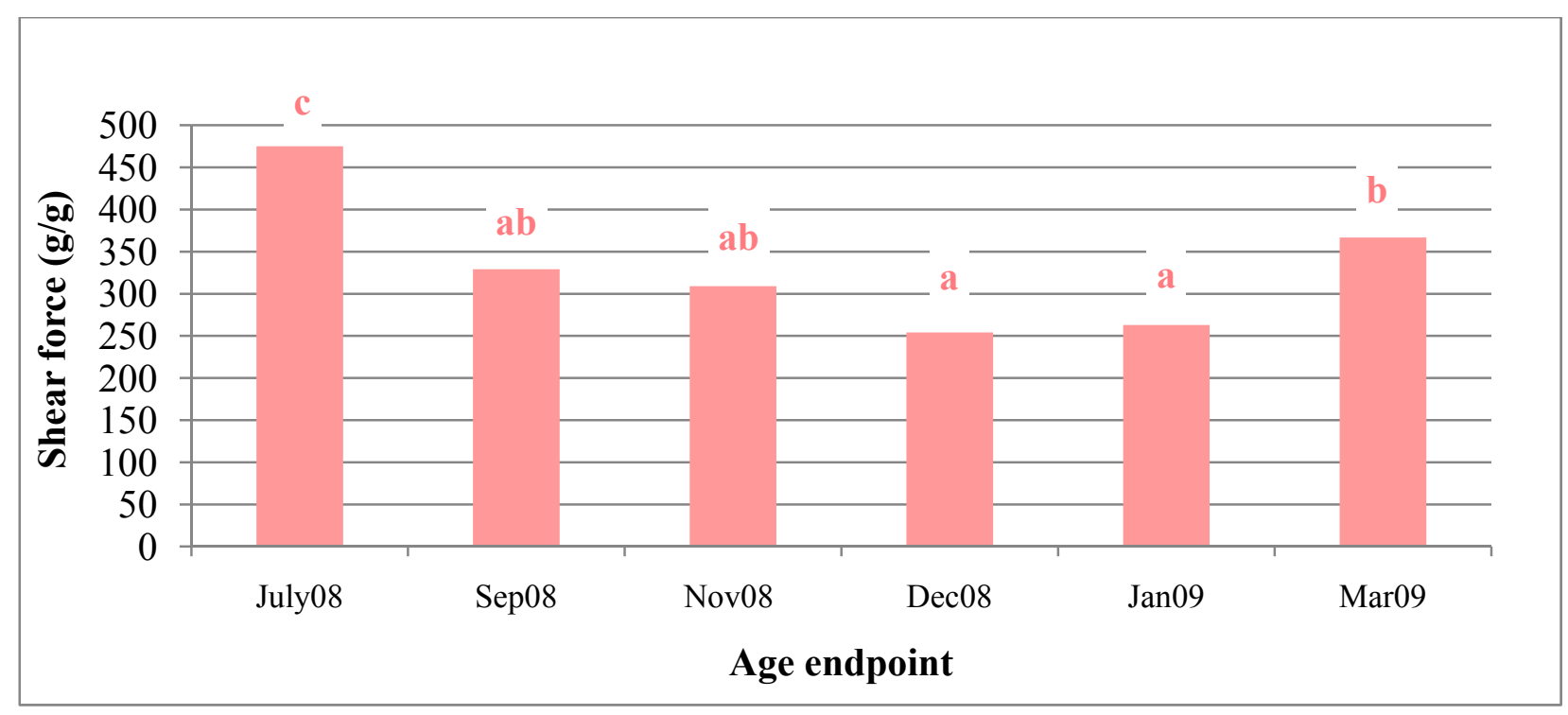

Figure 11 Shear force $(\mathrm{g} / \mathrm{g})$ of raw fillets as a function of age endpoint. Values are least square means. ${ }^{\mathrm{a}-\mathrm{c}}$ Means with different letters are different $(P<0.05) . \quad \mathrm{N}=20 . \quad \mathrm{SEM}=29.59$. 


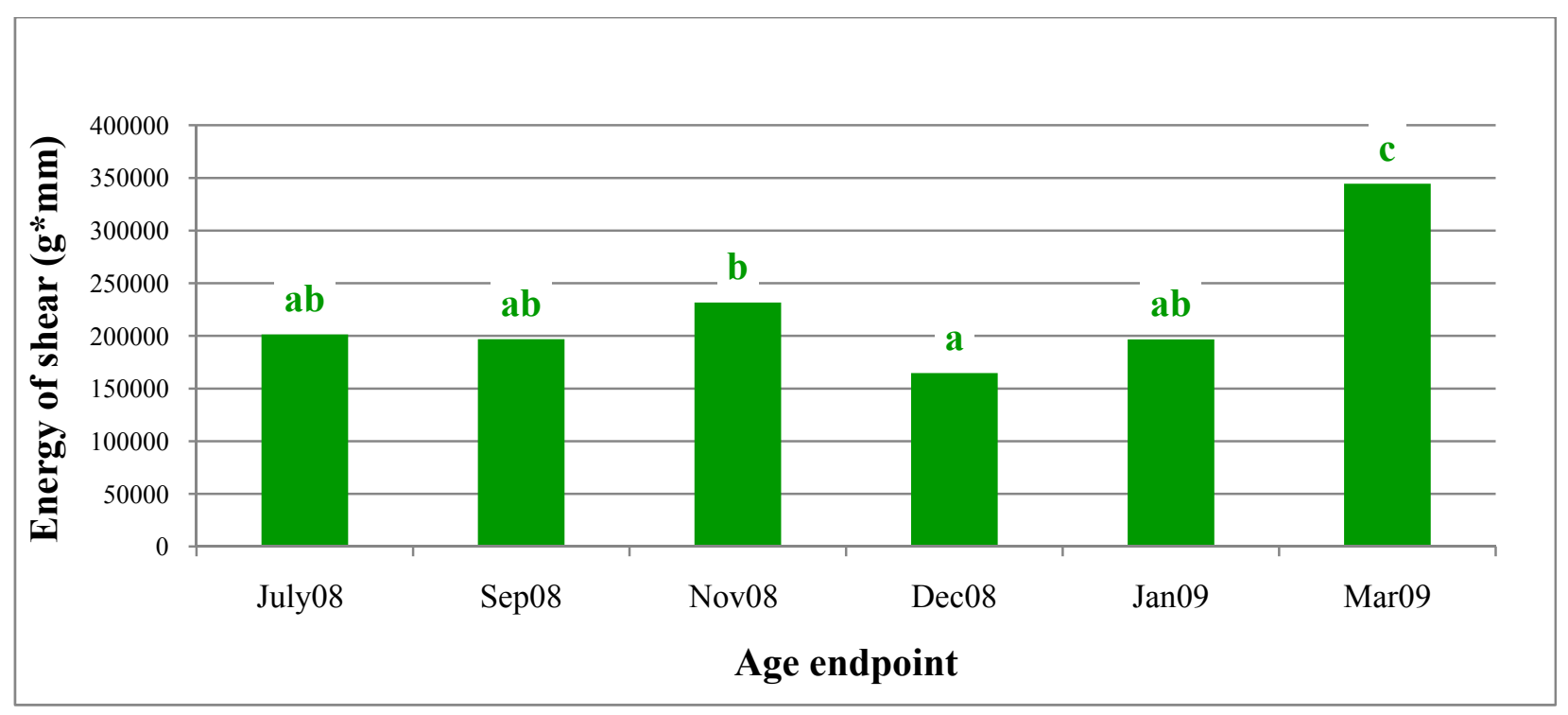

Figure 12 Area or energy of shear $\left(\mathrm{g}^{*} \mathrm{~mm}\right)$ of raw fillets as a function of age endpoint. Values are least square means. ${ }^{\mathrm{a}-\mathrm{c}}$ Different letters are different $(P<0.05) . \quad \mathrm{N}=20$. $\mathrm{SEM}=1.71 \mathrm{E}+03$ for July; 1.25E+04 for Sep, Nov, Jan, and Mar; 1.22E+04 for Dec. 


\section{CHAPTER 3}

Effect of sexual maturation on thermal stability, viscoelastic properties, and texture of rainbow trout, Oncorhynchusmykiss, fillet 


\begin{abstract}
The nutrient and energy demand of sexual maturation in many fish cultivars causes structural change to key contractile proteins and thereby, affects fillet firmness. Thermal denaturation and viscoelastic properties of white muscle from diploid ( $2 \mathrm{~N}$; fertile) and triploid $(3 \mathrm{~N}$; sterile) female rainbow trout were investigated at 6 age endpoints from July 2008 through spawning in March 2009. Differential scanning calorimetry showed, in March, that the actin denaturation temperature $\left(\mathrm{T}_{\text {max,actin }}\right)$ of $2 \mathrm{~N}$ females was higher than that observed in $3 \mathrm{~N}$ females $\left(78.17\right.$ v. $\left.77.27^{\circ} \mathrm{C}\right)$. From 35 to $45^{\circ} \mathrm{C}$, viscoelastic measurement revealed that muscle from $2 \mathrm{~N}$ females and younger fish (July, $16 \mathrm{mo}$ ) had greater elasticity (lower tan $\delta$ ) than muscle from $3 \mathrm{~N}$ females and older fish (November-March; 20-24 mo), respectively. The highest elastic response and the firmest fillets were observed in July. Raw fillets were softer (Allo-Kramer shear; $P<0.05$ ) from September to January $(288.77 \mathrm{~g} / \mathrm{g}$ on average) than those collected in July $(475.15 \mathrm{~g} / \mathrm{g})$ and March (366.79 g/g). Soft fillets became firmer after cooking except for January samples. Greater cook yield and softer fillets were observed in January compared to December. Lipid accumulation in $3 \mathrm{~N}$ females may lubricate muscle fibers and protect them from losing functionality at spawning for animals on a high plane of nutrition.
\end{abstract}

Keywords: Rainbow trout muscle; sexual maturation; thermal denaturation; thermal gelation; texture 


\section{INTRODUCTION}

Sexual maturation often causes softer fillets and decreases muscle yield. Fillet softening involves degradation of muscle protein by lysosomal cathepsins (Ando and others 1986a, b; Crupkin and others 1988; Mommsen 2004; Salem and others 2006). This autolysis is speciesspecific (Ladrat and others 2006); it not only involves the action of proteases but is affected by nutritional background (Love 1988) and inherited adaptation to the reproductive cycle (Kiessling and others 1995). In spawning migration, fish mobilize lipid and white muscle protein stores, replacing lost protein with water to maintain mass and external shape (Mommsen 2004). Thermal denaturation and protein gelation have been used to characterize structural changes in myofibrillar proteins, the key contributors to mechanical strength of fish fillets. Thermally-induced changes in muscle include protein unfolding and a balance that develops between protein-protein, proteinwater, and protein-lipid interactions. Stability of myofibrillar proteins has been described in terms of heat absorption, transition temperature, and elastic and viscous responses of protein gels; these attributes can be related to mechanical strength of gels. Myofibrillar proteins are largely responsible for gelation of muscle foods. Formation of protein gels involves structural changes from native to denatured and, lastly, to aggregated protein (Ferry 1948); this process implies a sequence of orderly events in which denaturation and aggregation occur step by step to reach a highly cross-linked protein matrix (Ferry 1948; Acton and Dick 1984). Heat-induced changes in muscle proteins can be measured by development of gel rigidity during continuous heating while applying small, nondestructive strains (Foegeding 1988). Gelation of myofibrillar proteins is of particular interest in fish due to the low collagen content of fish muscle. Changes in actomyosin composition of mature hake are influenced by its metabolic state and related to its reproductive cycle (Crupkin and others 1988); actomyosin from post-spawned fish had higher ATPase 
activities, reduced viscosity and better gelling properties than actomyosin from pre-spawned fish (Beas and others 1988; Roura and others 1990). Roura and others (1992) reported a loss of the filamentous structure in actomyosin from pre-spawned hake which was related to a decrease in the affinity between myosin and actin. In flounder, thermal stability of actomyosin is also influenced by reproductive cycle (Paredi and Crupkin 2007).

This study was conducted to determine changes in thermal stability and viscoelastic properties of muscle proteins and their relationship to texture of fillets from fertile (diploid; $2 \mathrm{~N}$ ) and sterile (triploid; $3 \mathrm{~N}$ ), female rainbow trout on a high nutritional plane and during the normal time of sexual maturation in diploids. Age endpoints selected for these analyses covered the period from egg growth and development through spawning. Indices of thermal denaturation and gel forming ability of whole muscle would be related to changes in instrumental texture measurement. We found that changes in raw fillet texture of trout females on a high plain of nutrition occurred in two periods: 1) softer fillets were observed during egg growth and development (November - January; 20 - $22 \mathrm{mo}$ ) and 2) fillet firmness increased during spawning (January - March; 22 - 24 mo; Aussanasuwannakul and others 2011). Nonetheless, muscle protein content and raw fillet texture did not change $(P>0.05)$ in these females due to an age endpoint*ploidy effect, suggesting that there were other, unexplained sources of variation in texture. Thermal denaturation and viscoelastic characterization of these muscle samples might reveal changes in stability and gelling properties of muscle proteins. 


\section{MATERIALS AND METHODS}

\section{Animal Care and Fillet Processing}

Eggs and sperm were collected from two rainbow trout families reared at the National Center for Cool and Cold Water Aquaculture (NCCCWA; U.S. Department of Agriculture, Agricultural Research Service) in Leetown, West Virginia; these stocks were obtained two generations earlier from Troutlodge Inc. (Sumner, WA). Triploid induction was accomplished by applying 9,000 psi $\left(633 \mathrm{~kg} / \mathrm{in}^{2}\right)$ of hydrostatic pressure for eight minutes to a subset of the eggs from each cross for thirty minutes post fertilization (Palti and others 1997). Embryos were incubated at $10 \pm 0.5^{\circ} \mathrm{C}$, and abnormalities were removed through first feeding. Each group was transferred and raised in separate, 61-cm tanks until large enough to tag. In May 2008, fish were placed in five, randomly assigned tanks (122-cm diameter). They were fed with a commercial feed (Zeigler GOLD Floating $5.0 \mathrm{~mm}$ pelleted feed; Zeigler Brothers, Inc.; Gardners, Pennsylvania, U.S.A.) throughout the course of the experiment. The feed contained 42,16 , and $2 \%$ crude protein, fat, and fiber, respectively. Fish were fed on a tank-by-tank basis daily by a belt feeder. The amount of feed was altered depending on appetite. At the end of each day, fish were fed by hand to apparent satiation. This feeding regimen is indicative of a high plane of nutrition. Each of the five tanks was stocked with thirty-five fish, totaling 175 fish for this study. These thirty-five fish consisted of about the same number of fish of each ploidy ( $2 \mathrm{~N}$ and $3 \mathrm{~N}$ ) from each family. Water was continuous-flow groundwater, with ambient temperatures ranging between 12 and $13.5^{\circ} \mathrm{C}$, and dissolved oxygen content was near air saturation. Photoperiod was maintained with artificial lighting, which was adjusted weekly to follow the ambient photoperiod.

Five fish from each of 2 family by 2 ploidy ( $2 \mathrm{~N}$, fertile; and $3 \mathrm{~N}$, sterile) combinations ( 5 fish $\mathrm{x} 4$ combinations $=20$ fish) were sampled at six age endpoints in July, September, November, 
and December 2008; and January and March 2009. These six sampling points marked age endpoints of 16,18,20,21,22, and 24 months post hatching, respectively. At each of six sampling periods, fish were shifted to a different tank to further reduce bias associated with tank. Fish were held off feed 24 hours prior to sampling and were anesthetized using tricaine-S at the NCCCWA. Fish care and experimentation followed the guidelines outlined by U.S. Dept. of Agriculture (USDA) and the NCCCWA Animal Care and Use Committee, which are in line with the National Research Council publication Guide for Care and Use of Laboratory Animals.

White muscle samples $(\sim 20 \mathrm{~g})$ were collected from the dorsal musculature, flash frozen in liquid nitrogen, and transferred to a $-80^{\circ} \mathrm{C}$ freezer for thermal denaturation analysis by differential scanning calorimetry (DSC). Fish were stored on ice for delivery to Morgantown, WV, an approximate 3.5-hour trip. Fish were subsequently stored in coolers with ice overnight before filleting, approximately 18 hours after harvest. Two, $40 \times 80 \mathrm{~mm}$, skinless fillet sections were taken from the dorsal musculature, $2-3 \mathrm{~cm}$ caudal to the pectoral girdle, of randomly selected right or left fillet halves. The remaining muscle from the fillets was pulverized with liquid nitrogen in a Waring Blender (Waring, New Hartford, CT, U.S.A.) and kept at $-25{ }^{\circ} \mathrm{C}$ for compositional analysis and dynamic viscoelastic measurement.

For cooked muscle evaluation, fillet sections were thermally processed in a microprocessor-controlled smoke oven (Model CVU-490; Enviro-Pak, Clackamas, OR, U.S.A.) set at $82{ }^{\circ} \mathrm{C}$, and the cooking process was stopped when the internal fillet temperature reached 65.5 ${ }^{\circ} \mathrm{C}$. This cooking temperature was selected according to the USDA recommended, minimum internal temperature for fish to achieve a safe temperature without overcooking (Food Safety Education 2010). Total cooking time was approximately 45 minutes. After cooking and when 
product reached room temperature, weight was determined for raw and cooked sections, and cook yield was calculated.

\section{Differential Scanning Calorimetry}

Deep frozen muscle was tempered on ice for 30 minutes to facilitate cutting. Using a razor blade, one milligram of white muscle was taken, perpendicular to the muscle fiber, from a myotome section while avoiding the connective tissue of the myosepta. Each muscle sample was placed in a hermetically sealed pan (PS1007; Instrument Specialists Inc., Twin Lakes, WI, U.S.A.). Thermal stability of muscle proteins was determined using differential scanning calorimetry (DSC Q100; TA Instruments, New Castle, DE, U.S.A.). The instrument was calibrated for temperature and base-line using indium as the standard. Samples were scanned from 20 to $105^{\circ} \mathrm{C}$ at a heating rate of $1^{\circ} \mathrm{C} \mathrm{min}^{-1}$. Data were collected and thermal denaturation indices were calculated from the resulting thermogram using Universal Analysis V4.2 E software (TA Instruments) including 1) onset melting temperature $\left(\mathrm{T}_{\mathrm{m}}\right)$ of an endothermic peak which indicates the beginning of protein denaturation, 2$)$ temperature at maximum heat flow $\left(\mathrm{T}_{\max }\right)$ recorded at the peak of the endotherm which represents the temperature corresponding to maximum rate of heat input, and 3) total enthalpy change $(\Delta \mathrm{H})$ associated with protein denaturation which was recorded from the area above the DSC transition curve. All measurements were determined at least in duplicate.

\section{Dynamic Viscoelastic Measurement}

Powdered muscle samples of individuals from the family with a lower fat content $(6 \% \mathrm{v}$. $11 \%)$ were manually made into a paste. The rheological measurements of this muscle paste were performed with a controlled-stress rotational rheometer (RMS800, Rheometric Scientific) in 
oscillatory mode $(1 \mathrm{rad} / \mathrm{sec})$. Muscle paste was heated between parallel plates $($ diameter $=2.5 \mathrm{~cm}$, gap $=2 \mathrm{~mm}$ ) from 25 to $105^{\circ} \mathrm{C}$ at $2^{\circ} \mathrm{C} / \mathrm{min}$. Viscoelastic measurements were carried out with a maximal deformation of $0.2 \%$ in a nondestructive mode. Rheological properties of muscle samples, determined from shear stress-time curves in the linear viscoelastic region, included 1) elastic modulus (G') which is the stress component that is in phase with the shear strain and measures solid-like character of muscle samples and 2) loss tangent ( $\tan \delta$ ) which is the lag of shear stress behind the strain by an angle of difference $(\delta)$ that lies between $0^{\circ}$ and $90^{\circ}$ with the shear strain. Tan $\delta$ is an indicator of solid/liquid-like character of muscle samples; $0^{\circ}$ is characteristic of a purely elastic (solid) material and $90^{\circ}$ is characteristic of a purely viscous (liquid) material. Sample dehydration was prevented by addition of paraffin oil.

\section{Chemical Composition and Cook Yield Measurement}

$\mathrm{pH}$ and proximate composition of powdered, raw muscle were determined using AOAC (1990) approved methods. Cooked weight was expressed as a percentage of the raw weight and designated as percent cook yield.

\section{Instrumental Texture Measurement}

Texture of fillet sections was measured using a 5-blade, Allo-Kramer shear attachment mounted to the TA-HDi ${ }^{\circledR}$ Texture Analyzer (Texture Technologies Corp., Scarsdale, NY, U.S.A.) which was equipped with a $50-\mathrm{kg}$ load cell and ran at a crosshead speed of $127 \mathrm{~mm} / \mathrm{min}$. Shear force was applied perpendicularly to the muscle fiber orientation. Force-deformation graphs were recorded and maximum shear force (g/g sample) was determined using the Texture Expert Exceed software (version 2.60; Stable Micro Systems Ltd., Surrey, U.K.). 


\section{Experimental Design and Statistical Analysis}

This experiment was conducted in the context of a $2 \times 6 \times 2$ randomized complete block design with a fixed block effect (family). Fixed effect factors included six age endpoints (July, September, November, December 2008; and January and March 2009) and two ploidy conditions (diploid, 2N; and triploid, 3N). Five fish were randomly assigned to each of four treatment combinations (two ploidy levels $\mathrm{x}$ two families) at each age endpoint. Therefore, each treatment combination was repeated five times on randomly selected fish. DSC data were collected from July, January, and March samples. Dynamic viscoelastic data were collected in July, November, January, and March; because muscle from only one family was chosen, we did not consider family as a treatment effect for this analysis. Data were analyzed by analysis of variance (ANOVA) using the Mixed Model (MIXED) procedure of SAS ${ }^{\circledR}$ system for Windows, version 9.1 (SAS Institute Inc 2004). Relationships among independent variables were analyzed by Pearson product-moment correlation analysis using CORR procedures of $\mathrm{SAS}^{\circledR}$ system for Windows, version 9.1 (SAS Institute Inc 2004). Significance was defined at $P<0.05$. 


\section{RESULTS AND DISCUSSION}

\section{Thermal denaturation of trout muscle proteins}

DSC thermograms of whole muscle revealed two major endothermic transitions at 38 to $45^{\circ} \mathrm{C}$ and 77 to $79^{\circ} \mathrm{C}$ (Figure 1). These ranges of transition temperature are typical of muscle and have been attributed to denaturation of the myosin head (or heavy meromyosin) and actin, respectively (Stabursvik and Martens 1980; Srinivasan and others 1998). Mean values of thermal properties, categorized by ploidy and age endpoint are presented in Table 1. On average, onset melting temperature $\left(\mathrm{T}_{\mathrm{m}}\right)$ decreased from $36.2^{\circ} \mathrm{C}$ in July to $34.7^{\circ} \mathrm{C}$ in January, and increased to $38.1^{\circ} \mathrm{C}$ in March $(P=0.3713)$. An age endpoint*ploidy effect on temperature at maximum heat flow for actin $\left(\mathrm{T}_{\text {max,actin }} ; P=0.0081\right.$; Table 1$)$ suggested that egg growth and development affected thermal properties of this contractile protein. Muscle protein of $2 \mathrm{~N}$ females maintained its stability through sexual maturation, and the higher $\mathrm{T}_{\text {max,actin, by }} 1^{\circ} \mathrm{C}$, for $2 \mathrm{~N}$ actin than actin in March suggested a possible contribution of actin to the stability or preservation of contractility of the actomyosin complex in $2 \mathrm{~N}$ females through spawning. We also found an effect of age endpoint on enthalpy of actin denaturation $\left(\Delta \mathrm{H}_{\text {actin }} ; \mathrm{P}=0.0121\right) ; \Delta \mathrm{H}_{\text {actin }}$ in July, January, and March were 0.21, 0.31 , and $0.20 \mathrm{~J} / \mathrm{g}$, respectively. The highest $\Delta \mathrm{H}_{\mathrm{actin}}(0.31 \mathrm{~J} / \mathrm{g})$ in January agreed with the relatively higher $\mathrm{T}_{\max \text {,actin }}\left(78.2^{\circ} \mathrm{C}\right.$ on average) in January compared to July and March. There was no evidence that egg growth and development affected enthalpy of denaturation of either myosin (age endpoint*ploidy effect; $P=0.6602$ ) or actin (age endpoint*ploidy effect; $P=0.7180$ ). Sano and others (1989) reported that filamentous actin directly induced a decrease in storage modulus, which results from the dissociation of some myosin molecules from the actin filament and from the fragmentation of the actin filament. 
Variation in muscle protein content, especially myofibrillar protein, influences thermal stability and gel forming ability of fish muscle (Xiong 1994; Boyer and others 1996; Hashimoto and others 2004) more than lipid content. However, we found in the present study that, in well-fed female rainbow trout, sexual maturation did not affect myosin thermal properties. Kiessling and others (1995) reported that, during spawning migration, rainbow trout preserved the fast twitch isoform of myosin heavy chain in white muscle as energy metabolism shifted from glucose to lipid. In the present study, the fast twitch isoforms of myosin heavy chain may have been preserved. At the same time, we found that lipid was the most variable component of muscle, softening fillet texture during egg growth and development. Transient, but significant changes in muscle fat content occurred in $2 \mathrm{~N}$ females, including an $18 \%$ decrease in fillet fat content from September to November; inverse and greater changes in fat content were observed for $3 \mathrm{~N}$ fish including a 23\% increase in fillet fat content from December to January (Figure 2). In salmon, fat, membrane remnants, and amorphous material filled the intra- and extracellular spaces associated with greater stability of the myosin-actomyosin complex and better liquid-holding capacity compared to the lean muscle of cod (Ofstad and others 1996). In the present study, lipid may have played a role in stabilizing the myofibril and actomyosin during egg growth and development. Bound water has been related to thermal properties and stability of muscle protein (Penny 1969; Liu and others 1991; Deng and others 2002; Brewer 2004; Wrolstad and others 2004; Zhou and others 2008). In the present study, moisture content represents bound and free forms of water that are inversely related to changes in fat content. Additionally, it appears that catabolism of protein was not necessary, given lipid stores, to support egg growth in $2 \mathrm{~N}$ female. Proteolytic degradation of myosin heavy chain during post mortem storage has been characterized by immunoblotting using polyclonal antibodies (Wang and others 2009) and changes in protein staining pattern 
(literatures cited by Wang and others 2009). However, there is limited research, to date, relating thermal stability of myosin or myofibrillar proteins to catabolic changes in proteins resulting from vitellogenesis.

\section{Viscoelastic properties of trout muscle proteins}

Thermal gelation profiles are presented by elastic modulus $\left(\mathrm{G}^{\prime}\right)$ and loss tangent $(\tan \delta)$ for muscle samples from 2N (Figure 4) and 3N (Figure 5) females harvested at four age endpoints. Mean values of storage modulus and $\tan \delta$, at selected temperature regions and categorized by age endpoint and ploidy, are also presented in Table 2. Because greater protein-protein interaction will allow greater opportunity to observe the role of myofibrillar protein in gel formation, we used muscle samples from the family with a lower fat content (6\%), to minimize effect of fat on gelation of muscle protein samples.

Muscle samples from 3N females (Figure 5) exhibited more variation in viscoelastic properties, as a function of age endpoint, than $2 \mathrm{~N}$ females (Figure 6). Above $45^{\circ} \mathrm{C}$ in the $3 \mathrm{~N}$ thermal profile (Figure 5), $\tan \delta$ gradually increased with age, indicating reduced elasticity of the myofibril. Muscle samples collected in March were the least elastic. Statistical analysis showed that, from 35 to $40^{\circ} \mathrm{C}, \tan \delta$ of $2 \mathrm{~N}$ muscle was lower than that of $3 \mathrm{~N}$ muscle indicating that $2 \mathrm{~N}$ muscle was more elastic $(P<0.05$; Table 2$)$. At $45^{\circ} \mathrm{C}$, muscle from younger fish (July; $16 \mathrm{mo}$ ) yielded a higher elastic response $(P<0.05)$. Since myosin is a key contributor to heat-induced protein gels, loss of elastic component in March samples suggested that myosin functionality in actomyosin complex could be modified. Myofibrillar protein gel strength increases exponentially with protein concentration (Xiong 2004). The highest elasticity of July muscle agreed with its highest protein content relative to other age endpoints (23.38\% v. $20.77 \%$; $P=0.0004)$. 


\section{Relating muscle thermal denaturation and viscoelastic properties to instrumental texture measurement}

Shear force $(\mathrm{g} / \mathrm{g})$ was determined on raw and cooked fillets of $2 \mathrm{~N}$ and $3 \mathrm{~N}$ females at six age endpoints (Figure 6). Significant age endpoint*cooking state effects were observed $(P<0.0001)$. Raw fillets were softer $(P<0.05)$ from September to January $(288.77 \mathrm{~g} / \mathrm{g})$ than those collected in July (475.15 g/g) and March (366.79 g/g). During the five months prior to spawning (March; $24 \mathrm{mo}$ ) for these females that were on a high nutritional plane, we observed an increased accumulation of muscle fat in $3 \mathrm{~N}$ individuals; this change in composition may explain a decrease in firmness of raw fillets. Soft fillets were firmer after cooking except for the January endpoint. In cooked fillets, water loss due to evaporation and drip may contribute to increased firmness. A substantial increase in cooked fillet firmness was due to denaturation of muscle fibers and water loss (Schubring 2008). In January, the difference in shear force between raw and cooked fillets was not as substantial as that observed in September, November, and December. In January, the difference between raw and cooked texture is supported by increased cook yield $(P<0.05)$. Greater cook yield means greater retention of water and fat, thus contributing to a softer cooked fillet. It is possible that less water was lost during cooking, and the muscle protein's ability to immobilize or trap water within the fillet was improved. We observed that fat content is a key contributor to variation in fillet texture; fat content negatively correlated with shear force $(\mathrm{r}=-0.35, P=0.0005)$, explaining $12 \%$ of the total variation (Aussanasuwannakul and others 2011). Increased muscle fat appeared to be a key factor in reducing shear force of cooked fillets from $641.01 \mathrm{~g} / \mathrm{g}$ in December to $353.90 \mathrm{~g} / \mathrm{g}$ in January; shear force increased again in March $(459.63 \mathrm{~g} / \mathrm{g})$, consistent with an increase in shear force of raw fillets. About thirty-six percent greater fat in $3 \mathrm{~N}$ muscle in January than December may decrease firmness of raw fillets, increase cook yield, and soften cooked fillets. 
Lipids may preserve protein stability and actin-myosin interaction (Taguchi 1970). A decrease in total lipids of actomyosin from pre- to post-spawned hake muscle coincided with a decrease in surface hydrophobicity of actomyosin (Roura and others 1992) and loss in myosin functionality (Busalmen and others 1995). Hamada and others (1982) found that lipid preserved myofibrillar protein stability by binding to and stabilizing actomyosin, thereby decreasing the heat denaturation rate. Triacylglycerol melting properties are affected by fatty acid composition and their distribution within the glyceride molecule (Belitz and others 2009). Polyunsaturated fatty acids are important to egg growth and development in several fish species (Sargent and others 1999; Salze and others 2005) and found to be mobilized during sexual maturation in rainbow trout (Nassour and Leger 1989). Therefore, it is possible that variation in fatty acid composition during sexual maturation and differences in melting temperatures of individual fatty acids influence thermal properties of muscle, indirectly, in the present study.

We used dynamic viscoelastic measurement and instrumental texture measurement to describe contributions of lipid and protein to shear deformation in a different context. In instrumental texture evaluation, shear deformation was characterized in the context of in situ muscle structure in which key components including lipid, contractile protein, and moisture, exist in separate domains. In, the rheological test, shear deformation was characterized in the context of a homogeneous system in which interaction of these components contributed to formation or destabilization of the protein gel network. Therefore, lipid's contribution to instrumental shear deformation of trout muscle could be explained by lubricating muscle fibers that began in November $(20 \mathrm{mo})$ and seemed to offset muscle protein's water-holding capacity at the time of spawning in females (March; $24 \mathrm{mo}$ ) which would otherwise yield cooked fillets with increased 
firmness. On the other hand, thermal stability and viscoelastic properties suggest a role of lipid in protein stability through its contribution in heat absorption. 


\section{CONCLUSION}

Fillets of maturing females (July; $16 \mathrm{mo}$ ) were firmer due to an increased elastic component of muscle. Lipid accumulation lubricated muscle and softened fillet texture during periods of egg growth and development (November-January; 20-22 mo) specific to these $2 \mathrm{~N}$ females that were on a high nutrition plane. Muscle fat insulated muscle fibers and preserved their functionality at the time of spawning in females (March; 24 mo). 


\section{REFERENCES}

Acton JC, Dick RL. 1984. Protein-protein interaction in processed meats. 37th Ann Reciprocal Meat Conf Proc 37(1):36-43.

Ando S, Yamazaki F, Hatano M, Zama K. 1986a. Deterioration of chum salmon (Oncorhynchusketa) muscle during spawning migration - III. Changes in protein composition and protease activity of juvenile chum salmon muscle upon treatment with sex steroids. Comp Biochem Physiol 83B(2):325-30.

Ando S, Hatano M, Zama K. 1986b. Protein degradation and protease activity of chum salmon (Oncorhynchusketa) muscle during spawning migration. Fish Physiol Biochem 1(1):1726.

AOAC. 1990. Official Methods of Analysis. 15th ed. Washington, DC: Association of Official Analytical Chemists.

Beas VE, Crupkin M, Trucco RE. 1988. Gelling properties of actomyosin from pre- and postspawning hake (Merlucciushubbsi). J Food Sci 53:1322-6.

Belitz H-D, Grosch W, Schieberle P. 2009. Food Chemistry. Germany: Springer. 1070p.

Boyer C, Joandel S, Ouali A, Culioli J. 1996. Determination of surface hydrophobicity of fast and slow myosins from rabbit skeletal muscles: Implication in heat-induced gelation. J Sci Food Agric 72:367-75.

Brewer MS. 2004. Chemical and physical characteristics of meat / Water-holding capacity. In: Jensen WK, editor. Encyclopedia of meat sciences. Elsevier Ltd. p 242-9.

Busalmen JP, Roura SI, Roldan H, Crupkin M. 1995. Changes in lipids and biochemical properties of actomyosin from pre- and post-spawned hake (Merlucciushubbsi Marini). Comp Biochem Physiol 112B(4):743-8.

Crupkin M, Montecchia CL, Trucco RE. 1988. Seasonal variations in gonadosomatic index, liversomatic index and myosin/actin ratio in actomyosin of mature hake (Merlucciushubbsi). Comp. Biochem. Physiol. 89A(1):7-10.

Deng Y, Rosenvold K, Karlsson AH, Horn P, Hedegaard J, Steffensen CL, Andersen HJ. 2002. Relationship between thermal denaturation of porcine muscle proteins and water-holding capacity. J Food Sci 67(5):1642-7.

Ferry JD. 1948. Protein gels. Adv Protein Chem 4:1-78.

Foegeding EA. 1988. Thermally induced changes in muscle proteins. Food Technol 5(6):58-64. 
Food Safety Education: Is It Done Yet? [Internet]. Washington, DC: Food Safety and Inspection Service, United States Department of Agriculture; 2006 May 9 [2010 Mar 13]. Available from: http://www.fsis.usda.gov.

Hamada I, Yabuno F, Furrumatsu K, Niwa E. 1982. The effect of lipid on the heat denaturation of actomyosin. Bull Jap Soc Sci Fish 48:189-93.

Hashimoto T, Suzuki T, Hagiwara T, Takai R. 2004. Study on the glass transition for several processed fish muscles and its protein fractions using differential scanning calorimetry. Fisheries Sci 70:1144-52.

Kiessling A, Larsson L, Kiessling K-H, Lutes PB, Storebakken T, Hung SSS. 1995. Spawning induces a shift in energy metabolism from glucose to lipid in rainbow trout white muscle. Fish Physiol Biochem 14(6):439-48.

Ladrat CD, Cheret R, Taylor R, Bagnis VV. 2006. Trends in postmortem aging in fish: understanding of proteolysis and disorganization of the myofibrillar structure. CRC Crit Rev Food Sci Nutr 46:409-21.

Liu WR, Langer R, Klibanov AM. 1991. Moisture-induced aggregation of lyophilized proteins in the solid state. Biotechnol Bioeng 37:177-84.

Love RM. 1988. The food fishes: their intrinsic variation and practical implications. London: Farrand Press. 276 p.

Mommsen TP. 2004. Salmon spawning migration and muscle protein metabolism: the August Krogh principle at work. Comp Biochem Physiol 139B:383-400.

Nassour I, Leger CL. 1989. Deposition and mobilization of body fat during sexual maturation in female trout (Salmo gairdneri Richardson). Aquat Living Resour 2:153-9.

Ofstad R, Egelandsdal B, Kidman S, Myklebust R, Olsen RL, Hermansson A.-M. 1996. Liquid loss as affected by post-mortem ultrastructural changes in fish muscle; cod (Gadusmorhua L.) and salmon (Salmo salar). J Sci Food Agric 71:301-12.

Palti Y, Li JJ, Thorgaard GH. 1997. Improved efficiency of heat and pressure shocks for producing gynogenetic rainbow trout. Prog Fish-Cult 59:1-13.

Paredi ME, Crupkin M. 2007. Biochemical and physicochemical properties of actomyosin from pre- and post-spawned flounder (Paralichtyspatagonicus) stored on ice. LWT - Food Sci Technol 40:1716-22.

Penny I F. 1969. Protein denaturation and water-holding capacity in pork muscle. J Food Technol 4(3):269-73. 
Roura SI, Montecchia C, Goldemberg AL, Trucco R, Crupkin M. 1990. Biochemical and physicochemical properties of actomyosin from pre- and post-spawned hake (Merlucciushubbsi) stored on ice. J Food Sci 55(3):688-92.

Roura SI, Saavedra JP, Trucco RE, Crupkin M. 1992. Electron microscopical and biochemical studies of actomyosin from pre- and post-spawned hake. Comp Biochem Physiol 101B:361-5.

Salem M, Kenney PB, Rexroad CE, Yao J. 2006. Molecular characterization of muscle atrophy and proteolysis associated with spawning in rainbow trout. Comp Biochem Physiol $1 \mathrm{D}: 227-37$.

Salze G, Tocher DR, Roy WJ, Robertson DA. 2005. Egg quality determinants in cod (GadusmorhuaL.): egg performance and lipids in eggs from farmed and wild brood stock. Aquac Res 36:1488-99.

Sargent JR, Bell JG, McEvoy L, Trocher DR, Estevez A. 1999. Recent developments in the essential fatty acid nutrition of fish. Aquaculture 177:191-9.

SAS Institute Inc. 2004. SAS/STAT ${ }^{\circledR} 9.1$ user’s guide. 1st ed. NC: SAS Publishing. 5136 p.

Schubring R. 2008. Comparative study of the DSC pattern, color, texture and water-binding capacity of rainbow trout muscle during heating. J Food Process Press 32:190-218.

Srinivasan S, Xiong YL, Blanchad SP, Tidwell JH. 1998. Effects of freezing and thawing methods and storage time on physicochemical properties of freshwater prawns (Macrobrachiumrosenbergii). J Aqua Food Prod Technol 7:47-68.

Stabursvik E, Martens H. 1980. Thermal denaturation of proteins in post rigor muscle tissue as studied by differential scanning calorimetry. J Sci Food Agric 31:1034-42.

Taguchi T. 1970. Studies on the properties of fish actomyosin from fish muscle. V. Acitivation of fish actomyosin ATPase by lecithin. Bull Jap Soc Fish. 36:612-6.

Wang PA, Martinez I, Olsen RL. 2009. Myosin heavy chain degradation during post mortem storage of Atlantic cod (Gadus morhua L.). Food Chemistry 115:1228-33.

Wrolstad RE, Acree TE, Decker EA, Penner MH, Reid DS, Schwartz SJ, Shoemaker CF, Smith DM, Sporns P. 2004. Handbook of Food Analytical Chemistry. Hoboken: John Wiley \& Sons, Inc. 1392p.

Xiong YL. 1994. Myofibrillar protein from different muscle fiber type: Implications of biochemical and functional properties in meat processing. CRC Crit Rev Food Sci Nutr 34:293-320. 
Xiong YL. 2004. Chemical and physical characteristics of meat / Protein functionality. In: Jensen WK, editor. Encyclopedia of meat sciences. Elsevier Ltd. p 218-25.

Zhou P, Liu X, Labuza TP. 2008. Effects of moisture-induced whey protein aggregation on protein conformation, the state of water molecules, and the microstructure and texture of highprotein-containing matrix. J Agric Food Chem 56:4534-40. 


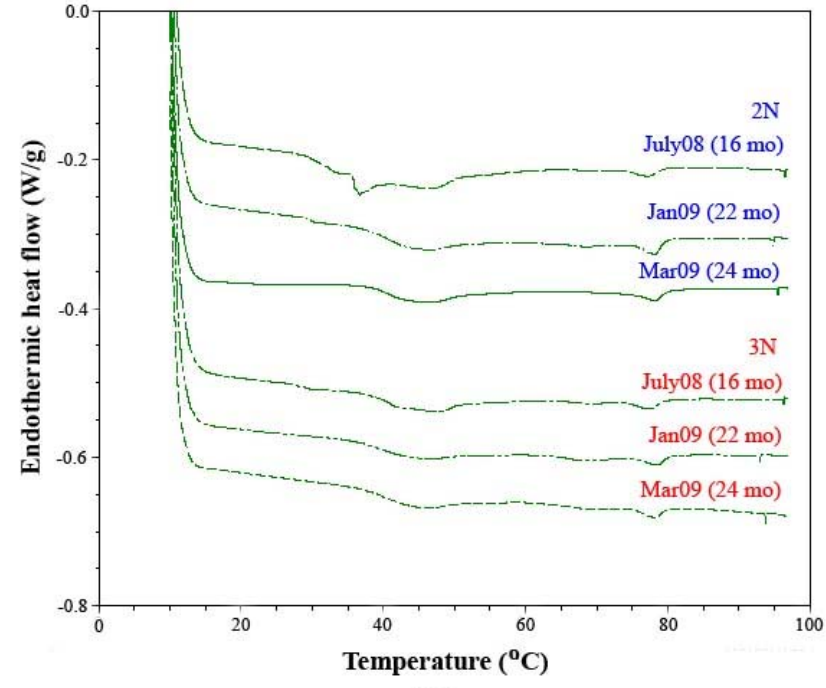

(a)

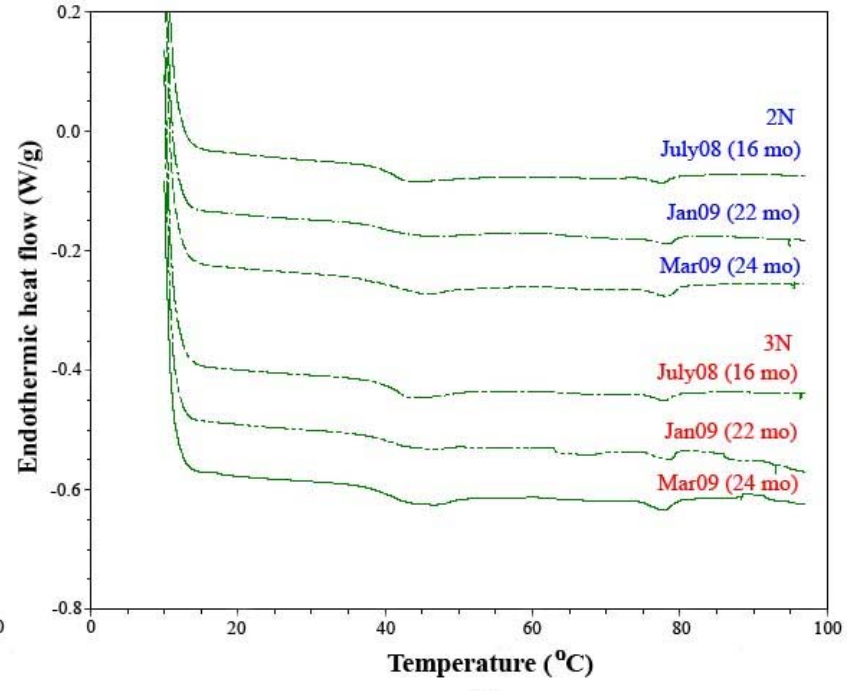

(b)

Figure 1 - DSC thermogram represents endothermic heat flow of whole muscle sample as a function of scanning temperature at heating rate of $10^{\circ} \mathrm{C} / \mathrm{min}$. Muscle samples were collected from diploid ( $2 \mathrm{~N}$; fertile) and triploid (3N; sterile) trout females of family 71 (a) and 70 (b) harvested in July 2008 and January and March 2009 when fish were at 16, 22, and 24 months of age, respectively. 
Table 1 - Onset melting temperature $\left(T_{m}\right)$, temperature at the maximum heat flow $\left(T_{\max }\right)$, and enthalpy of denaturation $(\Delta \mathrm{H})$ of whole muscle from diploid (2N; fertile) and triploid (3N; sterile) trout females harvested at three age endpoints. Two endothermic peaks were observed at two temperature ranges representing denaturation of myosin $\left(38-45{ }^{\circ} \mathrm{C}\right)$ and $\operatorname{actin}\left(77-79{ }^{\circ} \mathrm{C}\right)$.

\begin{tabular}{ccccccc}
\hline & \multicolumn{2}{c}{ July 08 (16mo) } & \multicolumn{2}{c}{ Jan 09 (22mo) } & \multicolumn{2}{c}{ Mar 09 (24mo) } \\
\cline { 2 - 6 } & $\mathbf{2 n}$ & $\mathbf{3 n}$ & $\mathbf{2 n}$ & $\mathbf{3 n}$ & $\mathbf{2 n}$ & $\mathbf{3 n}$ \\
\hline $\mathbf{T}_{\mathbf{m}}\left(\mathbf{C}^{\mathbf{0}} \mathbf{C}\right)$ & $36.61 \pm 5.18$ & $35.79 \pm 9.89$ & $33.88 \pm 4.76$ & $35.44 \pm 12.14$ & $38.58 \pm 2.49$ & $37.58 \pm 0.96$ \\
\hline $\mathbf{T}_{\mathbf{m a x}}\left({ }^{\mathbf{0}} \mathbf{C}\right)$ & & & & & \\
Myosin & $38.89 \pm 14.06$ & $44.27 \pm 1.62$ & $43.67 \pm 1.59$ & $44.06 \pm 0.44$ & $44.00 \pm 0.81$ & $44.08 \pm 3.23$ \\
Actin & $77.81 \pm 0.44^{\mathrm{b}}$ & $78.04 \pm 0.28^{\mathrm{b}}$ & $78.11 \pm 0.34^{\mathrm{b}}$ & $78.19 \pm 0.42^{\mathrm{b}}$ & $78.17 \pm 0.32^{\mathrm{b}}$ & $77.27 \pm 1.27^{\mathrm{a}}$ \\
\hline \multicolumn{1}{c}{$\mathbf{H}(\mathbf{J} / \mathbf{g})$} & & & & & & \\
Myosin & $1.02 \pm 0.68$ & $1.20 \pm 0.70$ & $0.82 \pm 0.30$ & $0.61 \pm 0.20$ & $1.64 \pm 1.24$ & $2.22 \pm 4.12$ \\
Actin & $0.20 \pm 0.07$ & $0.21 \pm 0.06$ & $0.30 \pm 0.10$ & $0.32 \pm 0.23$ & $0.17 \pm 0.11$ & $0.23 \pm 0.19$ \\
\hline
\end{tabular}

${ }^{a, b}$ Different superscripts of the same response denote significant differences $(P<0.05)$. Values are arithmetic mean \pm standard deviation of 10 fish. 


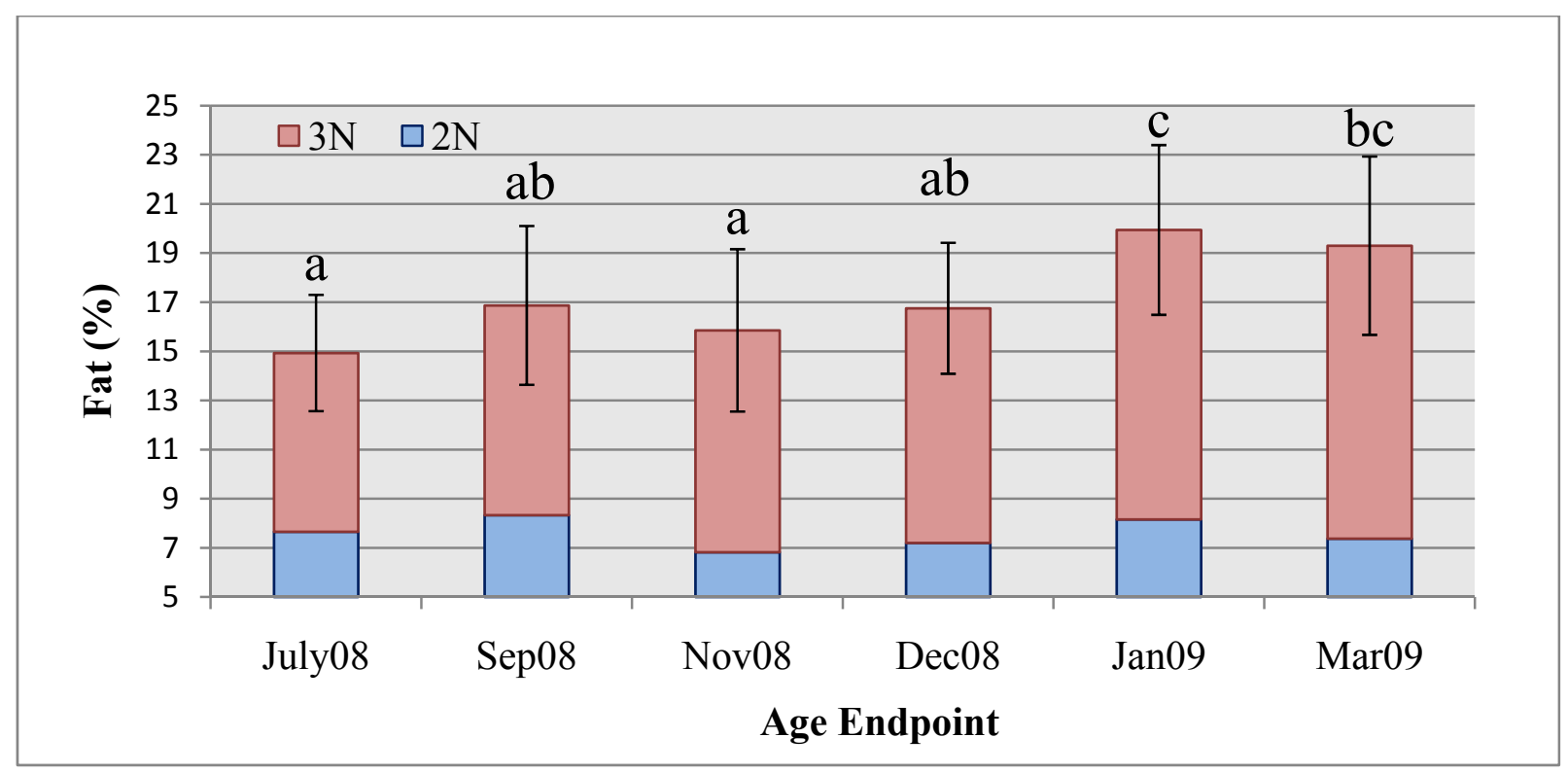

Figure 2 - Fat content (\%) of raw fillets from diploid (2N; fertile) and triploid (3N; sterile) trout females harvested at six age endpoints (July, September, November, and December 2008; January and March 2009) and from individuals of the family with a lower fat content $(6 \% \mathrm{v} .11 \%)$. Values are arithmetic mean averaged from 3 fish. Error bar represents standard deviation. ${ }^{\text {a-e }}$ Different letters are different $(P<0.05)$. 


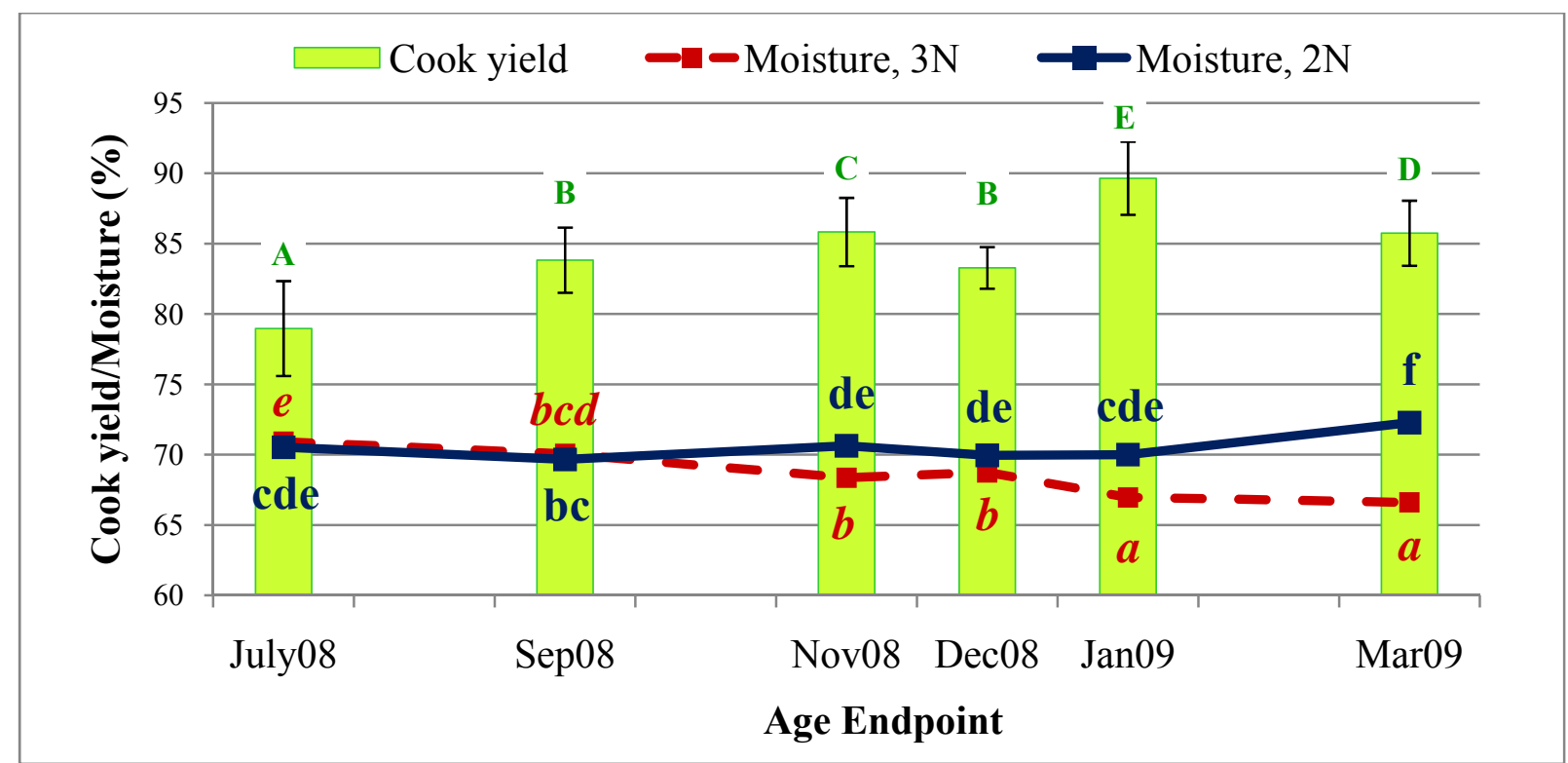

Figure 3 - Cook yield (\%) and moisture content (\%) of raw fillets at six age endpoints (July, September, November, and December 2008; January and March 2009). Values are arithmetic mean averaged from 20 fish for $\mathrm{CY}$ and 10 fish for moisture content. Error bar represents standard deviation. ${ }^{\text {a-f,A-E }}$ Different letters within the same response are different $(P<0.05)$. Mean comparison between ploidy (diploid; $2 \mathrm{~N}$ and triploid; $3 \mathrm{~N}$ ) was presented for moisture content. 


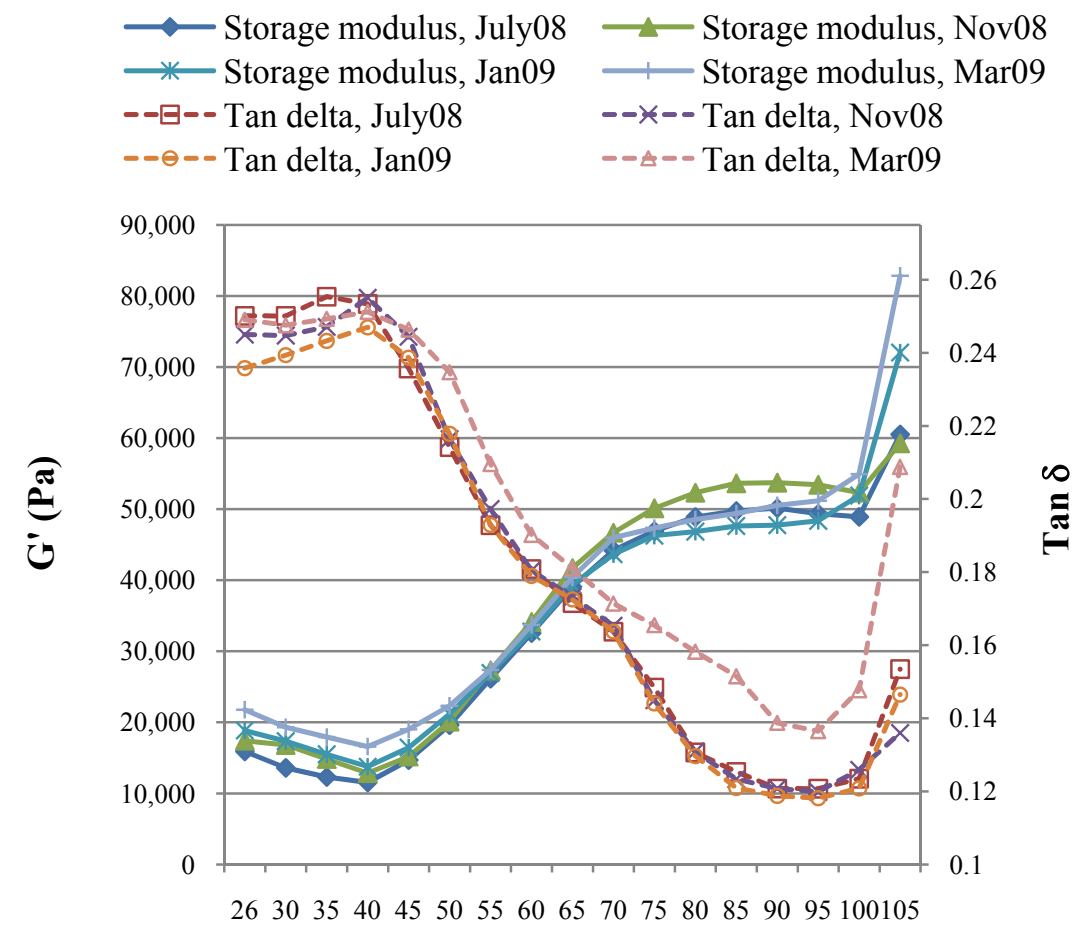

Temperature $\left({ }^{\circ} \mathrm{C}\right)$

Figure 4 - Change in storage modulus (G', Pa) and loss tangent $\left(\tan \delta=G^{\prime} ' / G^{\prime}\right)$ of muscle paste during thermal gelation. Muscle samples were collected from diploid (2N; fertile) trout females harvested at four age endpoints (July, November 2008 and January and March 2009) when fish were at 16, 20, 22, and 24 months of age, respectively. Values are average of 5 fish. 


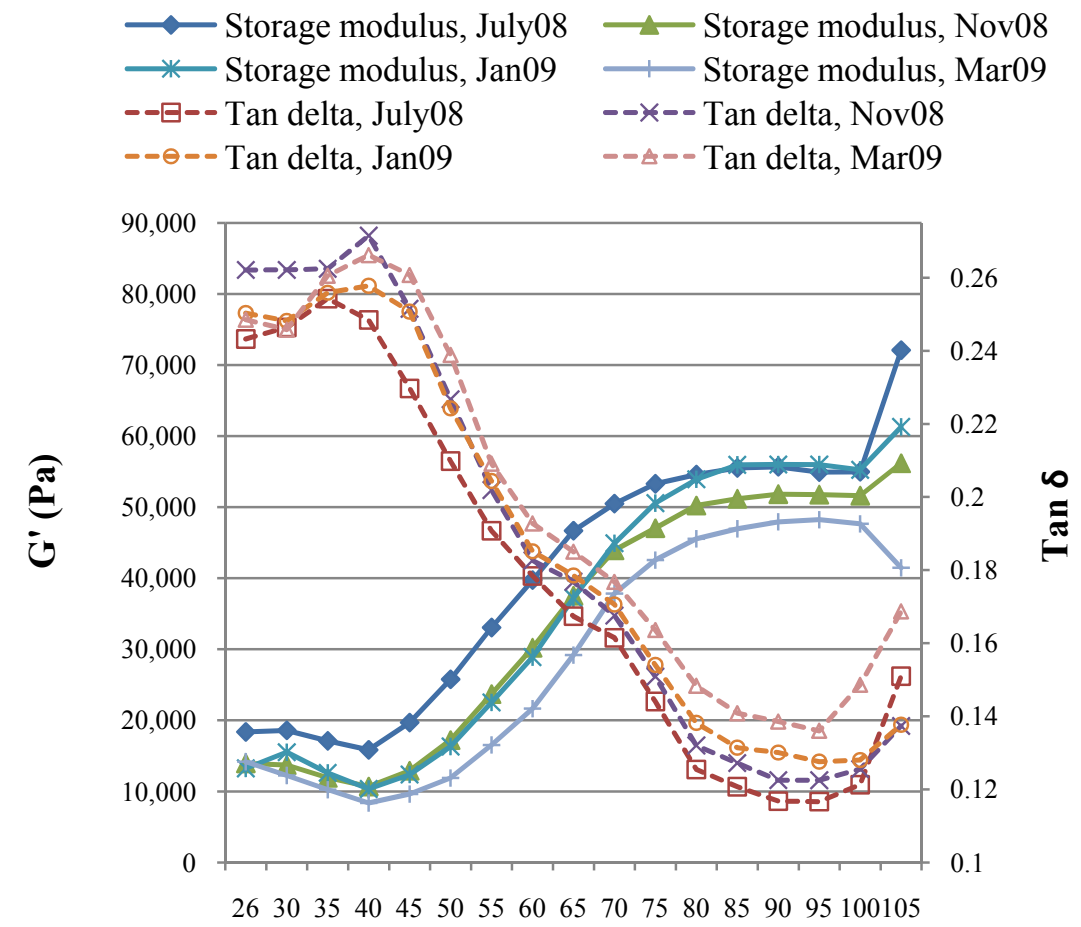

Temperature $\left({ }^{\circ} \mathrm{C}\right)$

Figure 5 - Change in storage modulus (G', Pa) and loss tangent $\left(\tan \delta=G^{\prime} ' / G^{\prime}\right)$ of muscle paste during thermal gelation. Muscle samples were collected from triploid (3N; sterile) trout females harvested at four age endpoints (July and November 2008 and January and March 2009) when fish were at 16, 20, 22, and 24 months of age, respectively. Values are average of 5 fish. 
Table 2 - Elastic modulus (G') and $\tan \delta\left(G^{\prime} / G^{\prime}\right)$ at selected range of temperature sweep for

muscle paste as affected by ploidy (diploid, 2N; triploid, 3N) and age endpoints (July and

November 2008; January and March 2009).

\begin{tabular}{|c|c|c|c|c|c|c|c|c|c|c|c|c|}
\hline \multirow{3}{*}{ Effect } & \multicolumn{12}{|c|}{ Temperature $\left({ }^{\circ} \mathrm{C}\right)$} \\
\hline & \multicolumn{2}{|c|}{35} & \multicolumn{2}{|c|}{40} & \multicolumn{2}{|c|}{45} & \multicolumn{2}{|c|}{50} & \multicolumn{2}{|c|}{60} & \multicolumn{2}{|c|}{80} \\
\hline & $\mathrm{G}^{\prime}$ & $\delta$ & $\mathrm{G}^{\prime}$ & $\delta$ & $\mathrm{G}^{\prime}$ & $\delta$ & $\mathrm{G}^{\prime}$ & $\delta$ & $\mathrm{G}^{\prime}$ & $\delta$ & $\mathrm{G}^{\prime}$ & $\delta$ \\
\hline July08 & $\begin{array}{c}14712 \\
(3.9 \mathrm{E}+03)\end{array}$ & $\begin{array}{c}0.255 \\
(5.6 \mathrm{E}-03)\end{array}$ & $\begin{array}{c}13687 \\
(3.8 \mathrm{E}+03)\end{array}$ & $\begin{array}{c}0.251 \\
(7.3 \mathrm{E}-03)\end{array}$ & $\begin{array}{c}17187 \\
(4.5 \mathrm{E}+03)\end{array}$ & $\begin{array}{c}0.233 \mathrm{a} \\
(5.0 \mathrm{E}-03)\end{array}$ & $\begin{array}{c}22694 \\
(5.8 \mathrm{E}+03)\end{array}$ & $\begin{array}{c}0.212 \mathrm{a} \\
(7.4 \mathrm{E}-03)\end{array}$ & $\begin{array}{c}36143 \\
(8.3 \mathrm{E}+03)\end{array}$ & $\begin{array}{c}0.180 \mathrm{a} \\
(7.7 \mathrm{E}-03)\end{array}$ & $\begin{array}{c}51730 \\
(7.4 \mathrm{E}+03)\end{array}$ & $\begin{array}{c}0.128 \mathrm{a} \\
(7.0 \mathrm{E}-03)\end{array}$ \\
\hline Nov08 & $\begin{array}{c}13373 \\
(4.6 \mathrm{E}+03)\end{array}$ & $\begin{array}{c}0.255 \\
(1.1 \mathrm{E}-02)\end{array}$ & $\begin{array}{c}11773 \\
(3.55 \mathrm{E}+03)\end{array}$ & $\begin{array}{c}0.263 \\
(1.8 \mathrm{E}-02)\end{array}$ & $\begin{array}{c}14056 \\
(3.2 \mathrm{E}+03)\end{array}$ & $\begin{array}{c}0.248 b \\
(1.6 \mathrm{E}-02)\end{array}$ & $\begin{array}{c}18664 \\
(3.7 \mathrm{E}+03)\end{array}$ & $\begin{array}{c}0.222 \mathrm{a} \\
(1.1 \mathrm{E}-02)\end{array}$ & $\begin{array}{c}32178 \\
(5.6 \mathrm{E}+03)\end{array}$ & $\begin{array}{c}0.182 \mathrm{a} \\
(4.6 \mathrm{E}-03)\end{array}$ & $\begin{array}{c}51271 \\
(8.0 \mathrm{E}+03)\end{array}$ & $\begin{array}{c}0.131 \mathrm{a} \\
(7.4 \mathrm{E}-03)\end{array}$ \\
\hline Jan09 & $\begin{array}{c}14055 \\
(7.4 \mathrm{E}+03)\end{array}$ & $\begin{array}{c}0.250 \\
(1.1 \mathrm{E}-02)\end{array}$ & $\begin{array}{c}12047 \\
(5.7 \mathrm{E}+03)\end{array}$ & $\begin{array}{c}0.252 \\
(8.0 \mathrm{E}-03)\end{array}$ & $\begin{array}{c}14410 \\
(5.9 \mathrm{E}+03)\end{array}$ & $\begin{array}{c}0.245 \mathrm{~b} \\
(6.1 \mathrm{E}-03)\end{array}$ & $\begin{array}{c}18747 \\
(7.3 \mathrm{E}+03)\end{array}$ & $\begin{array}{c}0.221 \mathrm{a} \\
(7.0 \mathrm{E}-03)\end{array}$ & $\begin{array}{c}30841 \\
(1.1 \mathrm{E}+04)\end{array}$ & $\begin{array}{c}0.182 \mathrm{a} \\
(5.5 \mathrm{E}-03)\end{array}$ & $\begin{array}{c}50377 \\
(1.2 \mathrm{E}+04)\end{array}$ & $\begin{array}{c}0.134 \mathrm{a} \\
(4.7 \mathrm{E}-03)\end{array}$ \\
\hline Mar09 & $\begin{array}{c}14087 \\
(7.2 \mathrm{E}+03)\end{array}$ & $\begin{array}{c}0.255 \\
(4.3 \mathrm{E}-03)\end{array}$ & $\begin{array}{c}12478 \\
(6.3 \mathrm{E}+03)\end{array}$ & $\begin{array}{c}0.259 \\
(3.9 \mathrm{E}-03)\end{array}$ & $\begin{array}{c}14321 \\
(6.6 \mathrm{E}+03)\end{array}$ & $\begin{array}{c}0.254 \mathrm{~b} \\
(1.5 \mathrm{E}-02)\end{array}$ & $\begin{array}{c}17109 \\
(8.5 \mathrm{E}+03)\end{array}$ & $\begin{array}{c}0.237 \mathrm{~b} \\
(2.8 \mathrm{E}-02)\end{array}$ & $\begin{array}{c}27684 \\
(1.3 \mathrm{E}+04)\end{array}$ & $\begin{array}{c}0.191 \mathrm{~b} \\
(1.3 \mathrm{E}-02)\end{array}$ & $\begin{array}{c}47039 \\
(1.8 \mathrm{E}+04)\end{array}$ & $\begin{array}{c}0.153 \mathrm{~b} \\
(1.5 \mathrm{E}-02)\end{array}$ \\
\hline P-value & NS & NS & NS & NS & NS & 0.0086 & NS & 0.0163 & NS & 0.0212 & NS & 0.0219 \\
\hline $2 \mathrm{~N}$ & $\begin{array}{c}15147 \\
(7.4 \mathrm{E}+03)\end{array}$ & $\begin{array}{c}0.249 \mathrm{a} \\
(9.5 \mathrm{E}-03)\end{array}$ & $\begin{array}{c}13685 \\
(6.3 \mathrm{E}+03)\end{array}$ & $\begin{array}{c}0.252 \mathrm{a} \\
(8.0 \mathrm{E}-03)\end{array}$ & $\begin{array}{c}16335 \\
(6.9 \mathrm{E}+03)\end{array}$ & $\begin{array}{c}0.241 \\
(7.0 \mathrm{E}-03)\end{array}$ & $\begin{array}{c}20809 \\
(8.8 \mathrm{E}+03)\end{array}$ & $\begin{array}{c}0.221 \\
(1.2 \mathrm{E}-02)\end{array}$ & $\begin{array}{c}33298 \\
(1.3 \mathrm{E}+04)\end{array}$ & $\begin{array}{c}0.183 \\
(7.9 \mathrm{E}-03)\end{array}$ & $\begin{array}{c}49143 \\
(1.4 \mathrm{E}+04)\end{array}$ & $\begin{array}{c}0.137 \\
(1.8 \mathrm{E}-02)\end{array}$ \\
\hline $3 \mathrm{~N}$ & $\begin{array}{c}12967 \\
(4.2 \mathrm{E}+03)\end{array}$ & $\begin{array}{c}0.258 \mathrm{~b} \\
(6.4 \mathrm{E}-03)\end{array}$ & $\begin{array}{c}11307 \\
(3.4 \mathrm{E}+03)\end{array}$ & $\begin{array}{c}0.261 \mathrm{~b} \\
(1.1 \mathrm{E}-02)\end{array}$ & $\begin{array}{c}13652 \\
(3.2 \mathrm{E}+03)\end{array}$ & $\begin{array}{c}0.248 \\
(1.4 \mathrm{E}-02)\end{array}$ & $\begin{array}{c}17799 \\
(3.9 \mathrm{E}+03)\end{array}$ & $\begin{array}{c}0.225 \\
(1.5 \mathrm{E}-02)\end{array}$ & $\begin{array}{c}30125 \\
(6.3 \mathrm{E}+03)\end{array}$ & $\begin{array}{c}0.185 \\
(7.5 \mathrm{E}-03)\end{array}$ & $\begin{array}{c}51066 \\
(9.2 \mathrm{E}+03)\end{array}$ & $\begin{array}{c}0.136 \\
(7.0 \mathrm{E}-03)\end{array}$ \\
\hline P-value & NS & 0.0032 & NS & 0.0232 & NS & NS & NS & NS & NS & NS & NS & NS \\
\hline
\end{tabular}

${ }^{a, b}$ Different letters of the same response denote significant differences $(P<0.05)$. Values are arithmetic

means(standard deviation) averaged from 5 fish. NS $=$ not significant. 


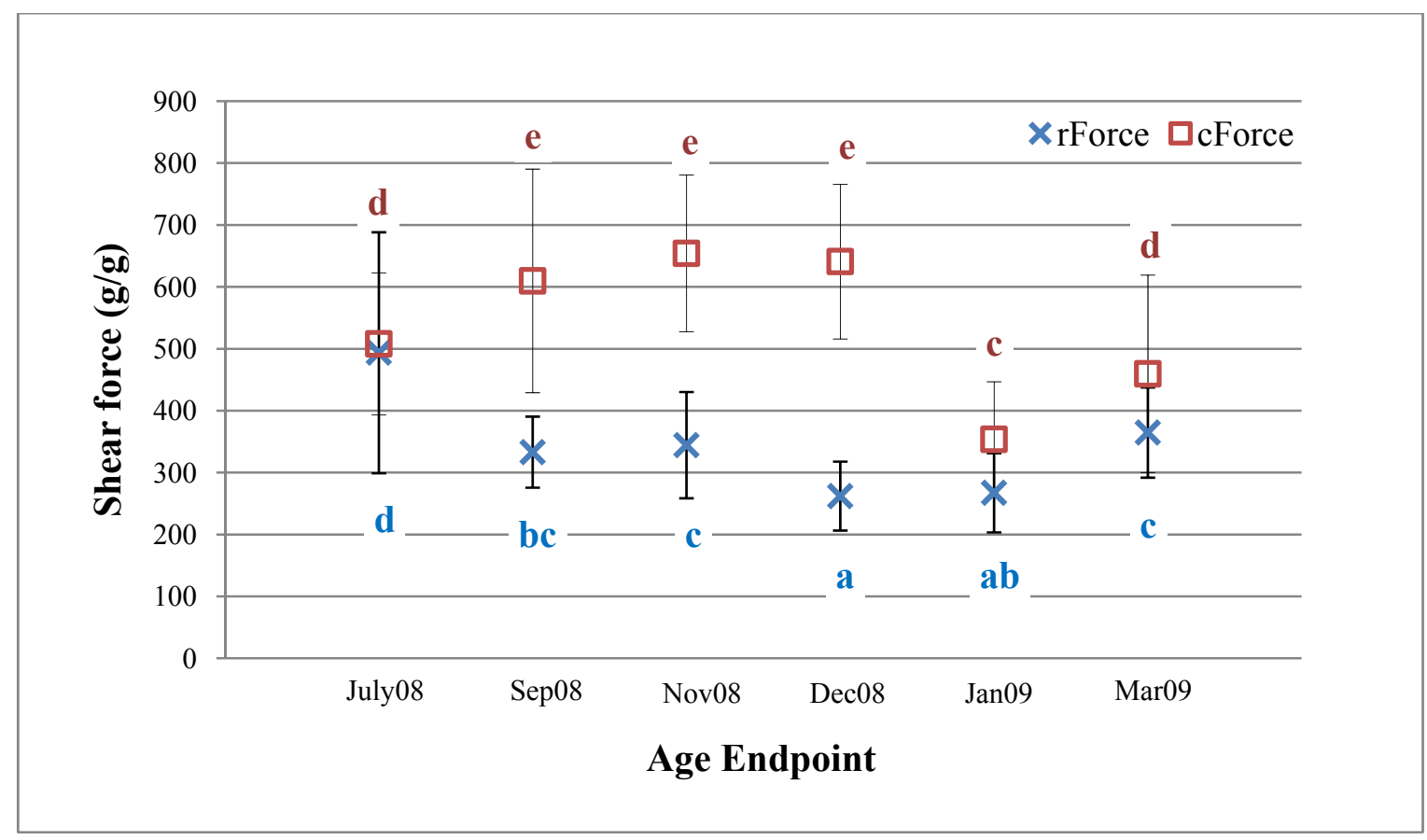

Figure 6 - Shear force (g/g) determined by Allo-Kramer shear attachment for raw (rForce) and cooked (cForce) fillet at six age endpoints (July, September, November, and December 2008; January and March 2009). Values are arithmetic mean averaged from 10 fish. Error bar represents standard deviation. ${ }^{\mathrm{a}-\mathrm{e}}$ Different letters are different $(P<0.05)$. 


\section{CHAPTER 4}

Comparison of Variable-Blade to Allo-Kramer Shear Method in Assessing Rainbow Trout (Oncorhynchus mykiss) Fillet Firmness 


\begin{abstract}
A new variable-blade (VB) was compared to an Allo-Kramer (AK) shear attachment in texture analysis of fillets from 1) a maturation study evaluating effects of age endpoint, ploidy, and cooking state and 2) a storage regimen study to describe effects of storage regimen and cooking state. In the maturation study, VB cooked texture was at minimum in January (22 mo; $P<0.0001$ ); shear force was $62.70 \mathrm{~g} / \mathrm{g}$ and energy of shear was $27,501 \mathrm{~g} * \mathrm{~mm}$. Fillet AK texture increased after cooking, and the softest cooked fillet was observed in January $(353.90 \mathrm{~g} / \mathrm{g})$. In March, alkaline-insoluble (a-i) hydroxyproline (HYP) of raw fillets had increased 4 fold compared to January (74.98 v. $17.25 \mu \mathrm{mole} / \mathrm{g}, P<0.05)$. A-i HYP correlated with AK shear force $(\mathrm{r}=0.57, P<0.0001)$ and energy of shear $(\mathrm{r}=0.47, P=0.0003)$ explaining 32 and $22 \%$ of the variability in these raw texture traits, respectively. In the storage regimen study, frozen storage at $-25{ }^{\circ} \mathrm{C}$ for 30 days beyond refrigerated storage (F30) decreased VB shear force $(P=0.0019)$ and AK energy of raw fillet shear $(P=0.0001)$ by 1.5 and 2 fold from those refrigerated for 3 (R3) and 7 (R7) days, respectively. Cooking increased VB and AK texture for all storage regimens $(P<0.05)$. Instrumental texture did not correlate with a-i HYP $(P>0.05)$ in the storage regimen study. The VB exhibited a comparable sensitivity to AK shear attachment in detecting variation in cooked texture and discriminating between raw and cooked texture.
\end{abstract}

Keywords: Rainbow trout, texture, sexual maturation, collagen. 


\section{INTRODUCTION}

An obstacle to using shearing device in aquatic food is associated with the low connective tissue content of fish fillets, the difference in hierarachial arrangement of connective tissue, and a lack of interconnecting cells in the longitudinal direction that make it vulnerable to shear and compression force (Hultin 1985). Absence of consistent terminology for shear responses results in poor correlation between instrumental and sensory methods (Bourne 1975) and incorrect interpretation of texture data (Voisey 1976). Sometimes 'shear' is used to describe any cutting action that causes the product to be divided into two pieces. Dunajski (1979) recommended that a shear test using thin blades is appropriate for the thin and short muscle fibers in fish. Aussanasuwannakul and others (2010) demonstrated that shear-cutting action imposed by the VB attachment is less-destructive and can predict sensory hardness $(\mathrm{r}=0.423)$ of trout fillets. Although the VB attachment resulted in lower shear value compared to AK, the VB attachment could reduce a substantial source of error due to bulk shearing or compression, and improve accuracy of the texture measurement. Since food texture is complex, involving multiparameter qualities (Guinard and Mazzucchelli 1996), it is important, in an instrumental test, that the investigator is aware of what physical parameter is measured. Variation in meat texture originates from inherent differences within the structure of raw meat/muscle tissue relating to contractile protein structures, connective tissue framework, lipid, and carbohydrate components, as well as external factors like cooking and sample handling (Solomon and others 2008).

Fish musculature is comprised of myotomes (flakes) which contain muscle cells that are

only one layer deep and connected to each other through heat-labile connective tissue of the myosepta. Collagen is a major protein of connective tissue, constituting $3-10 \%$ of the protein in 
fish muscle, and it plays a key role in maintaining fillet integrity (Sikorski and others 1984). Hydroxyproline and hydroxylysine contribute to the formation and stabilization of the collagen triple helix (Ramachandran 1988). During maturation, non-reducible, mature intermolecular cross-links between collagen fibers form (Bailey 2001). Collagen cross-links increase thermal stability of fish collagen (Ramachandran 1988). Hydroxylysylpyridinoline (PYD) cross-links maintain the physical structure and rigidity of the collagen matrix (Bailey 1998) and positively correlate with texture of raw and smoked Atlantic salmon (Salmosalar L.) flesh (Li and others 2005; Johnston and others 2006) and texture of Atlantic halibut flesh (Hagen and others 2006). Starvation increases collagen cross-links (Love and others 1976; Gomez Guillen and others 2000; Bugeon and others 2004) and fillet firmness (Austreng and Krogdahl 1987). An increase in HYP insolubility reflects an increase in PYD concentration (Haugen and others 2006).

A less destructive approach, using the VB shear-cutting method, was designed to overcome the limitation of 1) weak correlations between instrumental and sensory texture measurements and 2) insensitivity in determining contribution of collagen and myofibrillar proteins to fillet texture. This experiment was conducted to relate instrumental texture to quality and quantity of the connective tissue protein, collagen. Fillet hydroxyproline (HYP) solubility (quality) and concentration (quantity) were considered from two separate experiments that investigated the effect of 1) sexual maturation and 2) storage regimen on fillet texture. In the maturation study, treatment effects included age, ploidy, cooking state, and their interactions. In the storage regimen study, treatment effects included storage regimen, cooking state, and their interaction. $\mathrm{VB}$ was compared to $\mathrm{AK}$ in terms of 1) sensitivity in discriminating texture variation and 2) predictability in relating texture parameters to HYP content. To determine predictability, we related shear force and area under force-deformation curves to alkaline- 
soluble, insoluble, and total HYP content of the fillet. For comparison to the AK, multiblade method, a VB attachment was designed with two key features for measuring fish texture. First, a thin blade (0.635-mm thick) allows shearing of muscle fibers without destroying fillet structure compared to thicker AK blades (3.0-mm thick). Second, twelve, 12.7 x $25.4 \mathrm{~mm}$ blades, arranged in two rows on the attachment, allow an incision width and depth that captures a wide range of texture variation within the fillet sample. 


\section{MATERIALS AND METHODS}

\section{Sample preparation}

Maturation Study. Rainbow trout females (Oncorhynchus mykiss) were raised and maintained at the National Center for Cool and Cold Water Aquaculture (NCCCWA; United States Department of Agriculture, Agricultural Research Service) in Leetown, West Virginia. Details egg and sperm collection, triploid induction, and fish care are described by Aussanasuwannakul and others (2011). Five fish from each of 2 family by 2 ploidy (2N, fertile; and $3 \mathrm{~N}$, sterile) combinations ( 5 fish $\times 4$ combinations $=20$ fish) were sampled at three age endpoints (December 2008 and January and March 2009). These three sampling points marked age endpoints of 21,22 , and 24 months post hatching. Within these three months, body weight ranged from 2695 to $3221 \mathrm{~g}$ for $2 \mathrm{~N}$ and from 2254 to $3056 \mathrm{~g}$ for $3 \mathrm{~N}$ females. Fish were held off feed 24 hours prior to sampling and were anesthetized using tricaine-S at the NCCCWA; no portion of these fish was consumed. Fish were stored on ice for $3.5 \mathrm{hr}$ for delivery to Morgantown, WV. Fish were subsequently packed on ice and filleted the following day or approximately 18 hours after harvest. Fish care and experimentation followed the guidelines outlined by USDA and the NCCCWA Animal Care and Use Committee, which are in line with the National Research Council publication Guide for Care and Use of Laboratory Animals.

Storage Study. Seventy-two fish $(1149 \pm 234 \mathrm{~g})$ were harvested at the Conservation Fund's Freshwater Institute, Sheperdstown, WV. Fish were mechanically stunned and stored on ice for delivery to Morgantown, WV, an approximate 3.5-hour trip. Fish were eviscerated and filleted within 4 hours after harvest. Approximately $18 \mathrm{~h}$ later, these fillets were placed on Styrofoam trays and overwrapped with polyvinyl chloride (PVC) film; they were stored 
according to assigned storage treatment. Eighteen fish were assigned to each of 4 storage regimens. Two storage regimens consisted of refrigeration at $2{ }^{\circ} \mathrm{C}$ for three days (R3) and refrigeration at $2{ }^{\circ} \mathrm{C}$ for seven days (R7). Two additional regimens were vacuum-packaged and frozen at $-25{ }^{\circ} \mathrm{C}$ for thirty days after three days (R3F30) or seven (R7F30) days of refrigerated storage (Aussanasuwannakul and others 2010).

Each fillet half was cut into cranial and caudal portions. Using the lateral line as a reference, each portion was used to remove $40 \times 80 \mathrm{~mm}$ sections consisting of approximately the same amount of dorsal and ventral muscle. Section location (cranial or caudal half) was randomly assigned to raw or cooked instrumental evaluation. For cooked evaluation, fillet sections were thermally processed in a microprocessor-controlled smoke oven (Model CVU-490; Enviro-Pak, Clackamas, OR, U.S.A.) set at $82^{\circ} \mathrm{C}$, and the cooking process was stopped when the internal fillet temperature reached $65.5^{\circ} \mathrm{C}$. This cooking temperature was selected according to the USDA recommended minimum internal temperature for fish to achieve a safe temperature without overcooking (Food Safety Education 2010). Cooking time was approximately 45 minutes.

\section{Instrumental texture analyses}

Texture measurement of raw and cooked fillet sections was performed at room temperature $\left(25^{\circ} \mathrm{C}\right)$ using a variable 12-blade (VB) and a 5-blade, Allo-Kramer (AK) shear attachment mounted to the TA-HDi ${ }^{\circledR}$ Texture Analyzer (Texture Technologies Corp., Scarsdale, NY, U.S.A.), equipped with a 50-kg load cell, at a crosshead speed of $127 \mathrm{~mm} / \mathrm{min}$. Muscle sections were sheared perpendicular to muscle fiber orientation. Force-distance graphs were recorded and analyzed using the Texture Expert Exceed software (version 2.60; Stable Micro 
Systems Ltd., Surrey, U.K.). Parameters, determined from the graph included 1) maximum shear force ( $\mathrm{g} / \mathrm{g}$ sample) and 2) area under the curve $(\mathrm{g} * \mathrm{~mm})$ from $0 \mathrm{~g}$ force to maximum force. The remainings after section removal were pulverized with liquid nitrogen in a stainless steel, Waring Blender (Waring, New Hartford, CT, U.S.A.) and kept at $-25^{\circ} \mathrm{C}$ for hydroxyproline (HYP) analyses. In variable-blade shear evaluations, a fillet section was placed on a flat base (plastic cutting board). The fillet was adjusted in the blade holder frame $(30 \times 80 \mathrm{~mm})$ so that the cutting area aligned consistently with the sample surface area. Blade orientation was changed to provide perpendicular orientation to the muscle fibers. Test settings and acquired responses were the same as Allo-Kramer evaluations, except the attachment was programmed to return to the original distance before the blade touched the base. Depth of penetration was standardized; average $(\mathrm{N}=48)$ blade penetration into raw and cooked fillets was $20.7 \pm 2.7$ and $20.9 \pm 2.5 \mathrm{~mm}$, respectively. Five-blade, Allo-Kramer evaluations consisted of five blades passing through the fillet section and through the slotted plate that is part of the sample holder. After testing, the AK attachment returned to the starting point. Key features of VB and AK attachments and testing conditions are provided in Table 1.

\section{Determination of fillet hydroxyproline content}

Hydroxyproline content was determined following the method of Li and others (2005). Sodium hydroxide $(0.2 \mathrm{M})$ was used to separate hydroxyproline into alkaline soluble and insoluble fractions. A $2-\mu \mathrm{L}$ aliquot of hydrolysate was mixed with $200 \mu \mathrm{L}$ of water and dried in an Eppendorf tube using a centrifugal vacuum concentrator Eppendorf $^{\circledR}$ 5301, Cole-Parmer, IL,

U.S.A.). This dried sample was resuspended in $200 \mu \mathrm{L}$ of $0.1 \mathrm{M}$ boric buffer, $\mathrm{pH} 11.4$, 
containing $11.2 \mu \mathrm{M}$ homoarginine as an internal standard. The fluorenylmethoxycarbonyl (FMOC) derivatized amino acids were separated using a ternary gradient described by Bank and others (1996). The eluate was monitored for fluorescence at $\lambda_{\mathrm{ex}}=254 \mathrm{~nm}$ and $\lambda_{\mathrm{em}}=630 \mathrm{~nm}$. The Varian Star Chromatograph Workstation software (version 6; Varian Inc., CA, U.S.A.) was used to identify and quantify homoarginine and hydroxyproline peaks. Sample hydroxyproline concentration was quantified based on the relative signal areas of sample and internal standard (Harris 2007).

\section{Experimental Design and Statistical Analysis}

The "Maturation Study" was conducted in the context of a $2 \times 3 \times 2$ randomized complete block design with a fixed block effect (family). Treatment effects included three levels of age endpoint (December, 2008; and January and March, 2009) and two ploidy conditions (diploid, 2N; and triploid, 3N). Five fish were randomly assigned to each of four treatment combinations (2 ploidies $\times 2$ families) at each age endpoint. Therefore, each treatment combination was repeated five times on randomly selected fish (Aussanasuwannakul and others 2011). The "Storage Regimen Study" was conducted in the context of a 4x2 completely randomized design. Treatment effects were storage regimen (R3, R7, R3F30, and R7F30) and cooking state (raw and cooked, Aussanasuwannakul and others 2010). For both studies, treatment effects and their interaction on HYP concentration and instrumental texture were determined. Data were analyzed by analysis of variance (ANOVA) using the Mixed Model (MIXED) procedure of SAS $^{\circledR}$ system for Windows, version 9.1 (SAS Institute Inc 2004). Relationships among independent variables were analyzed by Pearson product-moment correlation and linear 
regression analysis using CORR and REG procedures of SAS ${ }^{\circledR}$ system for Windows, version 9.1 (SAS Institute Inc 2004), respectively. Significance was defined at $P<0.05$. The predictive relationships between a-i HYP content and raw instrumental measurement were determined by polynomial regression analysis in a stepwise fashion; P-value and the square of the multiple correlation coefficient $\left(\mathrm{R}^{2}\right)$ were criteria used for selecting the best-fit model (Dowdy and others 2004). 


\section{RESULTS AND DISCUSSION}

\section{Separating texture differences}

Maturation study. VB detected effect of age endpoint on shear force and energy of shear of cooked fillets $(P<0.0001$; Table 2). Because VB texture data on raw fillets was not available, we could not evaluate the sensitivity of VB in detecting effect of age endpoint*cooking state on fillet texture. Using VB, firmness of cooked fillets was highest $(\mathrm{P}<0.05)$ in December $(21 \mathrm{mo})$ followed by March $(24 \mathrm{mo})$, and January $(22 \mathrm{mo})$. AK detected effect of age endpoint*cooking state on shear force and energy of shear $(P<0.0001$; Table 2$)$. Regardless of ploidy, AK showed that raw fillets were firmest at spawning in March $(364.72 \mathrm{~g} / \mathrm{g})$ compared to December and January $(264.84 \mathrm{~g} / \mathrm{g})$. AK showed that fillet firmness increased after cooking; the softest cooked fillet among the three endpoints was observed in Jan (353.90 g/g). Alkaline-insoluble (a-i) hydroxyproline (HYP) concentration was similar for $2 \mathrm{~N}$ and $3 \mathrm{~N}$ muscle through January but increased 2 and 4 fold for $3 \mathrm{~N}$ and $2 \mathrm{~N}$ muscle, respectively, by March. In March, a-i HYP of raw fillet increased by 4 fold from Jan $(\mathrm{P}<0.05$; Table 2$)$. A-i HYP positively correlated with energy of shear $(\mathrm{r}=0.41, P=0.0007)$. Cooking increased a-s HYP and total HYP (age endpoint*cooking state; $P<0.05$ ) in January and March, and decreased a-i HYP (age endpoint*cooking state; $P<0.05$ ) in March (Table 2). The increase in total HYP when cooked was likely associated with a "concentrating" effect caused by water and fat loss during cooking. In addition, cooking would have denatured (hydrolyzed) some collagen; increasing a-i HYP. Variation in muscle cellularity and associated changes in connective tissue matrix are important determinants of texture (Montero and Borderías, 1990; Johnston, 1999; Hagen and others 2007). Season was a dominant factor explaining variation in flesh quality of triploid and diploid Atlantic 
salmon (BjØrnevik and others 2004). Diploid muscle fibers had a smaller cross-sectional area and higher fiber density than those of triploid animals (O'Keefe and Benfey 1999). Nutritional restriction (30-day starvation) increased fillet firmness in Atlantic salmon, whereas there was no effect of ploidy on texture (Sigurgisladottir and others 2001). In the present study, there was no difference in instrumental texture between the two ploidies at any age endpoint $(P>0.05)$. Espe and others (2004) reported that collagen composition changes with season and that ruptures of the collagen matrix cause gaping. Collagen insolubilization was observed in salmon muscle after 30-days starvation (Gomez-Guillen and others 2000).

Alkaline-insoluble collagen is enriched with reducible and mature collagen cross-links, and these changes are related to an increase in fillet firmness ( $\mathrm{Li}$ and others 2005). Therefore, increased collagen insolubility could be translated into an increase in collagen cross-links that strengthen the perimyseal connective tissue network. An increased a-i HYP content in March might be indicative of a strengthened connective tissue network that wraps around muscle fiber bundles and contributes to their resistance to shear.

Storage regimen study. VB detected an effect of storage regimen*cooking state on shear force $(P=0.0019)$, whereas AK detected an effect of storage regimen*cooking state on energy of shear ( $P=0.0001$; Table 3). In the storage regimen study, frozen storage at $-25^{\circ} \mathrm{C}$ for 30 days $(\mathrm{F} 30)$ decreased VB shear force $(P=0.0019)$ and AK energy of shear $(P=0.0001)$ of raw fillets by 1.5 and 2 fold, respectively, compared to those receiving 3-day (R3) and 7-day refrigeration (R7) treatments. Cooking increased VB shear force and AK energy of shear at all levels of storage regimen $(\mathrm{P}<0.05)$ due to increased protein-protein interactions and concomitant decreases in protein-water and protein-lipid interactions. Cooking concentrated soluble HYP (cooking state effect; $P=0.0198)$ and total HYP $(P=0.0223)$; a-s HYP and total HYP content 
increased by 1.4 fold after cooking. There was no effect of cooking state on a-i HYP content $(P>0.05)$.

There is no general agreement about the exact mechanisms involved in the texture changes observed during ice storage of fish (Nollet and others 2007). Fish muscle generally becomes softer during chilled storage (Sato and others 1991; Ando and others 1992a, b). During storage in ice, some myofibrillar proteins degrade; however, no changes had been observed in the structure of the contractile elements (Verrez-Bagnis 1997; Busconi and others 1989). Ando and others (1992b) found that differences in firmness among three fish species was related to density and arrangement of collagen fibrils in the connective tissue. Softening of rainbow trout postmortem is caused by a disintegration of collagen fibers (Ando and others 1992a, b). During frozen storage, myofibrillar proteins and collagens aggregate, inducing a toughening of the muscle (Montero and Borderías 1990, 1992). The sarcoplasmic reticulum degrades and then appears to act like cement to hold the individual myofibrils together (Howgate 1977). Disintegration of collagen fibrils and cleavage of cross-links are responsible for a decrease in firmness of frozen stored fillets (Ando and others 1992b, 1993; Bremner 1992; Ando and others 1999). Storage regimen did not affect HYP content $(P>0.05)$ probably because other sources of variation were more important. The VB attachment was able to detect variation in texture of cooked fillets and discriminate between raw and cooked texture.

\section{Relating instrumental texture to HYP analysis}

Maturation study. A-i HYP correlated with AK shear force ( $r=0.57, \mathrm{P}<0.0001$; Table 4) and energy of shear ( $r=0.47, P=0.0003$; Table 4$)$. In addition, the first-order linear regression 
was the best-fit model for describing contribution of a-i HYP to changes in raw fillet texture. A-i HYP explained 32\% of the variability in AK shear force (Figure 1) and 22\% of the variability in AK energy of shear (Figure 2). VB texture of cooked fillets did not correlate with HYP concentration possibly because cooking hydrolyzes some collagen and diminishes its contribution to texture. Perhaps, due to greater sample involvement, AK provided a better overall evaluation of texture through assessment of the myofibrillar component. We found that fat content negatively correlated with $\mathrm{AK}$ shear force $(\mathrm{r}=-0.35, P=0.0005)$, explaining $12 \%$ of the total variation (Aussanasuwannakul and others 2011). We did not determine VB texture in raw fillet; therefore, correlation between VB texture and fat content could not be determined.

Storage regimen study. In this study, instrumental texture did not correlate with any HYP fraction $(\mathrm{P}>0.05)$. However, we found that VB shear force correlated with sensory hardness $(\mathrm{r}=0.423, \mathrm{P}=0.0394)$ and cook loss $(\mathrm{r}=0.412, \mathrm{P}=0.0450$, Aussanasuwannakul and others 2011). Taylor and others (2002) demonstrated that distinct structural changes in ice-stored fillets, up to 14 days, were associated with breaks in myofiber-to-myofiber attachments, and later with breaks in myofiber-to-myocommata (myofiber-to-myosepta) attachments. Limited variation in instrumental texture and fillet composition existed for fish in this data set; these fish were collected at the same age. Consequently, this lack of variation limited our ability to show a relationship between instrumental texture and HYP content contrary to the findings of Shigemura and others (2003). They reported a correlation between type $\mathrm{V}$ collagen and post-mortem softening, measured as maximum force using 3-mm cylindrical plunger, of fish meat during chilled storage $(\mathrm{r}=0-89, P<0.05)$.

According to Hyldig and Nielsen (2007), fish muscle cells are very short $(\leq 1 \mathrm{~cm}$ in large species) and they contain, primarily, connective tissues of the myocommata and acotmyosin; 
these proteins have very different effects on overall texture. A contribution of collagen to texture variation was seen in the maturation study and was detected by $\mathrm{AK}$; whereas, results from the storage regimen study suggested a contribution of myofibrillar protein and composition to fillet texture. With heating, collagen shrinks then softens; whereas, the actomyosin complex changes from a soft gel to a firmer denatured complex (Dunajski 1979) as protein-protein interactions increase. Consequently, the contribution of these fillet proteins to texture or their relative effect on fracture mechanism changes following cooking. Therefore, it very difficult to relate textural attributes of raw fillets to attributes following cooking. MØrk Øre and Einen (2003) found that sensory hardness of smoked salmon was better predicted when the instrumental analysis was performed on raw rather than on cold-smoked salmon. Studies of raw meat texture are not instructive because raw meat rheology cannot be related to connective tissue content to the final cooking temperature (Taylor 2004). In meat and when tenderness differences are due to intrinsic determinants (i.e., concentration of connective tissue, cross-linking, and intramuscular fat, etc.) that have similar effects on cooked and raw meat, measures of tenderness on raw meat will be particularly useful (Purchas 2004). In addition to cooking state, choice of instrumental method and test parameters determines how well instrumental muscle texture relates to intrinsic determinants. Ashton and others (2010) found that Warner-Bratzler shear data best predict texture of smoked salmon flesh $(\mathrm{r}=0.811, P<0.001)$ compared to data from tensile tests and texture profile analyses (TPA), using a flat-ended cylinder.

According to Dobraszczyk and Vincent (1999), maximum force and area represent different mechanical properties. Maximum force is the maximum stress an object will withstand before it breaks and reflects strength of the muscle. On the other hand, area under the forcedeformation curve is the energy required to propagate a fracture by a given crack area and 
reflects toughness or extensibility of muscle (Dobraszczyk and Vincent 1999). In our storage regimen study, AK area detected effect of F30 treatment and cooking state; whereas, VB detected variation in fillet texture only after cooking. This method discrepancy is likely associated with the different responses to heat for connective tissue and myofibrillar components and is reflected as different responses measured by each method. In the maturation study, the insignificance of ploidy's effect on texture and a-i HYP content suggested an influence of muscle fat on sensitivity of the shear attachment to detect texture variation. Fillets with a high fat content (3.4-7.3\% wet weight) were described as juicier than fillets with a low fat content (2.94.6\% wet weight; Nortvedt and Tuene 1998). The intramuscular lipid fraction, through its rheological properties and its dilution of the collagen network in particular, has improved tenderness of meat from terrestrial animals (Koch and others 1989). Li and others (2005) showed that fast muscle fibers of salmon are covered with a continuous sheet of connective tissue and lipid droplets, particularly in the region of the myosepta. Therefore, it is possible that muscle fat $(8-10 \%)$ offsets connective tissue's effect on texture by its quantity and spatial arrangement in muscle structure.

\section{Possible use of VB shear-cutting method in fillet texture analysis}

The term "shear" implies that stresses are applied parallel to the direction of force and in the same plane as deformation (Voisey 1976); in "cutting-shear failure", cutting action causes the product to be divided into two pieces (Bourne, 2002). Clarifying the term "shear" reduces confusion regarding the deformation mechanism and therefore improves the accuracy of texture

data interpretation. Using AK, deformation involves compression force that causes slippage of 
myotomes and includes contributions from various sources to overall texture. The maturation study showed that muscle fat content is a key contributor to texture variation, and this study demonstrated a potential use of the AK shear attachment in characterizing this variation. Furthermore it suggests that compression mechanics may be necessary to describe deformation and thus variation in fillet texture. Robb and others (2002) reported that lipid content affected sensory perception of softness; however, this trend was not found when using a flat-ended probe and a texture analyzer (Young and others 2005). Similar to the present storage regimen study, Veland and Torrissen (1999) compared the ability of the compression, and Warner-Brazler shear tests to differentiate between recently killed salmon and salmon stored on ice for up to 24 days; they concluded that the shear test is perhaps more appropriate as an imitation of mastication because it applies large deformation with semi-sharp edges.

Hamann (1988) indicated that instrumental texture measurement reflects gel cohesiveness and basic muscle functionality, and therefore, sensory texture. However, any deformability test that changes the shape of the test specimen and does not compensate for this mathematically is less than ideal for obtaining this information (Hamann 1988). A shear test is less effective than TPA in terms of imitating mastication. The shear test could not describe muscle elasticity because shear tests apply only one deformation to the sample and thus gives no measure of how much of the applied work is absorbed as elastic deformation, or the work required in successive chewing (Veland and Torrissen 1999). Shear action using a sharpened blade was able to demonstrate effect of muscle location; the Warner-Bratzler method has a greater sensitivity over an unsharpened knife blade and over a cylinder method in discriminating fillet firmness from head to tail (Ashton and others 2010). In addition, these authors stated that differences in 
collagen concentration in salmon muscle could be detected by a shear method using cutting probes that pass directly through any connective tissue in their path.

Because cooking makes fish muscle myotomes separate easily and thereby affects sample fragility, less-destructive analysis is the best approach to determine texture of a cooked fillet. While shear tests using rounded blades encompass tensile and compression stresses as well as shear stresses, the thin blade of the VB attachment appears to be affected less by compression and tensile forces. The VB blade cut completely through muscle fibers and, in cooked fillets, it was able to pass through the surface skin (pellicle) and muscle bundle. Consequently, this texture measurement appears to exclude tensile and compression components and improves correlation with sensory texture (Aussanasuwannakul and others 2010). In addition, comparing VB to AK texture will allow us to determine whether shear action needs a compression component. We found that the VB was able to discriminate between raw and cooked texture; however, VB texture could not be related to variation in muscle composition. VB is potentially the best approach to determine contributions of muscle fiber proteins and to relate cooked to raw texture. In the maturation and storage regimen studies, VB did not to demonstrate its predictability in relating texture to HYP content. Perhaps this limitation was associated with the narrow range of variation in this studies and muscle fat which is unique to these sets of fish. Future research needs to address effect of fat on VB texture and relate VB texture to muscle fiber number and diameter. Finally, since fish collagen content is low and because fish collagen is less thermally stable, relating VB texture to myofibrillar protein is an alternative to improving the predictability of cooked fillet from raw fillet texture. 


\section{CONCLUSION}

VB and AK detected variation in texture of sexually mature and refrigerated and frozen

fish. AK attachment could relate collagen content to the texture of sexually mature fish. VB was less-destructive and could discriminate between raw and cooked texture. 


\section{REFERENCES}

Ando M, Toyohara H, Sakaguchi M. 1992a. Three-dimensional structure of collagen fibrillar network of pericellular connective tissue in association with firmness of fish muscle. Nippon Suisan Gakkaishi 58:1361-4.

Ando M, Toyohara H, Sakaguchi M. 1992b. Post-mortem tenderization of rainbow trout muscle caused by disintegration of collagen fibers in the pericellular connective tissue. Bull Jpn Soc Sci Fish 58:567-70.

Ando M, Toyohara H, Shimizu and Y, Sakaguchi M. 1993. Post-mortem tenderization of fish muscle due to weakening of pericellular connective tissue. Nippon Suisan Gakkaishi 59:1073-6.

Ando M, Nishiyabu A, Tsukamasa Y, Makinodan Y. 1999. Post-mortem softening of fish muscle during chilled storage as affected by bleeding. J Food Sci 64:423-8.

Ashton T J, Michie I, Johnston IA. 2010. A novel tensile test method to assess texture and gaping in salmon fillets. J Food Sci_75(4):S182-90.

Aussanasuwannakul A, Kenney PB, Brannan RG, Slider SD, Salem M, Yao J. 2010. Relating instrumental texture, determined by variable-blade and Allo-Kramer shear attachments, to sensory analysis of rainbow trout, Oncorhynchusmykiss, fillets. J Food Sci 75(7):S36574.

Aussanasuwannakul A, Kenney PB, Weber GM, Yao J, Slider SD, Salem M. 2011. Effect of sexual maturation on growth, fillet composition, and texture of rainbow trout (Oncorhynchus mykiss) on a high nutritional plane. Aquaculture. Available from: doi: 10.1016/j.aquaculture.2011.04.015. Accessed May 2, 2011.

Austreng E, Krogdahl Å. 1987. Food quality of cultured salmonids can be influenced. Feedstuffs 31:12-13.

Bailey AJ, Paul RG, Knott L. 1998. Mechanisms of maturation and ageing of collagen. Mech Ageing Dev 106:1-56.

Bailey AJ. 2001. Molecular mechanisms of ageing in connective tissues. Mech Ageing Dev 122:735-55.

Bank RA, Jansen EJ, Beekman B, te Koppele JM. 1996. Amino acid analysis by reverse-phase high-performance liquid chromatography: improved derivatization and detection conditions with 9-fluorenylmethyl chloroformate. Analytical biochemistry 240:167-76. 
Bjørnevik M, Espe M, Beattie B, Nortvedt R, Kiessling A. 2004. Temporal variation in muscle fibre area, gaping, texture, colour and collagen in triploid and diploid Atlantic salmon (Salmosalar L.). J Sci Food Agric 84(6):530-40.

Bourne MC. 1975. Texture measurements in vegetables. In: Rha C, editor. Theory, determination and control of physical properties of food materials. Dordrecht, Netherlands: Reidel Publ. p 131-62.

Bourne M. 2002. Food texture and viscosity: concept and measurement. 2nd ed. New York: Academic Press. 445 p.

Bremner HA. 1992. Fish flesh structure and the role of collagen-Its post mortem aspects and implication for fish processing. In: Huss HH, editor, Quality assurance in the fish industry. Amsterdam: Elsevier. p 39-62.

Busconi L, Folco EJ, Martone CB, Sanchez JJ. 1989. Postmortem changes in cytoskeletal elements of fish muscle. J Food Biochem 13:443-51.

Bugeon J, Lefévre F, Fauconneau B. 2004. Correlated changes in skeletal muscle connective tissue and flesh texture during starvation and re-feeding in brown trout (Salmo trutta) reared in seawater. J Sci Food Agric 84:1433-41.

Dobraszczyk BJ, Vincent JFV. 1999. Measurement of mechanical properties of food materials in relation to texture: the materials approach. In: Rosenthal A, editor. Food texture: measurement and perception. $1^{\text {st }}$ ed. Maryland: Aspen Publishers, Inc. p 99-151.

Dowdy S, Wearden S, Chiko D. 2004. Statistics for research. $3^{\text {rd }}$ ed. Hoboken, NJ: John Wiley \& Sons, Inc. 627 p.

Dunajski E. 1979. Texture of fish muscle. J Texture Stud 10:301-18.

Espe M, Ruohonen K, Bjornevik M, Froyland L, Nortvedt R, Kiessling A. 2004. Interactions between ice storage time, collagen composition, gaping and textural properties in farmed salmon muscle harvested at different times of the year. Aquaculture 240:489-504.

Food Safety Education: Is It Done Yet? [Internet]. Washington, DC: Food Safety and Inspection Service, United States Department of Agriculture; 2006 May 9 [2011 May 19]. Available from: http://www.fsis.usda.gov.

Gomez Guillen MC, Montero P, Hurtado O, Borderías A. 2000. Biological characteristics affect the quality of farmed Atlantic salmon and smoked muscle. J Food Sci 65(1):53-60.

Guinard J-X, Mazzucchelli R. 1996. The sensory perception of texture and mouth-feel. Trends Food Sci. Technol 7:213-9. 
Hagen $\varnothing$, Solberg C, Sirnes E, Johnston IA. 2007. Biochemical and structural factors contributing to seasonal variation in the texture of farmed Atlantic halibut (Hippoglossushippoglossus L.) flesh. J Agric Food Chem 55:5803-8.

Hamann DD. 1988. Rheology as means of evaluating muscle functionality of processed foods. Food Technol 42(6):66-71.

Harris DC. 2007. Quantitative chemical analysis. $7^{\text {th }}$ ed. New York: W.H. Freeman and Company.

Haugen T, Kiessling A, Olsen RE, RØra MB, Slinde E, Nortvedt R. 2006. Seasonal variation in muscle growth dynamics and selected quality attributes in Atlantic halibut (Hippoglossushippoglossus L.) fed dietary lipids containing soybean and/or herring oil under different rearing regimes. Aquaculture 261:565-79.

Howgate P. 1977. Aspects of fish texture. In: Birch GC, Brennan JG, Parker KJ, editors. Sensory properties of foods. London:Applied Science Publishers Ltd. p 249-69.

Hultin HO. 1985. Characteristics of muscle tissue. In: Fennema OR, editor. Food chemistry. New York: Marcel Dekker. p 725-89.

Hyldig G, Nielsen D. 2007. Texture of fish, fish products, and shellfish. In: Nollet LM editor. Handbook of meat, poultry and seafood quality.1st ed. Ames, IA: Blackwell Publishing. p 549-61.

Johnston IA, Strugnell G, McCracken ML, Johnstone R. 1999. Muscle growth and development in normal-sex-ratio and all-female diploid and triploid Atlantic salmon. J Exp Biol 202:1991-2016.

Johnston IA, Li X, Vieira VLA, Nickell D, Dingwall A, Alderson R, Campbell P, Bickerdike R. 2006. Muscle and flesh quality traits in wild and farmed Atlantic salmon. Aquaculture 256:323-36.

Koch RM, Crouse JD, Dikeman ME, Cundiff LV, Gregory KE. 1989. Effects of marbling on sensory panel tenderness in Bos taurus and Bos indicus crosses. J Anim Sci_66:305.

Li X, Bickerdike R, Lindsay E, Campbell P, Nickell D, Dingwall A, Johnston IA. 2005. Hydroxylysylpyridinoline cross-link concentration affects the textural properties of fresh and smoked Atlantic salmon (Salmosalar L.) flesh. J Agric Food Chem 53:6844-50.

Love RM, Yamaguchi K, Creac'h Y Lavety J. 1976. The connective tissues and collagens of cod during starvation. Comp Biochem Physiol 55B:487-92.

Mørkøre T, Einen O. 2003. Relating sensory and instrumental texture analysis of Atlantic salmon. J Food Sci 68(4):1492-97. 
Montero P, Borderías J, Turnay J, Leyzarbe MA. 1990. Characterization of hake (Merluccius merluccius L.) and trout (Salmo irideus) collagen. J Agric Food Chem 38:604-9.

Montero P, Borderías J. 1992. Influence of myofibrillar proteins and collagen aggregation on the texture of frozen hake muscle. In: Huss HH, Jakobsen M, Liston J, editors. Quality Assurance in the Fish Industry. Amsterdam: Elsevier Science Publisher BV. p 149-67.

Nollet LML, Boylston T, Chen F, Coggins PC, Gloria MB, Hyldig G, Kerth CR, McKee LH, Hui YH. 2007. Handbook of meat, poultry and seafood quality. Ames, IA: Blackwell Publishing. 744 p.

Nortvedt R, Tuene S. 1998. Body composition and sensory assessment of three weight groups of Atlantic halibut (Hippoglossushippoglossus) fed three pellet sizes and three dietary fat levels. Aquaculture 161:295-313.

O'Keefe RA, Benfey TJ. 1999. Comparative growth and food consumption of diploid and triploid brook trout (Salvelinus fontinalis) monitored by radiography. Aquaculture 175:111-20.

Purchas RW. 2004. Tenderness measurement. In: Jensen WK, editor. Encyclopedia of meat sciences. Oxford: Elsevier Ltd. p 1370-77.

Ramachandran GN. 1988. Stereochemistry of collagen. J Peptide Prot Res 31:1-16.

Robb DHF, Kestin SC, Warriss PD, Nute GR. 2002. Muscle lipid content determines the eating quality of smoked and cooked Atlantic salmon (Salmosalar). Aquaculture 205:345-58.

SAS Institute Inc. 2004. SAS/STAT ${ }^{\circledR} 9.1$ user's guide, first ed. SAS Publishing, NC.

Sato K, Ohashi C, Ohtsuki K, Kawabata M. 1991. Type V collagen in trout (Salmogairdneri) muscle and its solubility change during chilled storage of muscle. J Agric Food Chem 39:1222-5.

Shigemura Y, Ando M, Tsukamasa Y, Makinodan Y, Kawai T. 2003. Correlation of type V collagen content with post-mortem softening of fish meat during chilled storage. Fisheries Sci 69:842-8.

Sigurgisladottir S, Sigurdardottir MS, Ingvarsdottir H, Torrissen OJ, Hafsteinsson H. 2001. Microstructure and texture of fresh and smoked Atlantic salmon, Salmo salar L., fillets from fish reared and slaughtered under different conditions. Aquac Res 32:1-10.

Sikorski ZE, Scott DN, Buisson DH. 1984. The role of collagen in the quality and processing of fish. CRC Crit Rev Food Sci Nutr 20:301-43.

Solomon MB, Eastridge JS, Paroczay EW, Bowker BC. 2008. Measuring meat texture. In: Nollet LML, Toldra F, editors. Handbook of Muscle Foods Analysis. Boca Raton, FL: CRC Press. p 479-502. 
Taylor RG. 2004. Connective tissue structure, function and influence on meat quality. In: Jensen WK, editor. Encyclopedia of meat sciences. Oxford:Elsevier Ltd. p 306-13.

Veland JO, Torrissen OJ. 1999. The texture of Atlantic salmon (Salmosalar) muscle as measured instrumentally using TPA and Warner-Bratzler shear test. J Sci Food Agric 79:1737-46.

Verrez-Bagnis V. 1997. Post mortem denaturation of fish muscle proteins - changes in some myofibrillar, intermediate filament and costameric proteins. In: Olafsdóttir G, Luten J, Dalgaard P, Careche M, Verrez-Bagnis V, Martinsdóttir E, Heia K, editors. Methods to determine the freshness of fish in research and industry. Paris: International Institute of Refrigeration. p 229-37.

Voisey PW. 1976. Engineering assessment and critique of instruments used for meat tenderness evaluation. J Text Stud 7:11-48.

Young A, Morris PC, Hungerford FA, Sinnott R. 2005. The effects of diet, feeding regime and catch-up growth on flesh quality attributes of large (1+ sea winter) Atlantic salmon, Salmosalar. Aquaculture 248:59-73. 
Table 1 - Comparison of features of variable-blade and Allo-Kramer shear method for testing fillet firmness using the TA.HDi Texture Analyzer ${ }^{1}$.

\begin{tabular}{|c|c|c|}
\hline Method & Variable-Blade & Allo-Kramer \\
\hline Test principle & Shear-cutting & Shear \\
\hline Fixture & $\begin{array}{l}\text { Twelve, } 0.635-\mathrm{mm} \text { thick, } \\
\text { 12.7-mm wide blades } \\
\text { arranged in two rows }\end{array}$ & $\begin{array}{c}\text { Five, } 3.0-\mathrm{mm} \text { thick, } 70-\mathrm{mm} \\
\text { wide blades }\end{array}$ \\
\hline Crosshead speed $\left(\mathrm{mm} \mathrm{min}^{-1}\right)$ & 127 & 127 \\
\hline $\begin{array}{l}\text { Parameter calculated from } \\
\text { force-deformation curve }\end{array}$ & $\begin{array}{l}\text { Maximum force }(\mathrm{g} / \mathrm{g}) \text {, area } \\
\text { under positive curve } \\
\left(\mathrm{g}^{*} \mathrm{~mm}\right)^{2}\end{array}$ & $\begin{array}{l}\text { Maximum force }(\mathrm{g} / \mathrm{g}) \text {, area } \\
\text { under positive curve } \\
\left(\mathrm{g}^{*} \mathrm{~mm}\right)^{2}\end{array}$ \\
\hline Property measured & Firmness & Firmness \\
\hline
\end{tabular}

${ }^{1}$ TA.HDi Setting: Mode: measure force in compression; Option: return to start; Pre-test speed: $5 \mathrm{~mm} / \mathrm{sec}$; Test speed: $2 \mathrm{~mm} / \mathrm{sec}$; Post-test speed: $10 \mathrm{~mm} / \mathrm{sec}$; Distance: $45 \mathrm{~mm}$; Trigger type: button; Data acquisition rate: 200pps.

${ }^{2}$ The area data was recorded starting when the blade touched sample (force $=0 \mathrm{~g}$ ) until the maximum force was achieved. For both attachments, area under force-deformation curve after maximum force was excluded. 
Table 2 - Maximum shear force $(\mathrm{g} / \mathrm{g})$ and energy of shear (area; $\left.\mathrm{g}^{*} \mathrm{~mm}\right)$ determined by variable blade (VB) and Allo-Kramer (AK) attachment, and alkaline-soluble (a-s), alkalineinsoluble (a-i), and total hydroxyproline content (HYP; $\mu$ mole/g) of trout fillet from females harvested at three age endpoints.

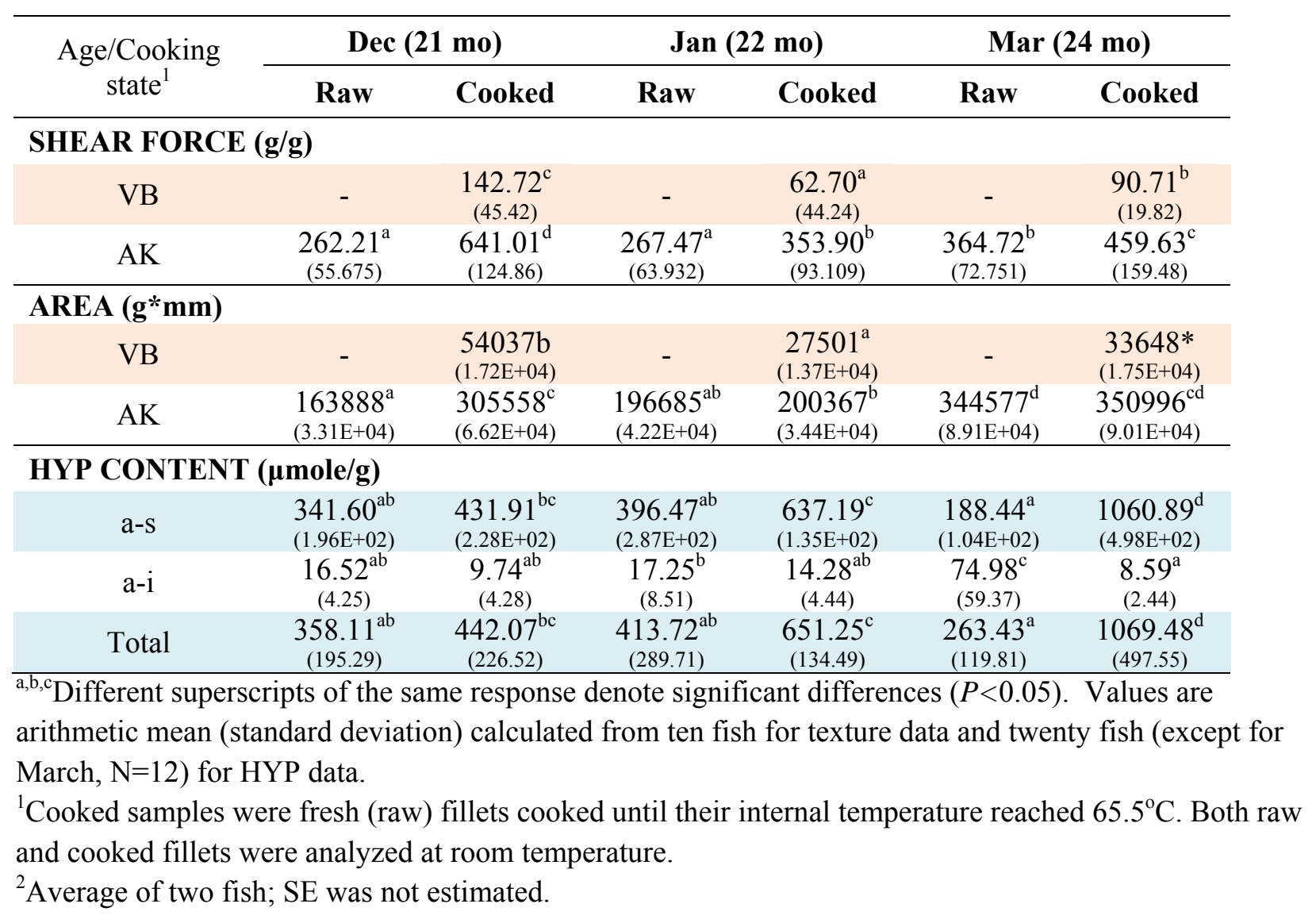


Table 3 - Maximum shear force $(\mathrm{g} / \mathrm{g})$ and energy of shear (area; $\left.\mathrm{g}^{*} \mathrm{~mm}\right)$ determined by variable blade (VB) and Allo-Kramer (AK) attachment, and alkaline-soluble (a-s), alkalineinsoluble (a-i), and total hydroxyproline content (HYP; $\mu \mathrm{mole} / \mathrm{g})$ of raw and cooked fillets received different storage regimens.

\begin{tabular}{|c|c|c|c|c|c|c|c|c|}
\hline \multirow{2}{*}{$\begin{array}{l}\text { Storage } \\
\text { regimen }{ }^{1 /} \\
\text { Cooking } \\
\text { state }^{2}\end{array}$} & \multicolumn{2}{|c|}{$\mathbf{R 3}$} & \multicolumn{2}{|c|}{$\mathbf{R 7}$} & \multicolumn{2}{|c|}{ R3F30 } & \multicolumn{2}{|c|}{ R7F30 } \\
\hline & Raw & Cooked & Raw & Cooked & Raw & Cooked & Raw & Cooked \\
\hline \multicolumn{9}{|c|}{ SHEAR FORCE (g/g) } \\
\hline VB & $\begin{array}{c}123.64^{\mathrm{a}} \\
(38.85)\end{array}$ & $\begin{array}{c}230.82^{b} \\
(24.46)\end{array}$ & $\begin{array}{c}129.53^{\mathrm{a}} \\
(38.56)\end{array}$ & $\begin{array}{c}246.11^{\mathrm{b}} \\
(34.44)\end{array}$ & $\begin{array}{l}79.94^{\mathrm{a}} \\
(28.15)\end{array}$ & $\begin{array}{c}329.12^{\mathrm{c}} \\
(57.61)\end{array}$ & $\begin{array}{c}90.89^{\mathrm{a}} \\
(21.48)\end{array}$ & $\begin{array}{c}279.54^{\mathrm{bc}} \\
(92.65)\end{array}$ \\
\hline $\mathrm{AK}$ & $\begin{array}{c}210.69 \\
(72.63)\end{array}$ & $\begin{array}{c}399.67 \\
(32.71)\end{array}$ & $\begin{array}{c}208.69 \\
(83.35)\end{array}$ & $\begin{array}{c}450.84 \\
(70.39)\end{array}$ & $\begin{array}{c}163.80 \\
(71.17)\end{array}$ & $\begin{array}{l}520.54 \\
(110.03)\end{array}$ & $\begin{array}{c}133.77 \\
(36.17)\end{array}$ & $\begin{array}{c}471.81 \\
(52.81)\end{array}$ \\
\hline \multicolumn{9}{|c|}{$\operatorname{AREA}\left(g^{*} \mathbf{m m}\right)$} \\
\hline VB & $\begin{array}{c}44008 \\
(5.16 \mathrm{E}+03)\end{array}$ & $\begin{array}{c}86788 \\
(1.87 \mathrm{E}+04)\end{array}$ & $\begin{array}{c}44752 \\
(1.27 \mathrm{E}+04)\end{array}$ & $\begin{array}{c}86329 \\
(2.56 \mathrm{E}+04)\end{array}$ & $\begin{array}{c}24283 \\
(3.93 \mathrm{E}+03)\end{array}$ & $\begin{array}{c}101350 \\
(1.52 \mathrm{E}+04)\end{array}$ & $\begin{array}{c}25975 \\
(8.43 \mathrm{E}+03)\end{array}$ & $\begin{array}{c}89536 \\
(1.47 \mathrm{E}+04)\end{array}$ \\
\hline $\mathrm{AK}$ & $\begin{array}{l}104421^{b} \\
(1.53 \mathrm{E}+04)\end{array}$ & $\begin{array}{l}142805^{\mathrm{c}} \\
(1.30 \mathrm{E}+04)\end{array}$ & $\begin{array}{l}109137^{b} \\
(2.57 E+04)\end{array}$ & $\begin{array}{l}159112^{c} \\
(3.24 E+04)\end{array}$ & $\begin{array}{c}62167^{\mathrm{a}} \\
(1.41 \mathrm{E}+04)\end{array}$ & $\begin{array}{l}168122^{c} \\
(3.25 \mathrm{E}+04)\end{array}$ & $\begin{array}{c}52739^{\mathrm{a}} \\
(6.67 \mathrm{E}+03)\end{array}$ & $\begin{array}{l}139789^{c} \\
(1.62 \mathrm{E}+04)\end{array}$ \\
\hline \multicolumn{9}{|c|}{ HYP CONTENT ( $\mu \mathrm{mole} / \mathrm{g})$} \\
\hline a-s & $\begin{array}{c}1455.86 \\
(572.78)\end{array}$ & $\begin{array}{c}1919.79 \\
(1050.1)\end{array}$ & $\begin{array}{c}1361.11 \\
(677.93)\end{array}$ & $\begin{array}{c}1929.36 \\
(1173.59)\end{array}$ & $\begin{array}{c}1541.01 \\
(543.98)\end{array}$ & $\begin{array}{c}3318.60 \\
(1790.9)\end{array}$ & $\begin{array}{c}2401.43 \\
(2012.48)\end{array}$ & $\begin{array}{c}2645.58 \\
(1969.75)\end{array}$ \\
\hline$a-i$ & $\begin{array}{c}93 \\
(61.59)\end{array}$ & $\begin{array}{l}85.61 \\
(90.42)\end{array}$ & $\begin{array}{l}89.09 \\
(83.85)\end{array}$ & $\begin{array}{c}106.71 \\
(82.91)\end{array}$ & $\begin{array}{c}131.50 \\
(64.08)\end{array}$ & $\begin{array}{l}90.55 \\
(59.59)\end{array}$ & $\begin{array}{l}92.69 \\
(79.63)\end{array}$ & $\begin{array}{l}80.57 \\
(61.43)\end{array}$ \\
\hline Total & $\begin{array}{c}1548.86 \\
(595.73)\end{array}$ & $\begin{array}{c}2005.39 \\
(1024.51)\end{array}$ & $\begin{array}{c}1450.19 \\
(715.83)\end{array}$ & $\begin{array}{c}2036.07 \\
(1168.27)\end{array}$ & $\begin{array}{c}1672.52 \\
(577.38)\end{array}$ & $\begin{array}{c}3409.15 \\
(1802.09)\end{array}$ & $\begin{array}{c}2494.12 \\
(2035.8)\end{array}$ & $\begin{array}{r}2726.15 \\
(1967.28)\end{array}$ \\
\hline
\end{tabular}

${ }^{a, b, c}$ Different superscripts of the same response denote significant differences $(P<0.05)$. Values are arithmetic mean (standard deviation) calculated from six fish for texture data and nine fish for HYP data. ${ }^{1} \mathrm{R} 3$ : refrigeration at $2^{\circ} \mathrm{C}$ for 3 days; $\mathrm{R} 7$ : refrigeration for 7 days; $\mathrm{R} 3 \mathrm{~F} 30$ : refrigeration for 3 days followed by frozen storage at $-25^{\circ} \mathrm{C}$ for 30 days; R7F30: refrigeration for 7 days followed by frozen storage for 30 days.

${ }^{2}$ Cooked samples were fresh (raw) fillets cooked until their internal temperature reached $65.5^{\circ} \mathrm{C}$. Both raw and cooked fillets were analyzed at room temperature. 
Table 4 - Pearson correlation coefficient (r) between alkaline-insoluble hydroxyproline (a-i HYP) content and instrumental texture parameter form variable blade (VB) and AlloKramer (AK) attachment.

\begin{tabular}{|c|c|c|c|c|c|}
\hline \multirow{2}{*}{ Attachment } & \multirow{2}{*}{ Parameter } & \multicolumn{2}{|c|}{ Raw } & \multicolumn{2}{|c|}{ Cooked } \\
\hline & & $\mathrm{r}$ & $\mathrm{P}$ & $\mathrm{r}$ & $\mathrm{P}$ \\
\hline \multicolumn{6}{|c|}{ Maturation study } \\
\hline \multirow[t]{2}{*}{ VB } & Shear force & - & - & 0.08 & n.s. \\
\hline & Energy of shear & - & - & 0.05 & n.s. \\
\hline \multirow[t]{2}{*}{$\mathrm{AK}$} & Shear force & 0.57 & $<0.0001$ & -0.24 & n.s. \\
\hline & Energy of shear & 0.47 & 0.0003 & -0.29 & n.s. \\
\hline \multicolumn{6}{|c|}{ Storage regimen study } \\
\hline \multirow[t]{2}{*}{$\mathrm{VB}$} & Shear force & -0.38 & n.s. & 0.21 & n.s. \\
\hline & Energy of shear & -0.08 & n.s. & 0.09 & n.s. \\
\hline \multirow[t]{2}{*}{ AK } & Shear force & 0.01 & n.s. & 0.01 & n.s. \\
\hline & Energy of shear & 0.13 & n.s. & 0.12 & n.s. \\
\hline
\end{tabular}

n.s. $=$ not significant $(\mathrm{P}>0.05) . \mathrm{n}=60$ (maturation study) and 12 (storage regimen study). 


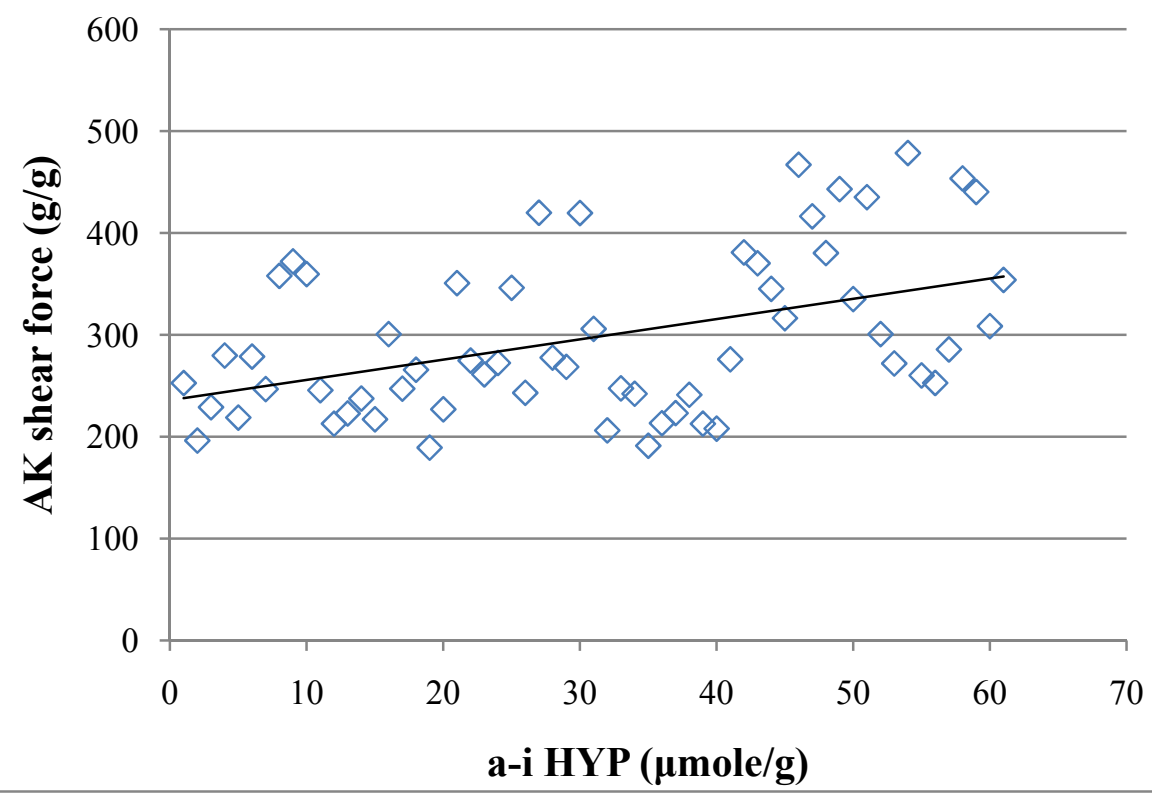

Figure 1 - The relationship between alkaline-insoluble hydroxyproline (a-i HYP) content and shear force of raw fillet determined by Allo-Kramer shear attachment (AK). Firstorder linear regression was fitted to the data with the following equation: shear force $=$ $253.28+1.15(\mathrm{a}-\mathrm{i} H Y P) ; \mathrm{R}^{2}=0.32 ; \mathrm{n}=60 ; \mathrm{P}<0.0001$. 


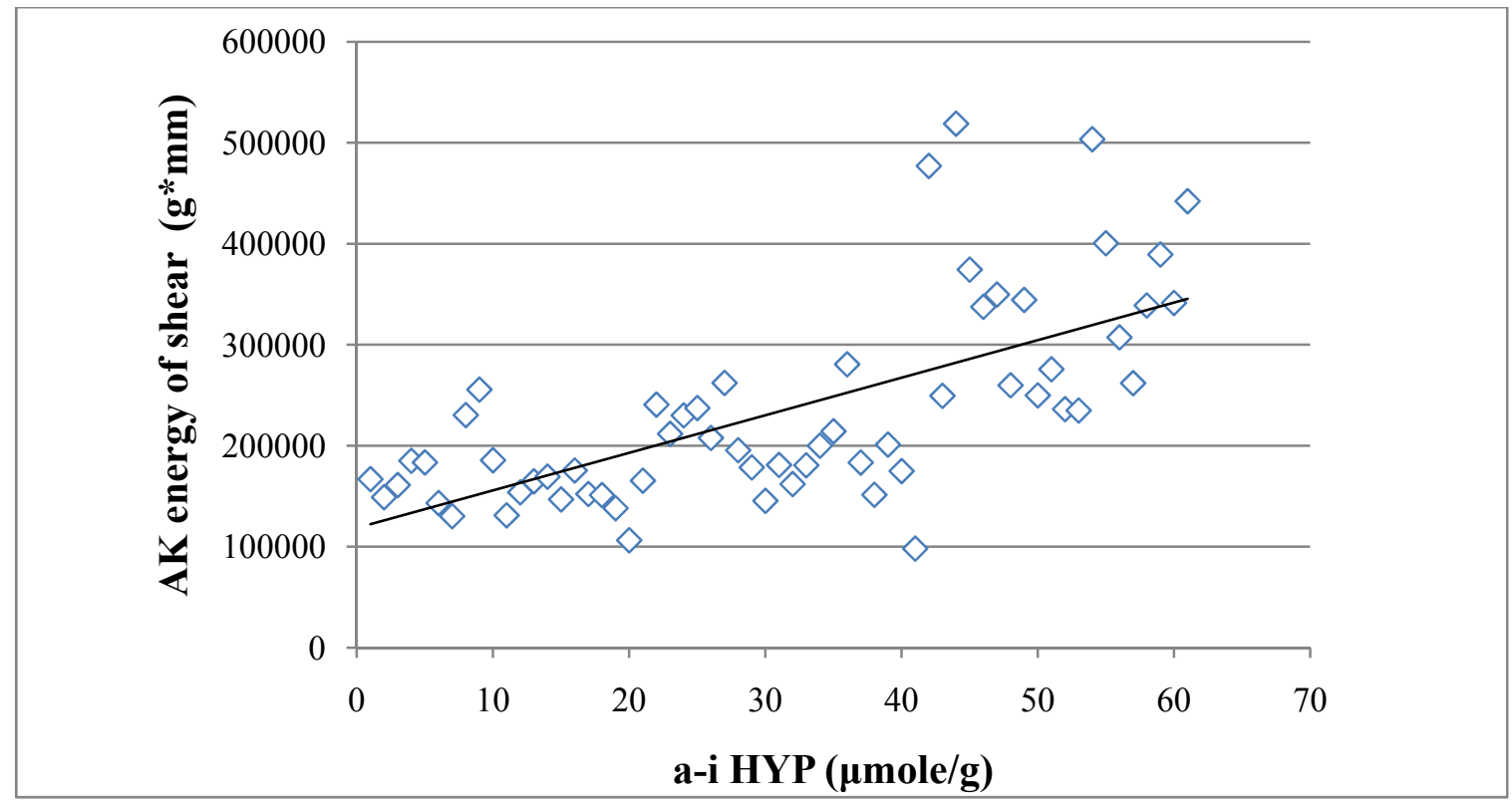

Figure 2 - The relationship between alkaline-insoluble hydroxyproline (a-i HYP) content and energy of shear of raw fillet determined by Allo-Kramer shear attachment (AK). First-order linear regression was fitted to the data with the following equation: energy of shear $=183012.06+1098.98(a-i$ HYP $) ; R^{2}=0.22 ; n=60 ; P=0.0003$. 


\section{OVERALL SUMMARY AND FUTURE RESEARCH}

Based on the results reported in this dissertation, we concluded that fillet composition affected variation in fillet texture and sensitivity of the shearing device. Muscle fat lubricated and softened fillets; whereas, collagen cross-link strengthened fillet structure. Texture determined by variable-blade (VB) attachment did not relate to collagen content and solubility; however, in analysis of cooked fillet texture, the VB attachment was less destructive and improved accuracy of shear test.

In future studies, it is necessary to determine concentration of mature hydroxylysyl pyridinoline cross-links (PYD) in muscle, especially in the model that determines effect of maturation and season on raw fillet texture. In addition, water holding capacity (liquid loss) can be used as an index of structural change to fillet structure due to the degradation or denaturation of myofibrillar proteins. Further investigations are required to compare shear test with other instrumental method such as compression and tensile tests using different kinds of attachment (e.g., cylindrical probe, spiked blocks, etc.) to obtain different texture parameters such as springiness, cohesiveness, and deformability. Different deformation mechanisms and test parameters represent different kinds of contributors to changes in fillet texture and therefore can fully describe this multiple-quality parameter. Finally, growth and fillet quality traits should be related to gene expression patterns to identify genetic markers for muscle growth and fillet firmness traits in trout. 


\section{CURRICURRUM VITAE}

\section{$\underline{\text { EDUCATION }}$}

Ph.D. in Animal and Food Sciences (August 2011)

West Virginia University, U.S.A.

M.Sc. in Food and Nutrition for Development (May 2004)

Mahidol University, Thailand

B.Sc. in Food Technology (May 2000)

Chulalongkorn University, Thailand

\section{HONORS \& AWARDS}

- $1^{\text {st }}$ Place Winner, Video Contest for Texture Analysis (June 2009)

Texture Technologies Corp., IFT Annual Meeting

(http://www.youtube.com/watch?v=Xydu-1d0adI)

- Travel Award, Poster Presentation (June 2009, July 2010)

Texture Technologies Corp., IFT Annual Meeting

- $3^{\text {rd }}$ Place Winner, Ph.D. Poster Section (April 2008)

Davis College Graduate Student Conference, West Virginia University

\section{RESEARCH SKILLS}

- Texture analysis: instrumental (Texture Analyzer) and descriptive sensory test

- Hydroxyproline quantification: high performance liquid chromatography

- Protein denaturation: differential scanning calorimetry

- Rheological/gelling properties: dynamic rheological test

- Proximate composition

- Quantitative data analysis: ANOVA, MANOVA, correlation, regression, and principal component analysis using SAS and SPSS program

\section{SELECETED PUbliCATIONS}

Aussanasuwannakul, A, P. Kenney, G. Weber, J. Yao, S. Slider, M. Manor, and M. Salem. 2011. Effect of sexual maturation on growth, fillet composition, and texture of female rainbow trout (Oncorhynchus mykiss) on a high nutritional plane, Aquaculture 317:79-88.

Aussanasuwannakul, A, P. Kenney, R. Brannan, S. Slider, M. Salem, and J. Yao. 2010. Relating instrumental texture, determined by variable-blade and Allo-Kramer shear attachments, to sensory analysis of rainbow trout, Oncorhynchus mykiss, fillets. Journal of Food Science 75(7):S365-74. 